\title{
Department of Homeland Security, Science and Technology Directorate, Borders and Maritime Security Division: Renewable Energy Research Roadmap
}

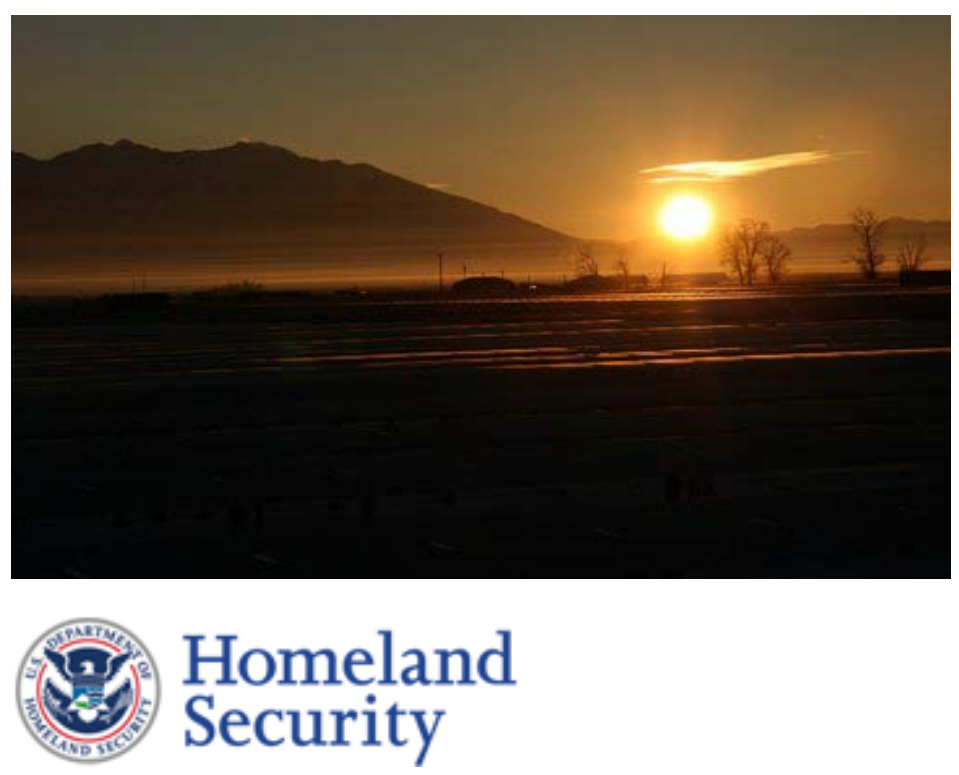

Produced under direction of the U.S. Department of Homeland Security, Science and Technology Directorate, Borders and Maritime Security Division by the National Renewable Energy Laboratory (NREL) under Interagency Agreement IAG-09-1727 and Task No. WFB9.2000 


\section{Department of Homeland Security, Science and Technology Directorate, Borders and Maritime Security Division: Renewable Energy Research Roadmap}

\section{Alicen Kandt and Scott Huffman}

\begin{abstract}
Disclaimer: This manuscript has been authored by employees of the Alliance for Sustainable Energy, LLC ("Alliance") under Contract No. DE-AC3608GO28308 with the U.S. Department of Energy ("DOE"). The tables and figures in this report are limited to use in this report only and are not to be further disseminated or used without the permission of the sources cited.

Neither Alliance, DOE, the United States government nor any agency thereof, nor any of their employees, makes any warranty, express or implied, or assumes any legal liability or responsibility for the accuracy, completeness, or usefulness of any information, apparatus, product, or process disclosed in this manuscript, or represents that its use would not infringe privately owned rights. Reference herein to any specific commercial product, process, or service by trade name, trademark, manufacturer, or otherwise does not necessarily constitute or imply its endorsement, recommendation, or favoring by Alliance, DOE or the United States Government or any agency thereof. The views and opinions of authors expressed herein do not necessarily state or reflect those of Alliance, DOE or the United States government or any agency thereof.
\end{abstract}

Cover photo by Steve Wilcox, NREL PIX/15551

NREL is a national laboratory of the U.S. Department of Energy, Office of Energy Efficiency \& Renewable Energy, operated by the Alliance for Sustainable Energy, LLC. Contract No. DE-AC36-08G028308
National Renewable Energy Laboratory 1617 Cole Boulevard, Golden, Colorado 80401 303-275-3000 • www.nrel.gov

\section{Technical Report}

NREL/TP-7A40-51491

July 2011 


\section{Contacts}

National Renewable Energy Laboratory

Alicen Kandt

Senior Engineer

1617 Cole Boulevard

Golden, CO 80401

Phone: 303-384-7518

E-mail: alicen.kandt@,nrel.gov

Scott Huffman

Senior Engineer

1617 Cole Boulevard

Golden, CO 80401

Phone: 303-275-4384

E-mail: scott.huffman@nrel.gov

\section{Department of Homeland Security}

\section{Jeanne Lin}

Deputy Director, HSARPA/Borders and

Maritime Security Division, Science and

Technology Directorate,

Department of Homeland Security

Washington, DC 20528

Phone: 202-254-5737

E-mail: jeanne.lin@dhs.gov 


\section{Acknowledgements}

The National Renewable Energy Laboratory (NREL) staff gratefully acknowledges the numerous NREL researchers who contributed to this report, including: Robert Thresher (marine hydrokinetic); Robi Robichaud (wind); Lin Simpson (batteries); Melanie Caton, Michael Penev, Huyen Dinh, Keith Wipke, John Lewis, and Chris Ainscough (fuel cells and hydrogen); Philip Pienkos and Jianping Yu (algae biomass); and Phillip Parilla (energy transfer). Andrea Watson and Heidi Blakley also contributed to the report review and compilation process.

The NREL staff wishes to acknowledge U.S. Department of Homeland Security (DHS) staff for support in coordinating site visits and data gathering, especially John Contreras (U.S. Customs and Border Protection [CBP] El Paso Sector), Sudie Hargis (U.S. Coast Guard [USCG] Alaska), and Merv Leavitt (CBP headquarters). 


\section{List of Acronyms and Abbreviations}

$\begin{array}{ll}\text { A } & \text { amp } \\ \text { AC } & \text { alternating current } \\ \text { AMFC } & \text { alkaline membrane fuel cell } \\ \text { ARPA-E } & \text { Advanced Research Projects Agency-Energy } \\ \text { BAU } & \text { business as usual } \\ \text { BES } & \text { Basic Energy Science } \\ \text { BMD } & \text { Borders and Maritime Security Division } \\ \text { CBP } & \text { U.S. Customs and Border Protection } \\ \text { CERDEC } & \text { Communications-Electronics Research, Development and } \\ \text { CHP } & \text { Engineering Center } \\ \text { CIGS } & \text { combined heat and power } \\ \text { DARPA } & \text { copper, indium, gallium, selenide } \\ \text { DC } & \text { Defense Advanced Research Project Agency } \\ \text { DMFC } & \text { direct current } \\ \text { DOE } & \text { direct methanol fuel cells } \\ \text { DOD } & \text { U.S. Department of Energy } \\ \text { DHS } & \text { U.S. Department of Defense } \\ \text { EE } & \text { U.S. Department of Homeland Security } \\ \text { EERE } & \text { Energy Efficiency } \\ \text { EM } & \text { DOE Office of Energy Efficiency and Renewable Energy } \\ \text { FAD } & \text { electromagnetic } \\ \text { FOB } & \text { fish aggregating device } \\ \text { g/mol } & \text { forward operating base } \\ \text { GHG } & \text { grams per mole } \\ \text { GW } & \text { greenhouse gas } \\ \text { HAWT } & \text { gigawatt } \\ \text { ICE } & \text { horizontal axis wind turbine } \\ \text { IEA-OES } & \text { U.S. Immigration and Customs Enforcement } \\ & \text { International Energy Agency's Ocean Energy Systems } \\ \text { IEC } & \text { Implementing Agreement } \\ \text { kW } & \text { International Electrochemical Commission } \\ \text { kWh } & \text { kilowatt } \\ \text { kW/m } & \text { kilowatt-hour } \\ \text { LCC } & \text { kilowatts per square meter } \\ \text { LED } & \text { life cycle cost } \\ \text { Li } & \text { light-emitting diode } \\ \text { Li-air } & \text { lithium } \\ \text { LiFePO4 } & \text { lithium-air } \\ \text { Li-ion } & \text { lithium iron phosphate } \\ \text { LiPON } & \text { lithium-ion } \\ \text { Li-S } & \text { lithium phosphorous oxynitride } \\ \text { MHK } & \text { lithium-sulfur } \\ \text { MSS } & \text { marine hydrokinetic } \\ & \text { mobile surveillance system } \\ & \end{array}$




$\begin{array}{ll}\text { MW } & \text { megawatt } \\ \text { NASA } & \text { National Aeronautics and Space Administration } \\ \text { NOx } & \text { nitrogen oxide } \\ \text { NREL } & \text { National Renewable Energy Laboratory } \\ \text { O\&M } & \text { Operations \& Maintenance } \\ \text { ORPC } & \text { Ocean Renewable Power Company } \\ \text { OTEC } & \text { thermal energy gradient } \\ \text { PEMFC } & \text { proton-exchange membrane fuel cells } \\ \text { POC } & \text { point of contact } \\ \text { PV } & \text { photovoltaic } \\ \text { R\&D } & \text { research and development } \\ \text { R-21 } & \text { Rescue-21 } \\ \text { RE } & \text { Renewable Energy } \\ \text { RFID } & \text { radio frequency identification } \\ \text { RFP } & \text { request for proposal } \\ \text { rpm } & \text { rotations per minute } \\ \text { RVSS } & \text { remote video surveillance system } \\ \text { S\&T } & \text { Science and Technology Directorate } \\ \text { SBI } & \text { Secure Border Initiative } \\ \text { SOFC } & \text { solid oxide fuel cell } \\ \text { TAG } & \text { triacylglyceride } \\ \text { TI } & \text { turbulence intensity } \\ \text { TSA } & \text { Transportation Security Administration } \\ \text { TSR } & \text { tip speed ratio } \\ \text { TWh/yr } & \text { terawatt-hours per year } \\ \text { USABC } & \text { U.S. Advanced Battery Consortium } \\ \text { USCG } & \text { U.S. Coast Guard } \\ \text { USCIS } & \text { U.S. Citizenship and Immigration Services } \\ \text { V } & \text { volt } \\ \text { VAWT } & \text { vertical axis wind turbine } \\ \text { W } & \text { watt } \\ \text { Wh/kg } & \text { watt-hour per kilogram } \\ \text { Wh/L } & \text { watt-hour per liter } \\ & \end{array}$




\section{Executive Summary}

Within the U.S. Department of Homeland Security (DHS) Science and Technology (S\&T) Directorate, the Borders and Maritime Security Division (BMD) develops and transitions technologies that help enhance the security of our nation's borders and waterways without impeding the flow of commerce and travelers. BMD is identifying next-generation renewableenergy solutions for inclusion in its research portfolio. Recognizing the potential of renewable energy to contribute to border security, BMD partnered with the U.S. Department of Energy (DOE) National Renewable Energy Laboratory (NREL) to examine border-security energy demands and to ensure that advances in renewable energy and energy storage lead to increased security in these areas. This research effort is funded by BMD and is a product of a 2-year interagency agreement between DHS S\&T and DOE. NREL is a national laboratory of the DOE Office of Energy Efficiency \& Renewable Energy (EERE), operated by the Alliance for Sustainable Energy, LLC.

NREL has examined the energy needs along U.S. borders - especially in remote areas - to identify opportunities to apply renewable energy solutions today and to define the near- and long-term research agendas that will position border components and activities to take advantage of renewable energy technologies in the future. This report is a result of those efforts.

This report provides a summary of the work that BMD and NREL have performed to date. It provides an overview of renewable energy technologies that have applicability to DHS security operations, and highlights opportunities for future technology pilot projects or research initiatives that can supplement current technologies by developing solutions for DHS borders and maritime security operational needs. The research roadmap shown in Figure 1 illustrates these renewable energy pilot projects on a short-, mid-, and long-term timeline. 


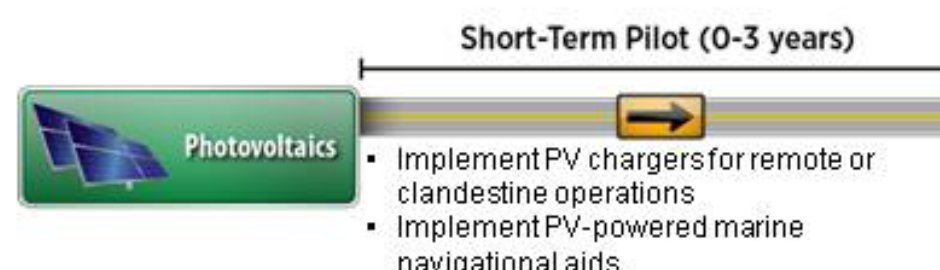

navigational aids

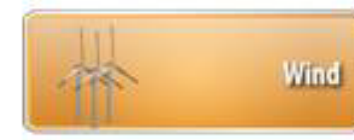

$\longrightarrow$

Test wind turbines for survivability in harsh and extreme environments

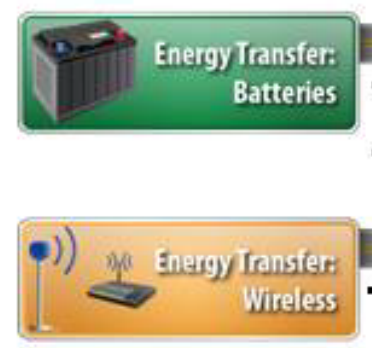

- Evaluate battery cost and durability for handheld or remote equipment

- Combine batteries with supercapacitors or advanced secondary batteries

- Install PV-powered portable LED towers on the southern U.S. border

- Markwater boundaries in Alaska with PV and battery-powered lasers
- Camouflage PV for clandestine operations

- Install concentrated solar power units to

beam power to drones along the southern U.S. border $\longrightarrow$

- Implement a multi-year wind turbine field - Implement a defrosting unit for wind turbines test, build incrementally on successes and failures to achieve ruggedized survivability in extreme winter environments

\section{$\longrightarrow$}

- Test battery-integrated renewable energy - Implement drone batteries that can be storage forlighting tracking sustems, communications, and boundary markers installations
- Power seismic sensorswirelessly using deep ground and surface temperature differential
- Research and implement vehicleswith on-board rectennas that charge seismic sensors by driving the vehicle nearby
- Research micro-electromagnetic transmitters and receiversfor drones that transmit power to buried devices or relay communications signals

\section{Extergy Iransfer:
Fuel Cells}

- Identify fuel cellsfor backup and portable power, as well as remote power stations - Pilot direct methanol and alkaline membrane fuel cells for handheld devices

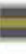

- Pilotfuel cells that charge remote power equipment, such as remote mountaintop communications equipment

\section{-}

Research durable, high-temperature membranes and non-precious catalystsfor alkaline membrane fuel cells

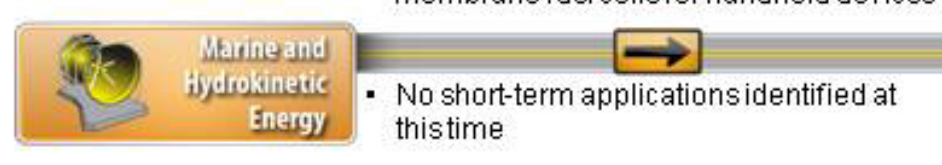
thistime

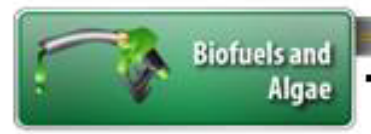

No short-term applicationsidentified at this time

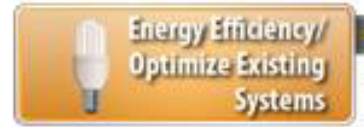

- Improve efficiency of electronic devices - Apply a low-drag coating to reduce the frictional drag of ships

\section{$\longrightarrow$ \\ - Implement power generators for offshore} and river applications, generate reliable energy from renewable sources that do not require fuel or frequent maintenance

\section{$\rightarrow$}

- Grow duckweed algae at remote installations, anaerobically digest for biogas production, grow macroalgae in sheltered ocean waters for food and fuel

- Develop bottom-mounted ocean platforms with acoustic sensorsto track ocean traffic - Develop an unmanned vehicle powered by ocean waves to patrol ocean regions

- Retrofit a ship to havest wild macroalgae and aquatic plants that can be digested on board, providing fuel to power ship systems

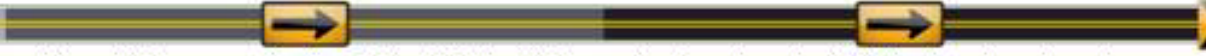
time the frictional drag of ships

Figure 1. DHS renewable energy roadmap outlining potential research opportunities. Illustration by Joshua Bauer, NREL 


\section{Table of Contents}

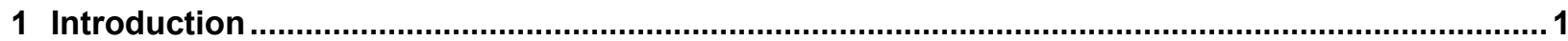

1.1 Overview: Department of Homeland Security Science and Technology Directorate, Borders and Maritime Security Division.... 1

1.2 Renewable Energy Research Roadmap: Project Overview ...............................................

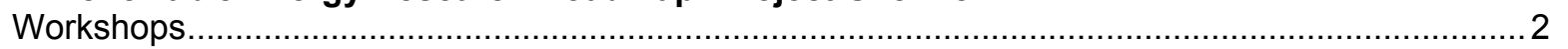

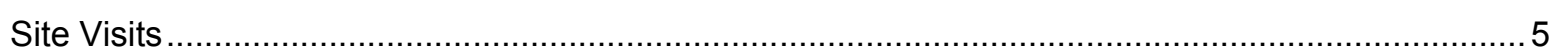

2 Renewable Energy Research and Technology Opportunities .................................................... 6

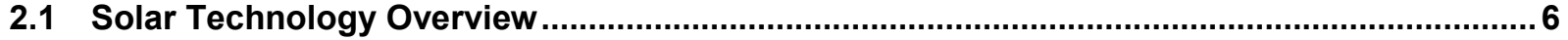

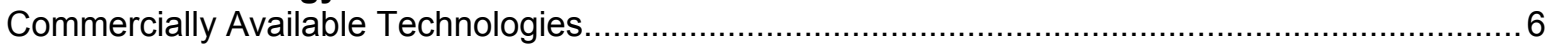

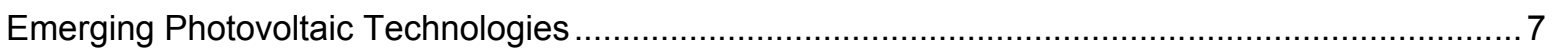

Department of Homeland Security Relevance: Photovoltaic Applications ..................................... 7

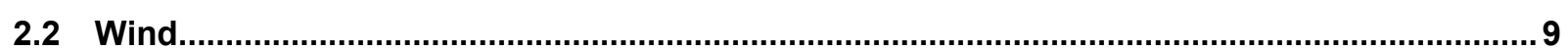

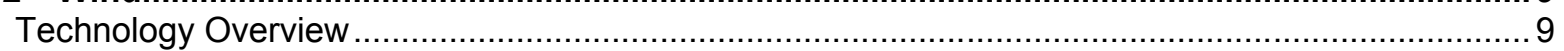

Commercially Available Technologies_Current/Future Research Trends................................... 10

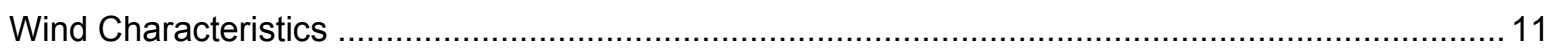

Department of Homeland Security Relevance: Options for Powering Remote

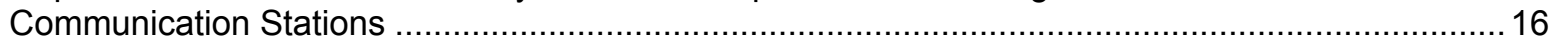

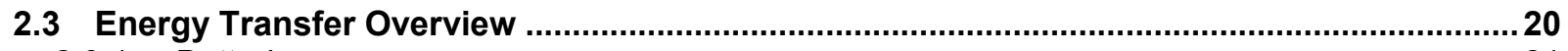

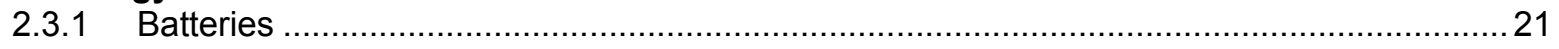

Department of Homeland Security Relevance: Battery Development .......................................... 23

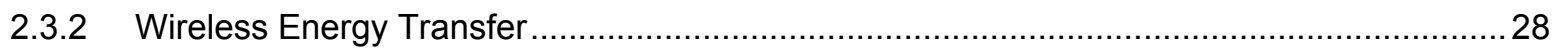

Rectenna Energy Transfer-Technology Overview............................................................. 28

Department of Homeland Security Relevance: Wireless Energy Transfer .....................................29

Inductive Coupling Energy Transfer-Technology Overview ..................................................... 30

Department of Homeland Security Relevance: Inductive Coupling Energy Transfer ...................... 30

Laser Energy Transfer-Technology Overview ...................................................................... 30

Department of Homeland Security Relevance: Laser Energy Transfer ........................................ 30

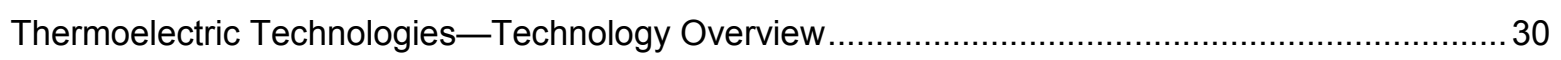

Department of Homeland Security Relevance: Thermoelectric Technologies ............................... 31

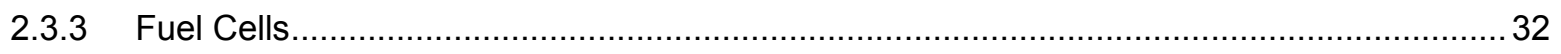

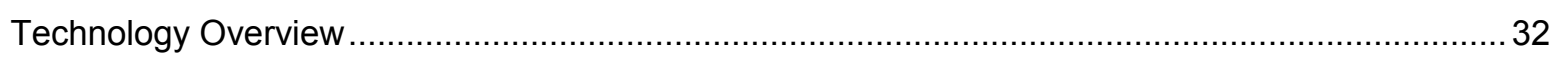

Department of Homeland Security Relevance: Fuel Cell Applications ............................................ 36

2.4 Marine and Hydrokinetic Energy Technologies................................................................. 39

Marine Hydrokinetic Energy Technologies Overview............................................................... 39

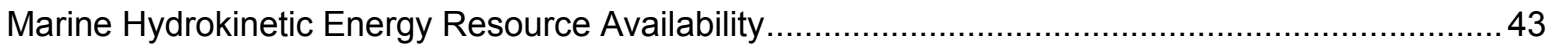

Marine Hydrokinetic Energy Technologies Global Deployment ................................................. 45

Roadmap to Address Commercial Pathway and Challenges for Marine

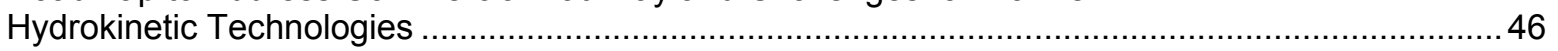

Department of Homeland Security Relevance: Marine Hydrokinetic Energy .................................56

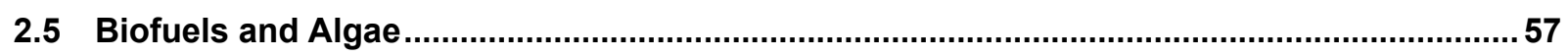

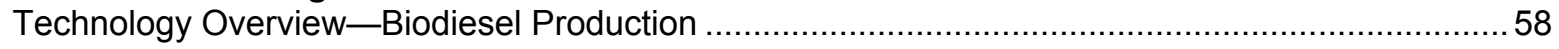


Department of Homeland Security Relevance: Biofuel and Algae Applications .

2.6 Energy Efficiency-Opportunities for Systemic Optimization of Existing and Future Systems.

Department of Homeland Security Relevance: Optimize Existing Systems .................................. 64

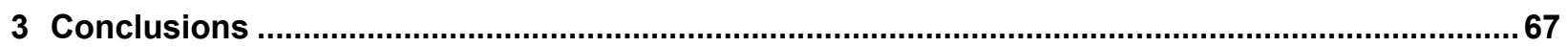

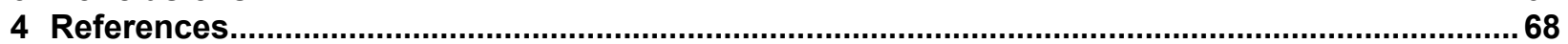

Appendix A. Department of Homeland Security Workshops and Site Visits ................................71

March 19, 2010 (Washington, DC): Introductory Workshop...........................................................71

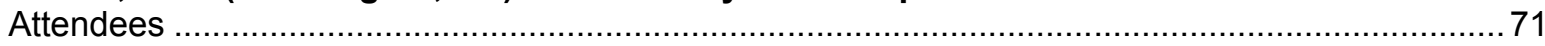

June 21, 2010 (Washington, DC): Data Gathering and Application Prioritization Workshop

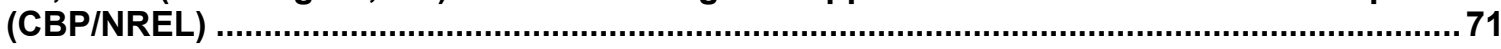

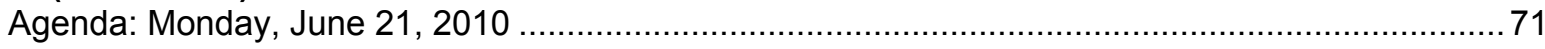

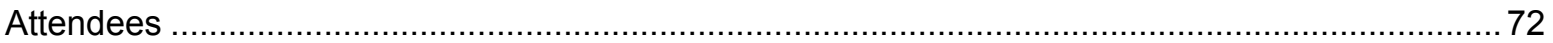

June 21, 2010 (Washington, DC): Data Gathering and Application Prioritization Workshop

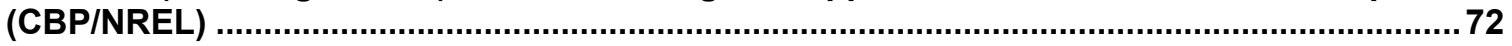

July 22-23, 2010 (Bellingham, WA): Northwest Border Low-Flier Workshop ................................73

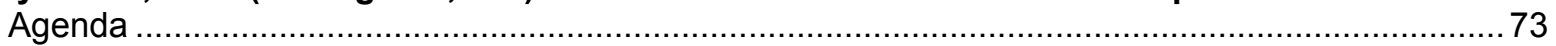

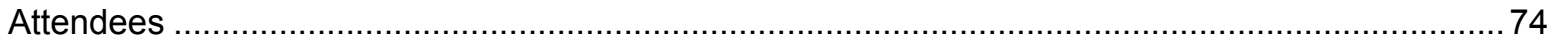

October 26-29, 2010 (EI Paso, TX): El Paso Sector ...................................................................... 74

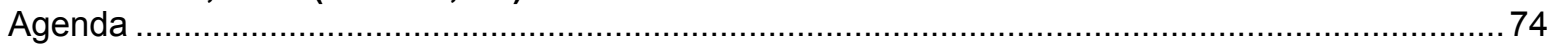

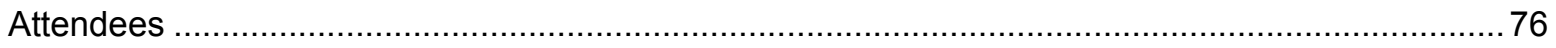

April 5-9, 2011 (Juneau, AK): AK USCG Operations ….........................................................76

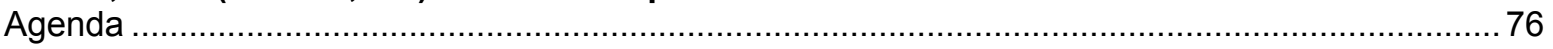

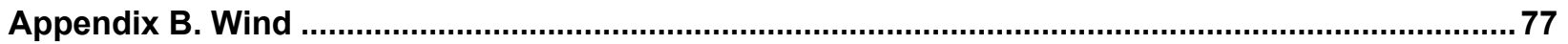

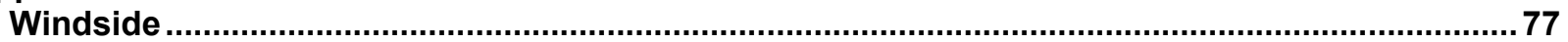

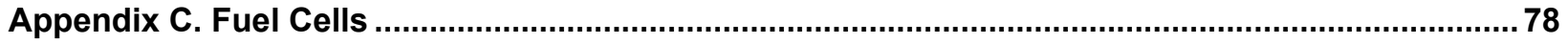




\section{List of Figures}

Figure 1. DHS renewable energy roadmap outlining potential research opportunities. Illustration by Joshua Bauer, NREL

Figure 2. Various types of horizontal and vertical access wind turbines. Illustration by Al Hicks, NREL

Figure 3. Comparison of aerodynamic efficiencies of common types of wind turbines (based on Hau 2000). Illustration by NREL

Figure 4. Proven 11 downwind turbine with spring-loaded blade furling design. Photo from

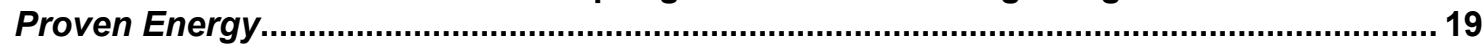

Figure 5. Fuel cell types, fuels, and applications. Illustration from DOE ........................................ 32

Figure 6. Fuel cell basics. Illustration from DOE .......................................................................... 33

Figure 7. Marine hydrokinetic technologies in development worldwide (Khan and Bhuyan 2009) . 40

Figure 8. Five typical wave-energy conversion devices (adapted from Bedard 2006). IIlustration by NREL

Figure 9. Four typical kinetic-energy conversion devices for tidal, ocean, and river currents (adapted from Bedard 2006). Illustration by NREL

Figure 10. Total natural tidal-current energy and wave energy resources in United States; $A$ : Alaska current, B: California current, C: Florida current, D: Gulf Stream, E: Labrador current (adapted from Bedard 2008). Illustration by NREL

Figure 11. Global installed capacity of ocean energy technologies (IEA-OES 2010)

Figure 12. Development and deployment harmonized with the commercial strategy (Thresher 2010)

Figure 13. Marine hydrokinetic development and deployment scenario and the overall R\&D technical strategy (Thresher 2010)

Figure 14. Ocean Power Technologies PowerBuoy wave generation system uses a "smart", oceangoing buoy to capture and convert wave energy into low-cost clean electricity. Photo from Ocean Power Technologies, NREL/PIX 17114

Figure 15. ORPC's Beta Turbine Generator Unit generates clean, renewable electricity by harnessing the energy of the world's rivers and oceans. Photo from Ocean Renewable Power Company, NREL/PIX 17210.

Figure 16. OpenHydro's Open-Center Turbine is designed to be deployed directly on the seabed. The first 6-m test unit produces enough energy to supply 150 average European homes and save the emission of over 450 tons of $\mathrm{CO}_{2}$ greenhouse gas per year. Photo from OpenHydro, NREL/PIX 17243.

Figure 17. Biopower production using algal biomass. Illustration by NREL.

Figure 18. Biochemical strategies for converting algal feedstock into biofuels. Illustration from Sustainable Algal Biofuels Consortium

\section{List of Tables}

Table 1. Comparison of Typical Energy-Storage and Delivery Systems ......................................... 22 Table 2. Comparison of Fuel Cell Technologies (DOE 2011).............................................................. 34 Table 3. Summary of Currently Available Estimates for Wave and Current Energy Resources ...... 45 Table 4. Estimated Capital Costs for Marine Hydrokinetic Wave and Tidal Technologies in 2006 .. 52 Table 5. Power Output at Various Wind Speeds for Windside Turbine Models ................................ 77

Table 6. Power Curves for Proven 11 Wind Turbine ....................................................................... 77 


\section{Introduction}

\subsection{Overview: Department of Homeland Security Science and Technology Directorate, Borders and Maritime Security Division}

Within the U.S. Department of Homeland Security's (DHS) Science and Technology (S\&T) Directorate, the Borders and Maritime Security Division (BMD) develops and transitions technologies that help enhance the security of our nation's borders and waterways without impeding the flow of commerce and travelers. This mission is carried out by technical professionals responsible for funding, managing, developing, prototyping, testing, and evaluating technical solutions for air, land, and maritime borders along with cargo security. BMD's primary end users are operating components within DHS, such as Customs and Border Protection (CBP), Immigration and Customs Enforcement (ICE), U.S. Citizenship and Immigration Services (USCIS), U.S. Coast Guard (USCG), and Transportation Security Administration (TSA) (Jennings et al 2010).

The S\&T Directorate works to cooperate and collaborate amongst the divisions within the Directorate, including BMD. To ensure that efforts undertaken by BMD are aligned with the overarching mission of DHS S\&T, BMD is developing a division-level strategic plan (Jennings et al 2010). As a part of this plan, BMD is in the process of identifying next-generation renewable energy solutions that meet its mission and can be included in its research portfolio. Recognizing the potential of renewable energy to contribute to border security, BMD partnered with the U.S. Department of Energy (DOE) National Renewable Energy Laboratory (NREL) to examine border security energy demands, and to ensure that advances in renewable energy and energy storage lead to increased security in these areas. This research effort is funded by BMD, and this report is a product of a 2-year interagency agreement between DHS S\&T and DOE. NREL is a national laboratory of the DOE Office of Energy Efficiency and Renewable Energy (EERE), operated by the Alliance for Sustainable Energy, LLC.

\subsection{Renewable Energy Research Roadmap: Project Overview}

Renewable energy technologies include solar photovoltaics (PV), wind energy, geothermal, hydrokinetic energy, and biomass. Fuel cells - another important technology — use hydrogen to create energy. Renewable energy technologies have many characteristics that make them particularly useful for increased border security, including the following.

- Continuity of Operations. In the event of grid failure, on-site renewable energy installations can continue to operate, maintaining critical loads until grid service can be restored. The greater the utilization of renewable energy technologies, the longer operations can run without grid power.

- Remote Operation. A renewable energy technology combined with energy storage can operate independent of the electricity grid in remote locations, often requiring very little maintenance to provide service. This can enable new capabilities in remote border-security operations.

- Covert Operation. Some renewable energy technologies (such as PV) operate silently and require little maintenance. These characteristics make them very useful in locations where inconspicuous operations are needed. 
- Reduced Reliance on Infrastructure. In the United States, the aging energy infrastructure poses a threat to national security. Electricity that is generated near the load reduces the reliance on the electricity infrastructure, thereby reducing risk.

- Diversification. Employing renewable energy reduces dependence on foreign oil, both nationally and locally, at the operational level. This helps hedge against increased oil prices and supply interruptions that could negatively affect performance at the local level. Taking advantage of renewable energy also reduces dependence on fuels supplied from regions of conflict.

- Reduced Greenhouse Gas (GHG) Emissions and Sustainable Sources. By definition renewable energy technologies are clean and sustainable. Unlike the fossil fuels that the United States relies on for most of its energy — such as coal, natural gas, and oil - renewable energy technologies are constantly replenished. Furthermore, many of these technologies are emission-free.

Considering the compelling arguments for integrating renewable energy into border security, BMD initiated efforts with NREL to examine the energy needs along U.S. borders, especially in remote areas; to identify opportunities to apply renewable energy solutions today; and to define the near- and long-term research agendas that will position border components and activities to take advantage of renewable energy technologies in the future. This report is a result of these efforts.

\section{Workshops}

The NREL staff hosted workshops for DHS BMD component staff. The purpose of these workshops was to introduce component staff to NREL and to renewable energy technologies, and to provide an overview of the BMD-NREL project. The workshops also allowed component staff to brief NREL staff on the mission and operations of the component as well as existing and future energy needs.

March 19, 2010 (Washington, DC): Introductory Workshop

This workshop was the initial meeting to convene stakeholders and outline the project and general project strategy. As a result of this workshop, CBP staff members were informed about this work effort, next steps were defined, and project points of contact (POC) were identified.

\section{June 21, 2010 (Washington, DC): Data Gathering and Application Prioritization Workshop (CBP/NREL)}

At this workshop NREL and CBP personnel presented an overview of each organization's mission and organizational structure. CBP personnel next presented an overview of the types of equipment typically used to accomplish their mission and the types of conditions under which the equipment typically is used.

There were approximately 25 pieces of equipment identified by generic name or purpose and manufacturer. Some of these pieces of equipment were grouped based on how they typically could be connected together to accomplish a specific mission. Workshop attendees then categorized the equipment into several subcategories that helped define possible power solutions for each piece of equipment. These categories were based on the following.

- Power consumption range 
- Stealth conditions under which they operate

- Length of time between refueling

- Mobility requirements

A number of considerations were made within each of these categories. One of the assumptions was that an infinite number of custom power supply sizes probably would be unrealistic as well as logistically undesirable for CBP. Workshop attendees decided to limit the number of power supply sizes to five: 1 watt (W), $100 \mathrm{~W}, 1,000 \mathrm{~W}, 7,000 \mathrm{~W}$, and 10 kilowatt $(\mathrm{kW})$. These sizes could accommodate the wattage of the current equipment being operated on the power supplies, and could be a contingency for the potential addition of equipment in the future.

Units also were initially categorized by their mobility. After the first workshop, attendees decided that mobility is not the characteristic that most strongly determines a potential solution. Visibility and the ability to refuel a unit became the more dominant characteristics in the consideration of a potential solution. Stationary units, which are not mobile, were defined by how easily they are hidden. Due to its dimensions, a large stationary communications tower would be difficult to hide visually, and therefore would not require a quiet or hidden power supply. A small communications device that could be hidden from visibility, however, could benefit from a stealthy and quiet power supply.

Because it often is difficult to find an off-the-shelf solution that has all the desired features in one unit, workshop attendees determined that the features desired in each unit should be prioritized in order of importance. CBP prioritized the following solution characteristics by desirability.

- Stealth (sound, site, dimensional limitations, refueling)

- Type of communications network utilized

- Costs (first cost, operations and maintenance [O\&M] costs, carbon costs, disposal/recycling costs)

- Reliability/robustness of the unit

- Refueling logistics (transportation of the fuel and the type of fuel)

- Time between refueling

- Replacement parts availability

- Preferred procurement methodology (three-bid or sole-source)

Additionally, to formulate an optimum solution, the following information related to the existing equipment also was requested from $\mathrm{CBP}$.

- Are there alternate manufacturers of these units and is it a custom design?

- What is the range of micro-climates, vegetation conditions, and water availability under which these units will operate?

- What is the operational energy-consumption profile of these units in terms of peak power consumption, and what is the duration of this consumption (volts (V), amps (A), watts (W), phase, alternating current/direct current $[\mathrm{AC} / \mathrm{DC}])$ ?

- Do these units need to operate off-grid?

- Do these units require emergency backup power? If so, at what level of redundancy?

- Is energy, power, or fuel storage needed? If so, why and for how long? 
- What is the length of time between refueling?

- How often does the equipment need to communicate its data back to headquarters?

- What method of communication is preferred?

Another factor that impacts the ability to bring change is the number of devices deployed for each purpose. The greater the number of devices the more incentive there is to invest in reengineering an efficient renewable energy solution.

During the workshop CBP staff listed the following tasks or issues as priorities for their organization.

- Implementing a mobile surveillance system (MSS) to replace diesel genset

- Reducing the weight and size of packable power supplies to support 5-day missions

- Reducing sound at stealth sites

- Reducing the risk of spills at all sites

- Minimizing the need to resupply at stationary/permanent sites

- Supporting recon 3, implement long-range, hand-held thermal imaging for single-person use

- Developing power solutions for tactical checkpoints and forward operating bases (FOB)

- Powering sensor packages for "low-flyer" threats

○ Low-power sensor packages, reduced-power satellite communications link

○ $20 \mathrm{~W}$ to $50 \mathrm{~W}$

NREL addressed the first seven priorities during a site visit to the southern border stations. The last item was covered during the Seattle meeting.

July 22-23, 2010 (Bellingham, WA): Northwest Border Low-Flier Workshop

During the June 21 workshop in Washington, DC, CBP requested that NREL personnel attend a meeting in Bellingham, Washington, that focused on the "low-flying" drug smugglers coming in through the northern border near Seattle, WA. The NREL staff members also were asked to present a range of possible power solutions for technologies that could detect low-flying vehicles in remote sites.

The focus of the workshop was two pronged. The first objective was to decide the technology on which to spend currently available funding so that a technology solution could be put into place immediately. The second objective was to strategize a solution for the future and develop language that could be placed in a request for proposal (RFP) to solicit sensing-technology solutions from industry professionals. There was some difficulty in developing language that was sufficiently broad enough to allow the industry maximum leeway to develop creative solutions, but at the same time to constrain solutions to functional requirements.

There was general agreement by CBP workshop participants that the short-term solution was to purchase two mobile radar units for immediate deployment. The consensus was that, although these units likely would be detected and seen by the "low-fliers," the units also would enable the channeling of the low-fliers into specific flight paths so CBP could more easily target them. 
Several months later, the scope of the RFP language was approved by the group and turned over to $\mathrm{CBP}$ procurement personnel.

\section{Site Visits}

October 26-29, 2010 (El Paso, TX): El Paso Sector

In October 2010, NREL staff visited the El Paso sector. The objective of this site visit was to gain an understanding of CBP operations along the southern border, and specifically in the El Paso sector. The visit began with an in-brief to CBP staff. The NREL staff provided an overview of NREL, renewable energy technologies, and the present project.

The NREL staff outlined site-visit expectations, which primarily encompassed gathering firsthand knowledge from users of power-consuming systems. The equipment identified as priorities in the June 21 workshop included:

- MSS

- Powering sensor packages for low-flying threats

- Reducing weight/size of packable power supplies

- Reducing sound, risk of spill, and/or resupply at stationary/permanent sites

- Recon 3

- Tactical checkpoints and FOBs.

During this site visit NREL staff worked to understand everyday operations, applications, and constraints of these technologies by speaking with operators in the field. The characteristics associated with energy-using and energy-producing equipment was collected. The staff members also worked with CBP staff to identify problems, issues, and constraints to future operations. The site visit included assessments at sector facilities, border patrol stations, border patrol permanent checkpoints, remote video surveillance system (RVSS) sites, Bridge of the Americas port of entry, border patrol special operations division, border patrol emergency planning office, border patrol tactical checkpoint, border patrol FOB, and SBInet (Secure Border Initiative) towers.

\section{April 5-9, 2011 (Juneau, Alaska): Alaska U.S. Coast Guard Operations}

In April 2011, NREL staff visited the USCG operations in Juneau, Alaska. The objective of this site visit was to gain an understanding of USCG operations in Alaska, specifically in the Juneau area. The visit began with an in-brief to USCG staff. The NREL staff members provided an overview of NREL, renewable energy technologies, and this project. They next outlined expectations for the site visit, which primarily encompassed gathering firsthand knowledge from users of power-consuming systems.

During the site visit NREL staff heard presentations from Rescue-21 (R-21) staff members and gathered extensive data regarding R-21 power needs. NREL wind turbine researchers participated remotely (via phone) and learned of the challenges of installing wind turbines on mountaintops in Alaska, and discussed potential next steps for identifying or creating a mountaintop-viable wind turbine. The NREL staff members also participated in a meeting with Alaska Marine Exchange System staff. 


\section{Renewable Energy Research and Technology Opportunities}

Renewable energy technologies can provide sustainable, reliable power for a variety of applications. Off-the-shelf technologies can be used in the near term to increase border security. Mid- and long-term research opportunities exist to develop additional technologies that better improve the operations of DHS components in supporting border security. An overview of a variety of renewable energy technologies is presented below, along with near-, mid-, and longterm research opportunities relevant to DHS security operations.

\subsection{Solar Technology Overview}

PV technologies convert sunlight directly into electricity. There are many different types and classes of PVs. Commercialized PVs are generally broken down into two categories: thin film and wafer technologies.

\section{Commercially Available Technologies} Thin-Film Photovoltaics

Thin-film PV technologies generally are deposited on a rigid or flexible substrate. They can be manufactured in continuous processes, resulting in a lower cost per unit of power produced. Because they can be deposited on flexible substrates, they also can be rolled up for easy transport. A number of different types of thin-film technologies exist, including:

- Amorphous silicon, which offers 7\% efficiency in available commercial products

- Cadmium telluride, which offers $11 \%$ efficiency in available commercial products and is the current market leader

- CIGS (copper, indium, gallium, selenide), which offers $11 \%$ efficiency in available commercial products.

\section{Wafer Photovoltaics}

Wafer PV technologies generally are made of solid silicon wafers, either mono- or polycrystalline. Silicon is cast as a single ingot and then sliced into very thin wafers; this wastes much of the material. Wafer PVs as a rule have greater efficiencies than those of thin-film technologies. Commercial products with efficiency in the range of $14 \%$ to $20 \%$ are available.

\section{Multi-Junction Photovoltaics}

Other variations of wafer and thin-films include multi-junction PV technologies. These cells layer different types of PV to capture different spectrums of light, thus increasing the overall efficiency of the composite PV system. In the past, these have been used in applications requiring the greatest efficiency for a given area or weight, such as in aerospace applications. Increasingly, these high-efficiency multi-junction devices (30\% efficiency in production) are being used in systems that concentrate sunlight by up to 500 times using either reflectors or lenses. Essentially, this allows a very small area of a more expensive and more efficient PV cell to be used with a larger area of less-expensive reflectors or lens, resulting in a system with a lesser overall cost per peak watt of power. 


\section{Reported Efficiencies of Photovoltaics}

All PV technologies can achieve higher efficiencies when produced in perfect in laboratory settings, but when these products are produced in factories these lab-based efficiencies drop. Some of this effect is due to the variability of conditions in the factory setting versus near-perfect laboratory conditions. Some is also due to manufacturers making cost-benefit decisions as to how high an efficiency to implement based on how much incremental manufacturing costs will rise to accomplish that increase in cell efficiency. This manufacturing price (in dollars per peak watt of electricity produced by the final cell) is generally what manufacturers will use to determine how high an efficiency to implement in manufacturing. Cells will compete in the marketplace on price based on the particular features and needs required by different applications. Where area and weight are important, then customers will generally be willing to pay higher prices per peak watt for higher efficiencies which will lower the area and weight.

All PV efficiencies quoted in this report are for factory-produced products.

\section{Emerging Photovoltaic Technologies}

Emerging PV technologies include dye-sensitized cells (11\% efficiency), organic cells ( $8 \%$ efficiency), and quantum-dot cells, none of which are currently produced commercially. The main difference of these products is that they can be produced without using silicon; therefore, in the future, they could be produced at lower costs.

Additionally, in the future quantum-dot technology could enable PV to be produced at higher efficiencies by targeting specific wavelengths of light.

A fourth category of emerging PV technology is based on nano-antenna (a technology-relative of the rectenna) and would consist of arrays of nano-sized antenna designed to pick up the radio frequency of the sun's rays. Only very preliminary steps have been taken to determine the feasibility of this concept.

\section{Department of Homeland Security Relevance: Photovoltaic Applications}

PV panels do not have moving parts, and when combined with batteries they are very reliableassuming there is sufficient solar resource in the area in which they are being used. Additionally, they operate silently which affords them a measure of stealth. likelihood that they would be seen is minimized.

\section{Potential Pilot Project}

The areas around the Port of Valdez in Alaska are off limits to private boaters due to the possibility of interference with oil tankers leaving the port. Twenty percent of all U.S. oil currently is shipped out of this location, making it vital to national security. At present, the only way to mark these areas is with buoys, which attract seals, which in turn attract pleasure boaters even more.

A pilot project utilizing a $\mathrm{PV} /$ battery system to provide power for a laser marking tool could be used to mark the boundary on the water surface, replacing the buoys. It also might be possible to power specialized "voice-throwing" technology speakers mounted on buoys that could notify boaters that they are in a restricted area.

Batteries currently comprise approximately $80 \%$ of the gear weight that military personnel typically carry. During site visits to the U.S. southern border, discussions with CBP field personnel revealed that batteries also comprised a significant load for these CBP covertoperations field personnel, although this can vary by mission. Border Patrol personnel who are on remote or clandestine missions could use PV chargers to provide power and thus reduce battery weight. 
Because DHS operates along the southern border, which experiences some of the country's best solar resources; this could potentially reduce the area of PV required to power and recharge the batteries used by personnel out in the field as well as for covert monitoring and sensing devices. However PV units used in Alaska would likely require some sort of additional backup power source besides PV recharged batteries during the winter months when the hours of sunlight are drastically reduced.

\section{Today's Opportunities-Off-the-Shelf Applications}

Foldable and flexible PV battery chargers can be used to recharge batteries in the field, lessening the need to carry weighty replacement batteries. Navigational buoys can use PV to charge batteries during the daytime to power lights, audible signals, or communications signals operating at night.

\section{Tomorrow's Potential}

NREL currently is working on a pilot project to integrate PV with a portable light-emitting diode (LED) light tower for use along the southern border of the United States that could dramatically reduce the need for U.S. Border Patrol personnel to refill the fuel tank on the backup diesel generator.

NREL also proposed a pilot project utilizing a PV-battery system to provide power for a laser marking tool used to show the boundary on the water surface around the Port of Valdez in Alaska. These areas are off-limits to private boaters due to the possibility of interference with tankers leaving the port. Currently, the only way to mark these areas is with buoys. Buoys attract seals which, in turn, attract pleasure boaters all the more. Because $20 \%$ of all U.S. oil currently is shipped from this location, the area is vital to national security. It also might be possible to integrate off-the shelf "voice-throwing" speakers with PV mounted on buoys that could notify boaters that they are in a restricted area. Both of these applications would save USCG personnel time and resources by allowing them to easily determine which boats present real threats versus those which are simply pleasure boats.

It could be possible to utilize high-efficiency, triple-junction PV along with specialized application-specific batteries to power small distributed-sensor units used to detect low-flying aircraft transporting drugs over the northern border. Staff members from NREL attended a workshop in the summer of 2010 aimed at planning future response to this problem. It was proposed that future units might communicate via satellite. There also are opportunities to utilize PV to power water-based sensor systems (current - possibly unknown - units, or future units used to detect vessels). It might be possible to use PV to charge micro-drones used for surveillance of fishing-vessel intruders. These hovering micro-drones could land in the water and float until they recharge. Soaring drones might stay aloft indefinitely, riding thermal currents and charging batteries during the day which then would power motors and keep them aloft at night.

Currently, CBP on the southern borders is experiencing repeated failures of standard PV panels installed at mountaintop communications sites, due to structural failure caused by high winds. NREL currently is part of the international committee to establish standards for PV based on climate-specific regions around the world. Although heat-related failures have not been reported by CBP personnel, the extreme temperatures in the southwest United States doubtlessly will require specialized PV technologies to withstand the heat exposure over time. Until an 
international standard has been established, NREL can assist DHS by writing a specification for purchasing climate-specific PV panels.

\section{Long-Term Applications and Research}

It might be possible to create camouflaged solar panels by perfecting a new class of solar panels based on nano-antenna-based solar-electric devices. This concept is in its infancy and would require additional research into nano-materials science as well as manufacturing techniques. Due to the high quantity of direct beam sunlight occurring in the areas along the southern U.S. borders, DHS may consider establishing concentrating PV arrays at sites along the border to provide power to border patrol stations, or possibly to power drones that are recharged wirelessly while hovering near the units.

\subsection{Wind}

Wind is air that has high kinetic energy, and can be transformed into useful energy via windturbine blades and generators. Uneven heating of the earth's surface creates wind energy. Warmed surfaces warm the air. The warm air rises and cooler air rushes in to take its place; the result is wind. The earth's rotation - which causes day and night—is responsible for one aspect of the heating and cooling cycle. Other factors, such as orientation or slope of a surface, or surfaces that have different rates of reflectivity, absorptivity, and transmissivity also contribute to uneven heating. Wind also can be affected (accelerated, decelerated, increased turbulence) by other factors, such as terrain, proximity of bodies of water, buildings, and vegetative cover. Overall, wind is a diffuse resource that can generate electricity cost effectively and competitively in many regions.

The economic viability of a wind project is dependent upon the interplay between the wind resource and the competing cost of electricity. A strong wind resource (Class 5 and Class 6) can compete against electricity in most areas of the continental United States. A modest wind resource (Class 2 and Class 3 ) can compete against high-priced electricity (i.e., New England, Alaska, Hawaii). Strong wind and the high cost of electricity make wind a compelling option with a short payback. Low wind and low cost of electricity might not be economically viable for wind energy.

\section{Technology Overview}

During the past decade, wind energy has been the fastest-growing energy technology in the world, with an annual growth rate in installed capacity of more than $30 \%$. The U.S. wind industry broke all previous records by installing nearly 10,000 megawatts (MW) of new generating capacity in 2009. In the first quarter of 2011, the United States had 1,100 MW of new wind capacity installed, down substantially from the pace of 2007-2009 as the effects of the recession, reduced access to capital, reduced demand for electricity, and other factors impacted wind development activities. Current U.S. wind capacity is more than 40,100 MW (AWEA 2011). In the "small wind" market — those less than $100 \mathrm{~kW}$ in size - the market grew by $15 \%$ in 2009 , resulting in $20.3 \mathrm{MW}$ of new installed capacity bringing the total installed capacity to 100 MW (AWEA 2009). 
The wind industry has several distinct sectors, each with its own technology characteristics and development/deployment strategies that apply.

- Commercial or Utility-Scale Wind: 1-MW to 3-MW wind turbines installed in groups of 30 to 600 at sites with a very good wind resource, to form wind farms that inject clean green energy onto the utility grid via transmission lines. Much of the wind industry growth is due to this sector.

- Community-Scale Wind: $20-\mathrm{kW}$ to $1,500-\mathrm{kW}$ wind turbines installed in groups of one to three on the customer side of the utility meter to reduce the amount of electricity the entity (community/school/company/etc.) purchases from the utility.

- Residential-Scale Wind: $0.1 \mathrm{~kW}$ to $20 \mathrm{~kW}$ wind turbines installed at a home or small business on the customer side of the utility meter to reduce the amount of electricity the customer purchases from the utility.

Each of these sectors of the wind industry essentially includes different technologies (they all could be called "wind turbines," but there are profound fundamental differences), assessment methods, economics, environmental considerations, and factors that serve as the drivers for those sectors.

There is a wide range of commercially available wind turbines with very different intended applications, sizes, orientations, efficiencies, and cost structures. There is no one design or size that is "the best in all applications"; rather, there are applications that favor certain sizes and designs, as they provide the better relative economics and performance within the applicationdriven constraints.

Installed cost ranges similarly are quite broad, as both the turbines and the construction factors can vary widely. Over the past 3 to 4 years, the typical installed costs of utility-scale turbines range from approximately $\$ 1,500 / \mathrm{kW}$ to $\$ 2,500 / \mathrm{kW}$. The cost of electricity generated has been in the $\$ 0.04 / \mathrm{kWh}$ to $\$ 0.08 / \mathrm{kWh}$ range over this period (Wiser and Bolinger 2009). Well-sited small wind turbines can cost in the $\$ 3,000 / \mathrm{kW}$ to $\$ 6,000 / \mathrm{kW}$ range installed, with variations due to installation and construction cost variations, availability and quality of state or utility incentives, and wind resource. The resultant cost of electricity produced could be in the $\$ 0.15 / \mathrm{kWh}$ to $0.20 / \mathrm{kWh}$ range (Windustry 2011). Poorly sited small turbines can produce electricity in the $\$ 0.20 / \mathrm{kWh}$ to $0.50 / \mathrm{kWh}$ range.

For the USCG, the need to supply reliable, less-costly power for the communications systems on remote mountaintops makes residential-scale wind turbines most applicable, although the wind turbines to consider typically would not be considered to be within the residential market. The turbines recommended for these remote locations are the most stalwart models produced by companies that specialize in robust wind turbines.

\section{Commercially Available Technologies-Current/Future Research Trends}

The primary thrust of current research efforts is toward utility-scale wind turbines focused on the following.

- Reducing installed costs of large land-based wind turbines

- Increasing turbine efficiency in wind energy conversion and electricity production 
- Reducing the cost of electricity produced by large offshore wind turbines

- Addressing renewable systems integration rules, impacts, operating strategies, and system planning to promote wind competing without disadvantage against other energy-generation technologies

- Expanding and promoting deployment of distributed wind turbines across the United States to achieve fivefold increase in unit deployment from 2007 through 2015

- Facilitating technology acceptance of utility-scale wind such that at least 30 states achieve $100 \mathrm{MW}$ of installed wind capacity with at least 15 states achieving at least 1,000 MW

In the smaller turbine market, the market drivers are:

- Improving efficiencies in blades, alternators, and inverters

- Reducing number of components and overall amount of materials to reduce installed costs

- Establishing certification facilities and protocols for small wind turbine certification;

- Improving reliability and decreasing O\&M costs

- Enabling cost-effective wind resource assessment for small turbines and projects.

\section{Wind Characteristics}

Wind resources are very site specific. Different sites in close proximity to each other, but with varying topographical features (e.g., ridges versus valleys, canyons versus mountains), vegetation (i.e., tall trees versus grassland or cropland), and surface roughness (i.e., city skyscrapers versus flat or rolling farmland), can have entirely different wind regimes. One could prove to be economic and another might not.

\section{Wind Power}

The amount of wind varies with the season, time of day, and weather events. The wind speed at any given time determines the amount of power available in the wind and subsequently the power that can be captured using a wind turbine generator. The power available in the wind is given by the following equation.

$$
\mathrm{P}=\mathrm{A} \rho \mathrm{V}^{3} / 2
$$

Where

$$
\begin{aligned}
& \mathrm{P}=\text { power of the wind (watts) } \\
& \mathrm{A}=\text { windswept area of the rotor (blades) }=\pi \\
& \mathrm{D}^{2} / 4=\pi \mathrm{r}^{2}\left[\mathrm{~m}^{2}\right]\left(\pi \mathrm{r}^{2}\left[10.76 \mathrm{ft}^{2}\right]\right) \\
& \rho=\text { density of the air }\left[\mathrm{kg} / \mathrm{m}^{3}\right]\left(2.2 \mathrm{lb} / 3.28 \mathrm{ft}^{3}\right)\left(\text { at sea level at } 15^{\circ} \mathrm{C}\right) \\
& \mathrm{V}=\text { velocity of the wind }[\mathrm{m} / \mathrm{s}](3.28 \mathrm{ft} / \mathrm{sec})
\end{aligned}
$$

\section{Multi-Agency Collaboration}

DOE created the Federal Wind Siting Information Center to provide wind developers and wind project managers with current information regarding wind turbine impacts on airport and military radar systems, NEXRAD (weather) radar systems, and military operations.

This multi-agency collaborative effort provides valuable initial siting information and feedback for all levels of wind development from community wind through large scale wind farms. (www.eere.energy.gov/windandhydro/federalwin 
Wind power $(\mathrm{P})$ is proportional to velocity cubed $\left(\mathrm{V}^{3}\right)$. Therefore, if wind velocity is doubled then wind power increases by a factor of eight $\left(2^{3}=8\right)$. Consequently, small differences (e.g., increases) in average speed cause significant differences (e.g., increases) in energy production.

To understand the wind resource at a particular site, a wind assessment typically is undertaken using a tall met tower equipped with anemometers to measure wind speed at multiple heights, wind vanes to measure wind direction, and temperature and atmospheric pressure sensors. These sensors and the data collected help to inform a number of important turbine and siting parameters. One factor of great interest to turbine manufacturers is turbulence.

\section{Turbulence}

The turbulence intensity (TI) is defined as the standard deviation of the wind speed within a time step divided by the mean wind speed over that time step; TI is a measure of wind gustiness. High turbulence can lead to increased turbine wear and potentially increased O\&M costs. At reduced wind speeds, the calculated turbulence intensity often is high but the impact of the turbulence is of little consequence to the wind turbine itself due to the low wind speeds. Turbulence at greater winds speeds is of more interest and concern to wind turbine manufacturers, as it increases wear and tear on many turbine components and can lead to premature failure.

\section{Wind Turbine Technologies}

There are a variety of commercially available wind turbine technologies for using wind energy to make electricity. Wind turbines should be designed to be robust yet efficient, and lightweight but sturdy. Turbines have rotors - also known as airfoils - that capture the kinetic energy of the wind and translate it into a rotational force that turns the rotor mechanically. The rotor is attached to a drive shaft that typically is attached to a gearbox or other electricity conversion mechanism. The design of the airfoil determines whether the rotor (and turbine) is classified as a "lift" or a "drag" wind turbine.

Air flowing over a stationary airfoil produces two forces - lift and drag. A lift force is perpendicular to the air flow and drag force is in the same direction of the air flow. A primary difference between the two as it relates to electricity production and efficiency is that the rotor of a drag wind turbine can spin no faster than the wind acting on the blade. However, a lift turbine, due to the pressure differential as the flowing air moves to an area of low pressure to get around the airfoil, can produce rotational speeds at the tip of the rotor that are much greater than the speed of the wind. The term "tip speed ratio" is defined by the angular velocity of the rotor tip compared to the velocity of the wind.

Wind turbines are designed to be well-balanced, symmetrical machines that minimize friction to maximize the mechanical energy transformed into electrical energy. Turbulent winds can cause imbalanced thrust loads into the rotor, leading to increased wear and tear on shafts, gear boxes, and bearings and resulting in premature failure. Ice loading on rotors, as expected to be experienced on mountaintop locations in Alaska, can rapidly create extreme imbalance conditions that can lead to catastrophic premature failure. Routine O\&M is a necessary aspect of the long-term viability of any turbine. Occasionally, repair and replacement of worn parts (e.g., gears, blades, shafts) are needed for a turbine to achieve its normal operating parameters. 
Utility-scale wind turbines are typically designed for particular wind conditions and turbulence factors, so a given turbine may have several models available. After an analysis of the wind resource data, if the wind conditions call for a more robust design (International Electrochemical Commission [IEC] Class I versus Class II or Class III), then that is what is specified. At sites with less wind and low turbulence, longer blades can increase wind capture. Small wind turbines have fewer, if any, optional design features.

The orientation of the shaft that transforms wind energy to mechanical to electrical energy is the defining characteristic classifying two major types of wind turbines: the vertical axis wind turbine (VAWT) and the horizontal axis wind turbine (HAWT). The HAWTs are the turbines seen most commonly in wind applications worldwide. The orientation of the shaft that transforms wind energy to mechanical to electrical energy is the defining characteristic.

Figure 2 shows various turbine configurations that have been considered for wind energy conversion machines, grouped by axis orientation.

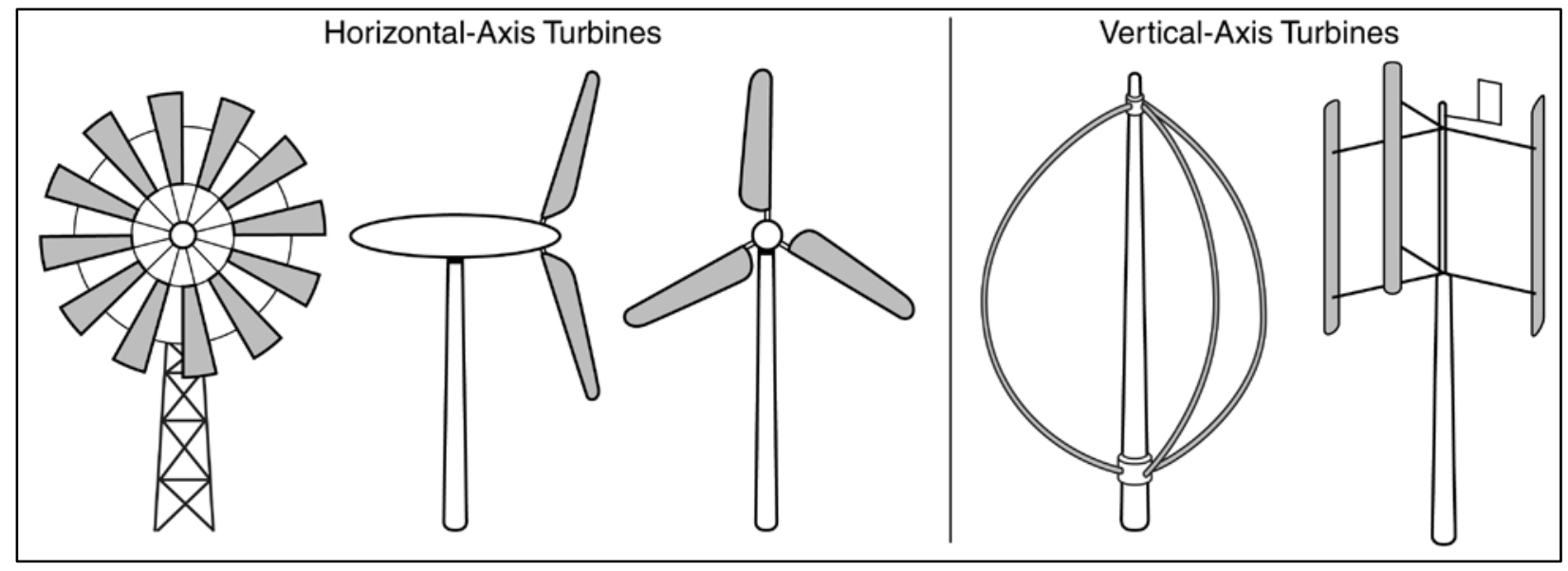

Figure 2. Various types of horizontal and vertical access wind turbines. IIlustration by Al Hicks, NREL

\section{Vertical Axis Wind Turbines}

VAWTs have been in use for many years with many different design variations. All the different designs can be categorized into two basic design types or principles: Savonius rotor and Darrieus blade, described in more detail below.

\section{Savonius Rotor}

The Savonius rotor is an impulse-type rotor, with a maximum theoretical efficiency of approximately $19 \%$; it essentially is pushed by the wind. The push principle is demonstrated in turbines originally consisting of two or more vertical sails or paddles that are blown around their vertical axis by the wind. The simplest type of wind generator is the Savonius turbine, which utilizes the push principle. In 1922, Finnish engineer S.J. Savonius substantially updated this basic concept when he replaced the sails with airfoils (essentially cups or half oil drums) with their open sides opposing each other and fixed to a central vertical shaft. The cup in line with the wind flow catches the wind and so turns the shaft $180^{\circ}$, bringing the opposing cup into the flow. 
The next cup then repeats the process, causing the shaft to rotate a further $180^{\circ}$ and complete a full rotation. There are numerous variations to this design theme, some with additional airfoils on the same shaft and some with their airfoils set at different angles or positions on the shaft.

\section{Darrieus Blade}

The other VAWT option, using the pull principle, evolved in 1931 when a French engineer, George J.M. Darrieus, invented a new type of vertical-axis wind turbine. The Darrieus-type machine consists of two or more flexible airfoil blades which are attached to both the top and bottom of a rotating vertical shaft, giving the machine the appearance of a giant egg beater. The Darrieus rotor is a thrust- or lift-type rotor, with a maximum theoretical efficiency of approximately $59 \%$; it essentially is pulled by the wind. The wind blowing over the airfoil contours of the blades create aerodynamic lift, which actually pulls the blades along. Over time, researchers have begun working to improve the Darrieus machine by rationalizing the geometry of the blades. Many different shapes and sizes have been developed.

\section{Horizontal Axis Wind Turbines}

HAWTs are most commonly seen in applications across the United States. They can range in size from as small as $400 \mathrm{~W}$ to as large as $5 \mathrm{MW}$. There are thousands of the smaller turbines used in applications to provide ranchers, farmers, homeowners, and small-business owners with the ability to generate their own electricity to partially or wholly replace electricity from the grid. Significant research and development have been undertaken in the past decade to improve the performance and reduce the cost of these smaller turbines.

The HAWTs often use a furling mechanism to orient the turbine out of the wind in extremely windy conditions and prevent turbine damage. The mechanism itself is designed for typical horizontal airflow. The mechanism can rotate the rotor out of the wind in the vertical or horizontal plane. Utility-scale turbines have controls to adjust a blade's pitch to minimize the effects of wind speeds that are too great.

\section{Upwind versus Downwind}

Wind turbines can be designed with the rotor either in front of the tower relative to the incoming wind ("upwind" turbine), or behind the tower ("downwind" turbine). There are advantages and disadvantages to each configuration. An upwind turbine requires a yaw mechanism (similar to the tail of a wind vane) that helps point the rotor in the direction of the wind. In this configuration, the rotor sees less impact of the tower on the wind although there is some interference by tower on the wind flow. The primary disadvantage of this system is that the rotor, which is attached to the nacelle, must extend far enough in front of the tower that the blades cannot bend into the tower even in extreme wind conditions. Tilt angle of the nacelle, blade flexibility versus stiffness, and the balance point of the nacelle attachment all must be integrated into the design parameters to ensure successful operation in extreme gusts or high-wind events.

The rotor also can be designed to be downwind of the tower. The nacelle itself is designed to serve as the "tail" so that the rotor will align to the wind automatically without the need for a separate yaw mechanism. The rotor blades can be more flexible, as there is much less chance of a blade hitting the tower. The more flexible blades can be a disadvantage due the potential for blade fatigue. The tower also has a greater impact on the wind flow, causing greater turbulence on the rotor and potentially greater wear and tear on blades, shafts, and gears. 


\section{Tip-Speed Ratio}

Figure 3 compares the rotor power coefficients $\left(\mathrm{C}_{\mathrm{PR}}\right)$ for different types of wind turbines with the tip speed ratio (TSR). The TSR is the ratio of the speed at the tip of the blade to the speed of the wind, and is a function of the design and type of turbine. A high TSR can generate a lot of noise and also can block the wind from moving through the rotor. A low TSR allows too much wind energy to pass through the rotor.

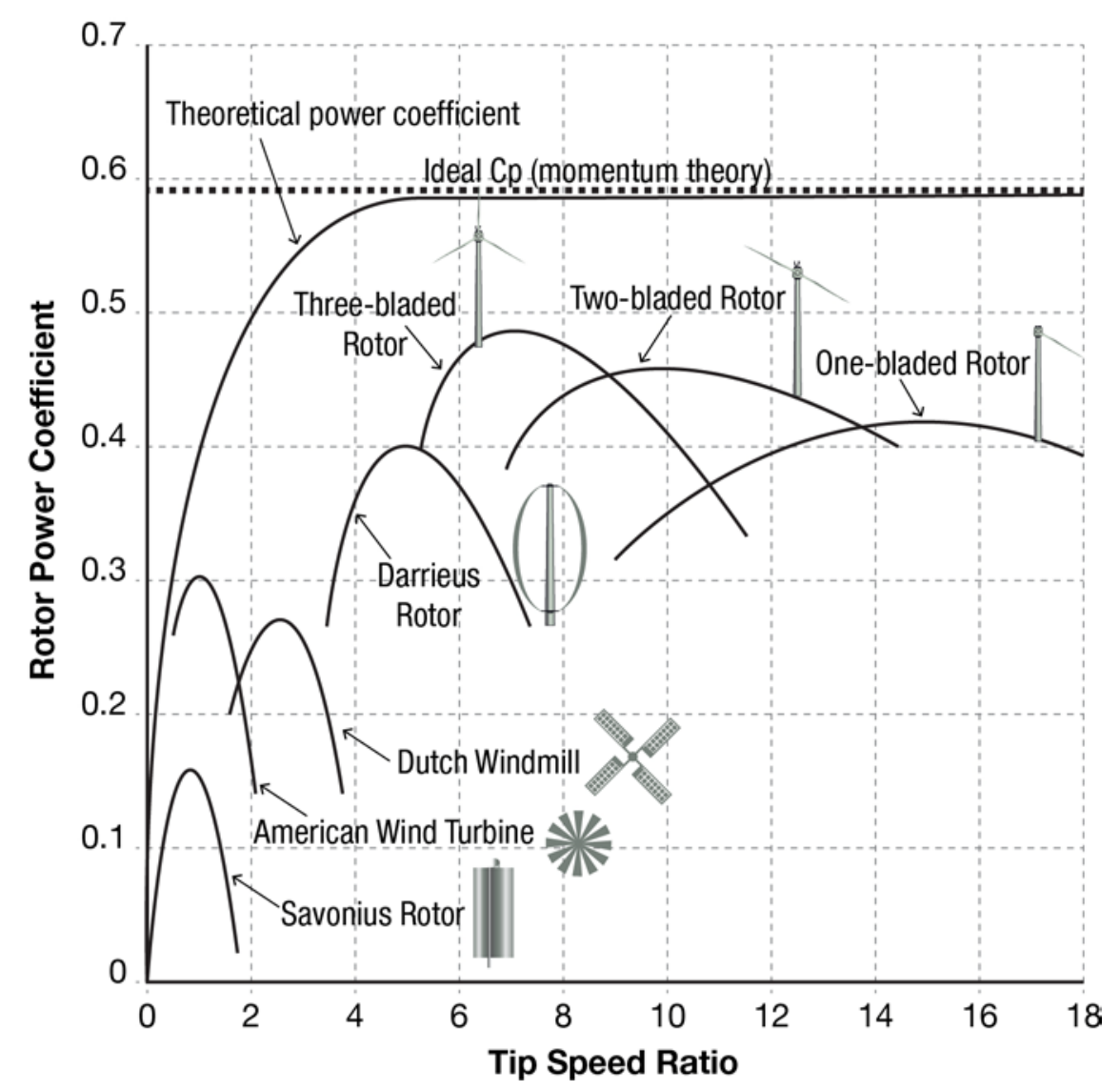

Figure 3. Comparison of aerodynamic efficiencies of common types of wind turbines (based on Hau 2000). Illustration by NREL

Typical rotor $\mathrm{C}_{\mathrm{PR}}$ values range from 0.2 to 0.45 . The lower end of the range is associated with drag-type devices such as the Savonius machines. Three-bladed HAWTs are at the highest end of the range. The wider the curve, the more efficient the design is across different wind speeds. The optimum $\mathrm{C}_{\mathrm{PR}}$ is found at TSR values ranging from 5.0 to 6.0.

One important performance consideration not easily gleaned from Figure 3 is that, although the TSR varies within a small band for each type of rotor configuration, the rotations per minute (rpm) vary widely and inversely from small to large turbines. That is, small turbines have very high rotations per minute (500 rpm to $1,500 \mathrm{rpm}$ for $1-\mathrm{W}$ to $400-\mathrm{W}$ turbines) and large turbines have very low rotations per minute (12 rpm to $28 \mathrm{rpm}$ for 1-MW to $3-\mathrm{MW}$ wind turbines). 


\section{Department of Homeland Security Relevance: Options for Powering Remote Communication Stations}

The "Wind Power Rescue 21 Alaska" report, ${ }^{1}$ completed by the USCG and provided to NREL, was very useful in understanding the realm of the challenging environment the mountaintop communications system operate in, particularly during the fall-winter-spring months. The "Alaska NDS Support" systems are designed to operate from one of two battery banks (combined 2,000 A/hr capacity). Power generation is supplied to the battery banks with either a propane generator (redundant $7.5-\mathrm{kW}$ generators) or using PV modules (2.88 $\mathrm{kW}$ peak power). A PV system provides charge to the batteries, if needed, whenever the sun is shining. Most of this charging is expected to be in either the float- or trickle-charge phase of battery charging, when the battery bank is partially discharged. The propane generator provides bulk charging whenever the battery system voltage falls below a preset state of charge. This cycling approach is intended to minimize the runtime of the generator, as it only turns on when bulk charging is needed.

A wind system would operate in a manner similar to PV by serving to provide float charge or trickle charge to the batteries whenever the wind is blowing. It is conceivable that during periods of high wind and low battery state of charge a wind system even could provide bulk charging, although it might be better to keep the operational algorithms simple and consistent.

If a wind turbine is added to the existing system it is conceivable that it would be necessary to add a load bank into the hybrid system configuration to provide load, particularly when the wind system is producing at half or more of its rated power and the battery system is in float- or trickle-charge phase.

\section{Today's Opportunities: Best Current Wind Options for the Department of Homeland Security}

The "Wind Power Rescue 21 Alaska" report provided useful information regarding rapid catastrophic failure of two "robust" HAWT turbines.

- HR3 $(3 \mathrm{~kW})$ by Northern Power Systems; no longer in production

- Bergey BWC $1500(1.5 \mathrm{~kW})$ by Bergey WindPower; no longer in production although the nominal equivalent is the XL.1 $(1.0 \mathrm{~kW})$ turbine

The HR3 turbine has been known to perform consistently in the harsh environment and extreme winds on Black Island in Antarctica at a National Science Foundation communication station. Five of six deployed HR3's in Alaska, however, did not survive the first winter. There is not enough information available to have confidence in speculating on the reasons for this vast difference in performance. The sole "survivor" was on Naked Island, which has milder weather than the other locations. More details on the precise failure modes would be insightful, although it is understood that the failure mode might not have been obtainable due to the remoteness of the sites, the extreme conditions that cause failure, or the time lapse between failure and the arrival of project personnel.

According to the "Wind Power Rescue 21 Alaska" report, twelve Bergey BWC-1500 (1.5 kW) wind generators were installed at six sites in southeast Alaska, but all failed. Initially the BWC1500 failures were suspected to be caused by a blade flexing and striking the tower, therefore

\footnotetext{
${ }^{1}$ Provided to NREL's A. Kandt and S. Huffman by DHS.
} 
several failed units were replaced with stiffer blades and a smaller tower-mount pipe. None of the BWC-1500 wind generators survived a full year even with these changes.

As stated in the report, there is no "true" or verified cause of the failure of these wind turbines. It is speculated that the failure could have been due to a combination of ice loading and turbulent wind. Ice loading can cause static loads in excess of design parameters, and rotational loads that are imbalanced and exceed design loads. These appear to be among the potential causes for premature failure. There also could be other root or contributing causes.

There is no easy, fail-safe, off-the-shelf wind energy solution for this application, given the costs of providing propane annually per site (approximately $\$ 25,000 / \mathrm{yr}$ to $\$ 26,000 / \mathrm{yr}$ ) and in aggregate (approximately $\$ 400,000 / \mathrm{yr}$ to $\$ 420,000 / \mathrm{yr}$ ), as well as the great risks associated with airlifting fuel to the high sites. However, there could be several options worth pursuing on a pilot project or field-test basis. The goal of the field test would be to determine wind turbine viability and expected life in these environments, thus enabling the determination of an approximate overall life cycle cost (LCC) for the system as compared to business as usual (BAU).

The goal of the field test and subsequent analysis would be to achieve a reasonable cost savings over the life cycle of a wind turbine (and the entire hybrid power system). A conceivable scenario (not usually considered "successful") could include wind turbine failure within 5 years (this is an arbitrary number), rather than its design life of 20 years, if there were substantive savings accrued over those 5 years as compared to business as usual. If, over a 5-year period, fewer helicopter trips are needed per year or generator run-time is reduced enough that overhaul or replacement is delayed by 1 to 3 years, for example, then a 5-year wind turbine life might be more economically advantageous than business as usual. The overall net result would be an improved, but not perfect, system.

\section{Pilot Opportunities for Wind Turbines}

From discussions with various turbine manufacturers and direct experience with a variety of wind turbines in extreme environments, two types of rugged wind turbines designed for extreme conditions appear to merit the field test: a VAWT with narrow Savonius rotor, and a HAWT with spring-loaded furling blades.

\section{Savonius Option}

A variation of the Savonius turbine can be seen in the Windside ${ }^{2}$ turbine design, in which the drums of the Savonius rotor have evolved into fluted, spiral-formed vanes. The Finnish company, Oy Windside Production, produces this machine. It consists of two vertical curved airfoils mounted between two disks. Whenever wind blows horizontally through this device, the disk turns and drives a generator. These machines are suited for use on buoys, offshore platforms, buildings, signs, and posts, which require only small amounts of power. They often also are used to charge battery backup systems or to supplement low-voltage PV solar panels, and to power signs, public telephones, low-voltage transmitters, and other small systems. They are well-suited for isolated areas with severe weather. The turbines are simple, rugged, and reliable, and come in sizes with output of up to $3 \mathrm{~kW}$.

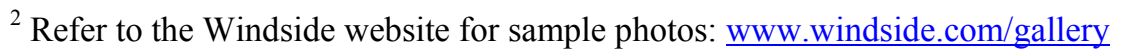


Other benefits include the following.

- Turbine can accept wind from any horizontal direction (omnidirectional) so is does not use slip rings or a yaw mechanism

- Very rugged design suitable for harsh climates

- Generator is on the ground, so it is easier to service than most HAWTs

- Direct-drive permanent-magnet generator with no gearbox

- Slower rotor movement can make the turbine more visually pleasing than that with a rapidly spinning blade

- Wind tolerance limits are $60 \mathrm{~m} / \mathrm{s}(134 \mathrm{mph})$

- Multiple size options

Disadvantages of the Savonius turbine include the following.

- Very low efficiency

- Cannot reduce wind profile in extreme wind events

- High weight-to-energy production ratio - the added cost of transportation and a foundation should be considered as part of the cost of energy — not recommended for building-top applications

- High cost-to-energy production ratio

- The $50-\mathrm{Hz}$ model could be the only frequency option (this might not be an issue for batterycharging-only system)

This turbine is designed for extreme weather conditions - such as the arctic and the desertwhere a small amount of power is needed and other alternatives do not work well. Consequently, its high cost of energy is not a limiting factor for these applications.

\section{HAWT Option}

Proven Energy manufactures a series of downwind wind turbines designed for a range of extreme conditions. ${ }^{3}$ One unique design feature of the downwind turbine is its spring-loaded blade furling design. In strong winds, the hinges allow the blades to hinge back out of the wind, dissipating wind energy by reducing the effective size of the swept-area plane perpendicular to the wind and helping to control rotor speed.

Proven Energy products include a patented blade assembly, which allows the wind turbines to regulate speed, thus maximizing output. As the wind gets stronger, the blades pitch and cone to reduce their aerodynamic efficiency. This lets the Proven Energy wind turbine maintain a high output even in the fiercest storms - unlike many turbines which require braking to protect themselves at high wind speeds.

The Proven $11(5.2-\mathrm{kW})$ or $35-2(12.1 \mathrm{~kW})$ turbines might be appropriate sizes to consider. Benefits of this technology include the following.

- Hinged blade-furling system reduces turbine overspeed events

- Direct-drive permanent-magnet generator does not require a gearbox

\footnotetext{
${ }^{3}$ Visit Proven Energy at www.provenenergy.co.uk/our-products/ or Alaskan Wind Industries at www.akwindindustries.com/allproven.php for more information.
} 
- Very rugged design suitable for high-wind or gusty regimes

- Wind survivability limits are $70 \mathrm{~m} / \mathrm{s}(134 \mathrm{mph})$ for the Proven 11 , and $54 \mathrm{~m} / \mathrm{s}(121 \mathrm{mph})$ for the Proven 35-2

- Multiple size options

Disadvantages of the HAWT turbine include the following.

- High cost-to-energy ratio

- Blade length can lend itself to rotor imbalance during icing events

- Must yaw into the wind - in swirling winds this can lead to excessive wear chasing the wind The Proven 11 turbine shown in Figure 4 is designed for extreme weather conditions in remote places.

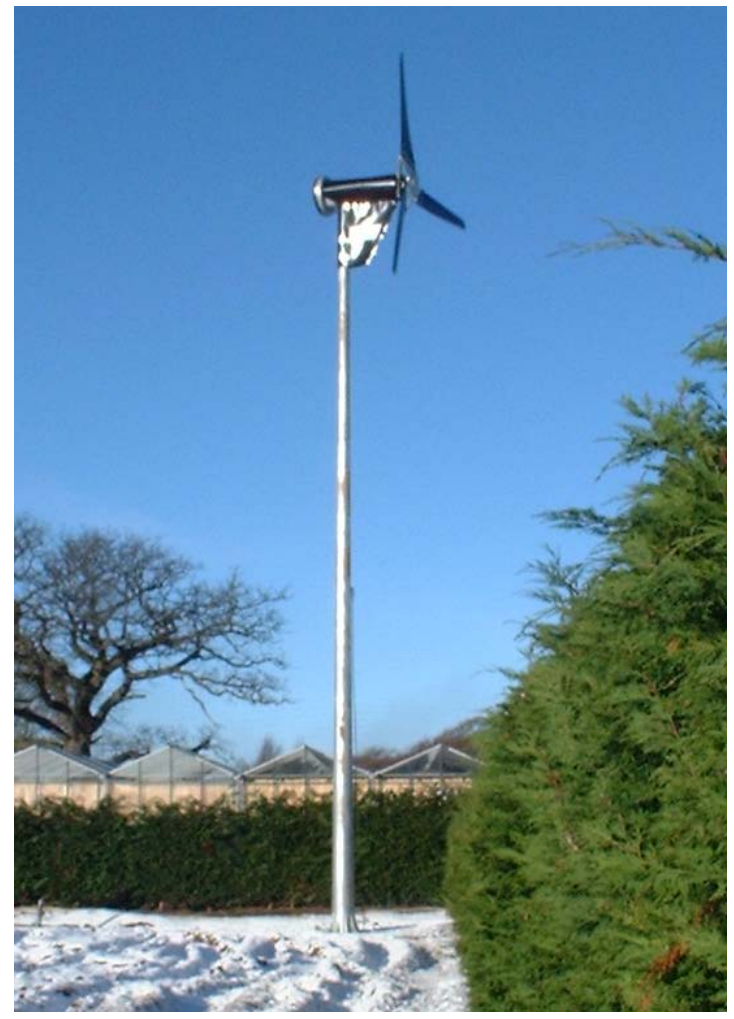

Figure 4. Proven 11 downwind turbine with spring-loaded blade furling design. Photo from Proven Energy

\section{Tomorrow's Potential: Wind Turbine Field Test Plan Outline}

It is worthwhile to proceed with a multiyear field test aimed at building on incremental success and learning from potential failures, versus expecting the perfect solution to emerge from the first test. Over time, improved system designs, equipment selection, and siting guidelines are expected to emerge and to result in better-performing systems at a lower cost than existing systems. Although the selected turbines might fail to survive in the short term, both provide promising opportunities to develop more-robust turbines for comparable applications worldwide. 
NREL recommendations to DHS include the following.

- Have DHS field service personnel inquire with multiple manufacturers about taking a wind installation and O\&M workshop

- Select midrange sites in terms of extreme weather for each turbine

- Have DHS field personnel take wind turbine siting training

- Purchase, install, and field test two of the most ruggedized manufacturers' turbines at the same time and location in Year 1
Potential Research Project

Both of the selected manufacturers have been working to improve wind-turbine design and performance over time. Being able to provide them with test sites that are able to support additional data collection might be of interest to these companies.

Although these turbines represent a narrow segment of small markets with limited applicability, they also represent very highvalue projects with a significant need for improved performance.

- Collect as much useful practical data from each installation each year (i.e., wind-speed data from multiple heights on a tower, wind vanes at multiple heights) for analysis

- Analyze the collected data at each site and complete a "Lessons Learned" report

- Develop improved turbine selection, siting, and configuration guidelines based on "Lessons Learned" report

- Repeat this process through several iterations over a 4- to 6-year period, to evolve better wind turbine options and solutions for remote DHS communication sites in Alaska.

\section{Long-Term Applications and Research}

DHS and NREL could work with wind turbine manufacturers on several design-parameter improvements targeting the weather extremes of mountaintops and Alaska in particular. No contact yet has been established with these manufacturers, but NREL is interested in leading this discussion should DHS likewise be interested in this pursuit. Potential areas of design alteration might include the following.

- Windside - Enlarge shaft or bearings to enhance durability

- Proven-Reduce blade length to reduce impact of rapid gusts

The manufacturers could have their own ideas of the design parameters they are interested in refining or altering for these types of extreme sites.

Also, a defrosting unit could be developed to utilize the heat from backup power generators to de-ice ruggedized horizontal wind turbines used to power communications equipment on mountaintop sites. This technology would ensure that fossil fuels generally only would be used when a wind turbine has been stopped due to ice buildup. This also is precisely the conditions under which waste heat would be available to defrost the turbine blades, thus minimizing the need to use and transport backup fuel to these dangerous sites.

\subsection{Energy Transfer Overview}

Energy transfer technologies are an important component of energy-using systems. They enable the transfer of energy from a power producing source, such as PV panels or a wind turbine, and they transfer it to the energy consuming device, such as a communications or light tower system. 


\subsubsection{Batteries}

Based on the CBP and USCG applications identified during NREL site visits, there is need for batteries with the following characteristics.

- Improved energy density for portable power applications associated with hand-held devices and remote field operations.

- Improved cycle life for integration with renewable energy storage involving communications, sensors, lighting, tracking, and boundary markers. In some cases, the main emphasis is to increase the times between change-outs and maintenance to decrease life-cycle costs and any hazards to people.

- A broader operational temperature range for use in extreme conditions such as cold mountaintops or hot deserts.

Specific needs and research and development (R\&D) gaps will depend explicitly on the performance requirements of each electronic system. This data has not yet been procured from DHS, but these three areas outline the general development needed for batteries.

\section{Batteries Technology Overview-Current Status}

United States energy security and viable, large-scale, renewable-energy options to a great extent depend on revolutionary developments in battery and fuel-cell technology for transportation, portable power, and stationary energy-storage applications. Batteries and fuel cells are being developed because they offer the potential for greater efficiency energy utilization and perhaps energy storage. Existing batteries and fuel cells currently have substantial cost, durability, temperature, and energy-storage density problems.

In general, due to their relatively low costs, deep-cycle lead acid batteries are widely deployed and are the most common renewable-energy storage system in use. Depending upon the specific application, however, commercially available lithium-ion (Li-ion) and other batteries might compete very well on a full life-cycle cost basis and could provide superior performance. As shown in Table 1, present secondary (rechargeable) batteries typically are limited to gravimetric energy densities below $200 \mathrm{Wh} / \mathrm{kg}$ and have cycle lives of fewer than 500 cycles. Metal hydride batteries typically have lower energy densities than $\mathrm{Li}$-ion-based batteries because the metals are substantially heavier, even though hydrogen (the lightest element) is used as the principal energy carrier. Even other metal-air batteries, such as zinc-air, have relatively low energy densities because the elements are heavier (i.e., the molecular weight of zinc is $65.39 \mathrm{~g} / \mathrm{mol}$ ). Again, depending on the specific application, greater cycle lives can be achieved with commercially available lithium iron phosphate (LiFePO4)-based batteries, which also offer very good discharge and recharge rates. 
Table 1. Comparison of Typical Energy-Storage and Delivery Systems

\begin{tabular}{|c|c|c|c|c|c|c|c|}
\hline \multirow[b]{2}{*}{ System } & \multirow[b]{2}{*}{ Anode } & \multirow[b]{2}{*}{ Cathode } & \multirow{2}{*}{$\begin{array}{l}\text { Voltage } \\
\text { (nominal) } \\
V\end{array}$} & \multicolumn{2}{|c|}{ Energy Density } & \multirow{2}{*}{$\frac{\text { Cycle Life }}{\text { Cycles }}$} & \multirow{2}{*}{$\frac{\text { Cost }}{\$}$} \\
\hline & & & & Wh/kg & Wh/l & & \\
\hline $\begin{array}{l}60 \% \text { Efficient Fuel Cell } \\
\text { with Tank }\end{array}$ & $\mathrm{Pt}$ & $\mathrm{Pt}$ & 1.3 & $<600$ & $<500$ & $\sim 4000$ (hours) & $\$ \$ \$$ \\
\hline Supercapacitors & $\mathrm{NA}$ & NA & NA & 10 & NA & $>10^{6}$ & $\$ \$ \$$ \\
\hline $\begin{array}{l}\text { Gas with } \sim 35 \% \text { Efficient } \\
\text { Engine }\end{array}$ & NA & NA & NA & $<500^{1}$ & $<400^{1}$ & $\sim 2,000$ hours & $\$$ \\
\hline Lithium-Air (Li-air) & $\mathrm{Li}$ & $\mathrm{O}_{2}$ (air) & $\sim 3$ & $\sim 360^{2}$ & $\sim 400$ & $\sim 60$ & $\$ \$$ \\
\hline Lithium-Sulfur & $\mathrm{Li}$ & $\mathrm{S}$ & 2.2 & $\sim 1000^{2}$ & $\sim 1100$ & $\sim 50$ & $\$ \$$ \\
\hline Planar Lithium & $\mathrm{Li}$ & Oxides & $\sim 4$ & $\sim 400$ & $\sim 600$ & $>1000$ & $\$ \$ \$$ \\
\hline $\begin{array}{l}\text { Thin-Film Li/Lithium } \\
\text { Phosphorous Oxynitride } \\
\text { (LiPON) Electrolyte }\end{array}$ & $\mathrm{Li}$ & $\mathrm{LiCoO}_{2}$ & 4.2 & $200^{*}$ & 450 & 100,000 & $\$ \$ \$ \$$ \\
\hline LiFePO4 & $\mathrm{C}$ & LiFePO4 & 3 & 90 & 183 & $\begin{array}{l}>2000 \\
(@ 80 \%)\end{array}$ & $\$ \$$ \\
\hline Lead-Acid & $\mathrm{Pb}$ & $\mathrm{PbO}_{2}$ & 2 & 35 & 70 & $200-250$ & $\$$ \\
\hline Nickel-Cadmium & $\mathrm{Cd}$ & Ni oxide & 1.2 & 35 & 80 & $400-500$ & $\$ \$$ \\
\hline Nickel-M-Hydride & $(\mathrm{MH})$ & Ni oxide & 1.2 & 50 & 175 & $400-500$ & $\$ \$$ \\
\hline Lithium Ion & $\mathrm{C}$ & $\mathrm{Li}_{\mathrm{x}} \mathrm{CoO}_{2}$ & 4 & 170 & 300 & $>500$ & $\$ \$ \$$ \\
\hline Lithium-Organic & $\mathrm{Li}$ & $\mathrm{MnO}_{2}$ & 3 & 120 & 265 & 500 & $\$ \$ \$$ \\
\hline Edison & $\mathrm{Fe}$ & Ni Oxide & 1.2 & 30 & 55 & & $\$$ \\
\hline Silver-Zinc & $\mathrm{Zn}$ & $\mathrm{AgO}$ & 1.5 & 90 & 180 & & $\$ \$$ \\
\hline Nickel-Zinc & $\mathrm{Zn}$ & Ni oxide & 1.6 & 60 & 120 & & $\$$ \\
\hline Nickel-Hydrogen & $\mathrm{H}_{2}$ & Ni oxide & 1.2 & 55 & 60 & & $\$$ \\
\hline Silver-Cadmium & $\mathrm{Cd}$ & $\mathrm{AgO}$ & 1.1 & 55 & 100 & & $\$ \$ \$$ \\
\hline Zinc-Air & $\mathrm{Zn}$ & $\mathrm{O}_{2}$ (air) & 1.5 & 150 & 160 & & $\$$ \\
\hline \multicolumn{8}{|c|}{$\begin{array}{l}\text { Note: Technologies shaded in light blue are in development or are not commercially available and are compiled from many } \\
\text { different sources. The remainder can be found in the Handbook of Batteries, Third Edition (Linden and Reddy 2002). } \\
\text { * Depends upon substrate type and thickness. } \\
\text { 1. Note energy densities are reduced because tank and engine weights are included. } \\
\text { 2. Best demonstrated; Li-Air and Li-S batteries have the potential to be greater than } 2,500 \mathrm{Wh} / \mathrm{kg}\end{array}$} \\
\hline
\end{tabular}

DOE and the U.S. Advanced Battery Consortium (USABC) have been developing Li-ion batteries for hybrid and plug-in hybrid electric vehicles with the near-term goals of $140 \mathrm{Wh} / \mathrm{kg}$ and $\$ 20 / \mathrm{kW}(\$ 250 / \mathrm{kWh})$ at large-scale production. There are significant doubts in the battery community as to whether the energy density of li-ion batteries will be able to be pushed to the $200+$ watt-hour per kilogram (Wh/kg) system (300 watt-hour per liter [Wh/L]) level energy densities and the more than 1,000 cycle lives required for widespread deployment of all-electric vehicles. Development efforts to try and meet these goals, however, are focusing on improved materials, architectures, and manufacturing processes.

\section{Developmental Batteries Overview}

Lithium-air batteries offer relatively high energy densities, but the required transport and permeation of oxygen often limits rates to charge and to discharge, and have substantial overpotentials that reduce recharge efficiencies. Overpotential is the added electrical or ionic resistance in the battery due to different competing mechanisms. Substantial development is needed to improve membranes and electrolytes to create highly durable secondary Li-air batteries with long lives. Similarly, lithium-sulfur (Li-S) batteries that use very inexpensive 
earth-abundant materials have the potential for high energy densities but have relatively poor cycle life and require substantial development.

In general, typical commercially available Li-ion and other batteries last a few hundred cycles when discharged to $\sim 80 \%$ of their full capacity. This means that, to maximize cycle life, additional capacity must be included, ultimately increasing weight and costs. Furthermore, for renewable-energy storage applications that typically cycle daily, most batteries will require replacement within a year or two unless additional capacity is added to decrease the depth of discharge. Basically, by decreasing the depth of discharge to approximately $50 \%$, more than 1,000 cycles can be achieved and, in some cases, 5 to 10 years between replacements can be designed for a specific power system.

A few high-cycle life batteries are being developed, but capacities and rates are major issues. In addition to cycle life and energy density, battery performance typically decreases substantially at colder temperatures, also requiring extra capacity to be included to provide the required power and energy storage. In general, a few rechargeable batteries can operate to approximately $-20^{\circ} \mathrm{C}$; thus, battery heating systems must be included for operation where temperatures are lower. This requires increased capacity to adequately address the heating system's power requirements.

Depending upon pulsed power, change-out time, and system-life requirements, a complete energy-storage system could require primary and secondary batteries with supercapacitors, and potentially even reversible fuel cells. These types of evaluations are performed routinely, but are very dependent upon the application and the operating conditions.

\section{Department of Homeland Security Relevance: Battery Development}

Depending on the specific application, DHS will require different levels of battery research, development, and integration to provide cost-effective and enabling solutions. Technology foraging will enable DHS able to leverage past and present work performed by industry, NASA, the U.S. Department of Defense (DOD), In-Q-Tel, and DOE to provide energy-storage systems optimized for specific DHS missions. For example, DHS requirements for batteries with higher energy densities, greater power, faster rates, longer cycle life, and wider operational temperature range are very similar to requirements by industry, DOE, NASA, DOD, and other agencies that need transportation, portable, and stationary energy storage.

\section{Today's Opportunities-Near-Term Integration with Commercially Available Batteries} Battery technology is advancing and new performance capabilities are becoming available, therefore it is prudent to reevaluate energy storage solutions for several DHS missions. DHS can consult with national laboratories, DOD, NASA, and industry to identify potential advanced energy-storage solutions for present DHS missions. DHS could then work with In-Q-Tel or similar entities to bring these innovations into fruition. These evaluations can include appropriate batteries, supercapacitors, and other integrated components, as well as any system testing necessary to demonstrate safe operation that meets the performance requirements.

\section{Life-Cycle Cost and Durability Evaluations}

Many handheld and remote field-operation devices can use a wide range of relatively new dropin batteries and supercapacitors that can increase operating times, decrease weight, and decrease overall life-cycle costs. Rechargeable Li-ion batteries, for example, are available commercially 
in a vast array of energy-storage packages that can directly replace battery packs in existing electronic devices.

The primary effort requires identifying appropriate replacement batteries and performing a quick life-cycle cost analysis to determine the cost savings. Additionally, some effort could be required to ensure that the replacement batteries are safe and meet performance requirements. This can be accomplished by working with manufacturers and other agencies, and performing durability and failure testing.

\section{Replacement-Battery Evaluations}

Similarly, DHS can work with manufacturers, national laboratories, other agencies to identify and design near-drop-in ready energy-storage solutions for renewable energy storage applications where longer cycle lives are needed to increase the times between change-out and maintenance. In the near-term this can be done by identifying commercially available advancedbattery solutions and designing the appropriate depth of discharge needed to meet the cycle-life performance requirements.

These evaluations require a tradeoff of lesser overall battery costs for increased performance requirements. For example, Li-ion batteries probably can be used for remote, cold, mountaintop communication and tracking applications. The greater costs of the Li-ion batteries, however, will be increased further by the need for enhanced capacity. The greater capacity is needed to adjust depth of discharge for the desired change-out times, the cold temperatures, and the additional heating required to keep the battery temperatures above $-20^{\circ} \mathrm{C}$. These design issues will be balanced against the elimination of maintenance costs and the reduced costs of transporting and changing-out batteries, especially where physical safety is a major problem.

Similar battery evaluations and initial testing can be performed for any of the other DHS applications associated with lighting, tracking, sensors, and boundary markers. As compared to lead-acid batteries, Li-ion batteries require three times less weight and volume to provide the same power and energy storage. This leaves substantial weight and area for developing a drop-in replacement that has the extra capacity - and temperature-control capabilities - needed to meet mission goals, including more than doubling the time between change-outs and maintenance.

Another potential application for DHS would be to optimally combine primary batteries with supercapacitors or advanced secondary batteries (depending on the mission specifications) for remote sensing and monitoring equipment. For equipment such as seismic monitors that only sends out signals when specific events activate the system, perhaps a long-life primary battery such as Li-thionyl chloride battery — which has energy densities of approximately $750 \mathrm{Wh} / \mathrm{kg}$ can be integrated with rechargeable batteries and supercapacitors for communications equipment. In this case, the primary battery provides a low level of power for the sensor to continually perform its monitoring function, and then charges a secondary battery or supercapacitor for the much greater power required to send communications.

Li-thionyl chloride batteries are relatively inexpensive and have very low self-discharge, which enables 10 to 20 years of continuous operation (as compared to the approximately 1-year operation of many rechargeable batteries). This makes these batteries ideal for some 
applications - such as the remote detection of seismic events caused by people walking, for which hundreds of thousands of sensors are needed and cost will be a primary driving factor.

\section{Tomorrow's Potential—Battery Development and Prototype Demonstration}

Addressing some DHS mission specifications will require development and demonstration efforts during the next 3 to 5 years. Although this is not sufficient time to perform the research required to develop batteries with fundamentally new performance capabilities, it is sufficient to redesign and reconfigure energy-storage systems for specific applications and to perform longerterm demonstrations and testing. The greater power demands of remote lighting, tracking, and boundary markers, for example, requires substantial amounts of design, integration, and testing work. Most of these applications presently rely on grid electricity or diesel generators.

In general, the integration of battery energy storage with renewable-energy generation from wind and PV installations is a commercially available set of technologies. The integration of largecapacity batteries for some of these applications with renewable energy generation and perhaps fuel cells, however, requires significant design and prototype demonstration efforts. Sandia National Laboratory, for example, is developing prototype portable-lighting demonstration systems using hydrogen fuel cells. Additionally, NREL is developing technology to optimize the conversion of wind electricity to hydrogen generation. In both cases, the significant high power demands have required several years for the engineering and testing to demonstrate high-quality performance. Similar efforts are required to adequately resolve battery-based or batteryintegrated renewable energy storage for high-power applications such as remote or portable lighting, tracking systems, communications, and boundary markers.

\section{Mountaintop Communications and Tracking Systems}

As discussed, existing Li-ion batteries with heaters and limited depth of discharge can be designed and evaluated in a relatively short time to determine whether they are full life cycle cost-effective replacements for these applications. If appropriate solutions are identified, then a longer-term prototype engineering demonstration effort is required to optimize performance and demonstrate that the performance criteria can be met. This will include scaled or full-scale testing under appropriate cold-temperature conditions to show that the battery systems can meet the mission goals.

\section{Remote Seismic Sensors}

The redesign of the energy-storage system for seismic sensors also can be performed relatively quickly to determine the appropriate commercially available solutions. Given the harsh conditions and long on-station lifetime requirements of these systems, however, appropriate accelerated durability and performance tests will be needed to ensure that the performance goals are fully met. Additional prototype field-testing and long term health monitoring also is required to help identify areas that need to be improved.

\section{Remote/Portable Lighting}

Due to the very high power and high renewable energy storage requirements of lighting applications, substantial design and evaluations with scaled (and then full-scale) prototypes is needed to demonstrate that such large systems can be integrated in relatively small spaces and can meet the performance objectives in harsh environments. This especially is an issue if Li-ion 
batteries are used in applications in which thermal runaway is a major concern that requires engineered solutions to ensure safe operation.

\section{Boundary Markers}

Similar to the lighting application, most boundary marker renewable energy storage systems will require high power and high capacities. In the case of the USCG Seward Harbor Laser and warning annunciator boundary markers, however, the power requirements probably are well beyond what batteries alone can provide cost effectively. In this case, batteries, fuel cells, and hydrogen generation and storage, all must be optimally integrated directly with wind, PV, tidal, and wave renewable-energy generation.

DHS, with NREL's support, could work with the Naval Research Laboratory to integrate commercially produced fuel cells from Ford or General Motors with novel underwater hydrogenstorage expandable tanks to provide the primary power for the boundary markers when renewable energy is not available. This effort would leverage NREL's work on optimized wind to hydrogen. Additionally, integrating secondary batteries and supercapacitors could meet the peak- and rapid-power requirements of the application, such as when the fuel cell is starting up and for providing continuous high-quality power from fluctuating renewable energy sources.

\section{Solid-State Secondary Lithium-Battery Development}

NREL is actively working with Planar Technologies to develop a solid-state Li-battery that has up to $400 \mathrm{Wh} / \mathrm{kg}$ energy densities and well beyond a 1,000-cycle life. Unlike present solid-state batteries, Planar is integrating cathodes with high capacities and working with DOE's Advanced Research Projects Agency-Energy (ARPA-E) and DOD to optimize these batteries for the high power requirements of transportation applications.

Based on present development efforts, NREL can work with Planar, DOE, and DOD to develop integration strategies for these new batteries with applications that could be suitable for DHS. These batteries potentially will have approximately four times the energy density and two to ten times the cycle life of commercially available Li-ion batteries, therefore many DHS applications could be directly improved with the Planar battery. Additionally, although specific coldtemperature performance has not been measured, the solid-state nature of the battery should be more appropriate with cold temperatures — even well below $-20^{\circ} \mathrm{C}$ - thus affecting cold mountaintop communications and tracking applications as well. As this technology is developed and moved to commercial manufacturing, NREL will continue to work with all participants to identify DHS applications where the Planar battery is an effective replacement based on full lifecycle costs.

\section{Durability and Performance Testing of Batteries for Specific Missions}

With all these mission-specific efforts, DOE can leverage its battery-testing expertise and work with other agencies and with industry to provide appropriate durability and safety testing of the prototype energy-storage systems developed. This would involve determination of failure mechanisms and catastrophic failure analyses. Additionally, long-term cycle testing and accelerated testing (where possible) can be performed to fully demonstrate that mission objectives can be met. Lastly, DOE can monitor installed systems in the field to provide realworld performance tracking that can be used to improve the systems. 


\section{Long-Term Battery Research and Development Advanced High Energy-Density and Cycle-Life Batteries}

In general, low-cost batteries with higher energy densities, high cycle lives, and a wider range of operating temperature are needed to meet or enhance many DHS missions. As noted, Li-air and $\mathrm{Li}-\mathrm{S}$ batteries offer tremendous potential to meet these requirements, but require focused $\mathrm{R} \& \mathrm{D}$ to overcome fundamental challenges. Both Li-air and Li-S use earth-abundant, inexpensive materials that have very high theoretical energy densities - well in excess of even presently available fuel cells when the hydrogen storage system is included.

DHS can work with other agencies and institutions to leverage existing development efforts at NREL that can provide improved sulfur stabilization with conducting nanomaterials and improved architectures, designs, and materials for oxygen integration with lithium. As is the case for hydrogen-air technology associated with fuel cells, lithium-air technology has the potential for very high energy densities because the inherent weight of the cathode material (i.e., oxygen in the air) is not carried with the battery. However, some weight associated with oxygen dissociation and separation decreases overall Li-air battery energy densities.

Similarly, the sulfur in an Li-S battery is very light and the extra weight of the sulfur cathode is somewhat offset by the higher voltages attained with the sulfur as compared with the Li-air system. Lastly, the ultimate element for batteries is the lightest (i.e., hydrogen). NREL is developing hydrogen-based batteries with potential energy densities in excess of 3,000 Wh/ $\mathrm{kg}$. It also is developing organic radical batteries with more than $1,000 \mathrm{Wh} / \mathrm{kg}$. The key here is the use of lightweight materials to store the hydrogen. In all these cases, substantial R\&D is needed.

\section{International Boundary Aerial Drone Patrols}

The Defense Advanced Research Project Agency (DARPA) and DOD have developed a number of drones for specialized missions. Integration with renewable energy recharging is very difficult, however, and represents the forefront of technology development today. On-station airships represent the ultimate goal of these efforts. Using this technology, an observation platform remains above the specified zone for up to one year using renewable energy provided by PV and sufficient energy storage provided by fuel cells and batteries. Unfortunately, the required energy densities for storage and generation do not yet exist; thus more fundamental development efforts are needed. As discussed, it might be possible to use rectenna technology to transmit power to the airship, thus decreasing the weight required for power generation and energy storage sufficiently to enable this type of surveillance platform. Similarly, a drone that lands on the water for recharging is a very advanced system that might or might not be possible to create using the technology presently available.

In general, existing batteries can provide a first step in design and testing, and can be only a small part of subsequent energy storage options that utilize the higher energy densities achievable with fuel cells. Reversible fuel cells that produce hydrogen and also provide power still are developmental. That said, the integration of electrolyzers and fuel cells for this application will not work due to the extra weight.

As discussed above, DHS can work with researchers and industry to develop batteries with potentially higher energy densities than that of fuel cells with the hydrogen storage systems. Additionally, as discussed in the fuel cell section, NREL is working with industrial partners to 
develop reversible solid-oxide based fuel cells that generate hydrogen or methane and also provide electricity from hydrogen or methane. This work could be leveraged for DHS goals. This type of reversible-fuel-cell system can produce and use hydrocarbon fuels that have much higher storage system energy densities than can be achieved with hydrogen, and also provide highquality heat that when combined with a microturbine can produce energy efficiencies of more than $80 \%$. Both technologies substantially increase the overall power-system energy density, thus enabling longer flight times between recharging. DHS can work with partners to develop new revolutionary batteries and reversible-fuel-cell systems with the goal of attaining energy densities of more than $1,000 \mathrm{Wh} / \mathrm{kg}$, as needed to enable continuous or long-time monitoring of international boundaries via aerial drones.

\subsubsection{Wireless Energy Transfer}

Wireless energy transfer enables the powering of devices or the recharging of batteries without the power supply having to physically contact the devices consuming the power. One advantage this type of transfer such is that it keeps the device's location covert. Other advantages include potentially reducing the labor involved in retrieving or digging-up devices to change-out batteries or replenish liquid fuel. Another is reducing the need for oxygen to burn liquid fuels, thus minimizing the accompanying heat signatures.

\section{Technology Overview}

For any type of wireless energy-transfer technology, important factors that must be considered include the quantity of energy to be transferred, how fast the transfer must be, and how far away from the receivers the transmitter is located. Also important is the types and quantities of media that the energy must travel through (i.e., air, water, clouds, dry soil, wet soil). To obtain a good, integrated solution additional questions should be considered, such as the following.

- Is there opportunity to improve the efficiency of the operating device's power consumption?

- What is the capacity of the receiving device's battery storage?

- What time interval between recharging is desirable to maintain the stealth and the effectiveness of the receiving devices?

- How small must the device be?

- How small must the associated energy receiving component be?

A number of different technologies have been proposed to wirelessly transfer energy. Presently, the most viable include rectennas, inductive coupling, and laser transfer. Each of these technologies is at a different stage of development and commercialization.

\section{Rectenna Energy Transfer-Technology Overview}

Rectenna is the abbreviated name given to rectifying antennas. A rectenna is an antenna which can receive electromagnetic (EM) radiation of various different types (i.e., signals from commercial radio stations, microwaves, and radar) and convert it to DC electricity. Rectennas generally are tuned to one specific type of radiation. Because EM radiation occurs as a wave form it can be rectified or restructured into DC current using an electronic device called a rectifier. This is accomplished in the same way that alternating current-which also occurs as a wave form — can be rectified and restructured into direct current. 
A rectenna is a receiver only and requires a transmitter to produce the original EM radiation (energy) that is received by the rectenna. That transmitter can be powered by a nonrenewable power source, such as the utility grid or a diesel generator, or by clean power source such as a PV panel, wind turbine, or fuel cell.

An advantage of rectenna technology is that, depending on the type, size, and power of the transmitters and receivers, power can be sent from a transmitter to a rectenna over a long or short distance without having any physical contact with the rectenna-possibly even without being in the direct line of sight of the rectenna. This would allow covert sensors to be powered or batteries recharged without revealing the device's exact location. Disadvantages include creating radio-frequency interference, and the potential for energy loss in the transfer process.

\section{State of Rectenna Technology}

There is a long history of rectenna research and prototype devices. NASA has investigated the use of rectenna technology for many years, hoping to one day use it to transmit energy generated by solar PV panels in low earth orbit down to the earth's surface. Although they do not transmit energy, several technologies nonetheless utilize principles similar to rectenna. One of the bestknown examples of commercialized rectenna technology is the radio frequency identification (RFID) chip. These chips increasingly are being substituted for bar codes as a wireless way of transferring information about items being transported and sold. Ground-penetrating radar also is worth mentioning because it transmits information via EM radiation through soil media.

Currently, there are very few (if any) commercial products using rectenna technology to transmit energy.

\section{Department of Homeland Security Relevance: Wireless Energy Transfer}

These technologies are significant because they allow the repowering of hidden detection sensors (e.g., buried seismic sensors) while keeping the locations of these sensors relatively covert during the recharging process.

\section{Today's Opportunities}

No off-the-shelf technologies currently are available for wireless energy transfer.

\section{Tomorrow's Potential}

Transmitters could be integrated into a vehicle — such as a Humvee — and driven near buried sensors to recharge the sensor battery without needing to dig it up, thus keeping buried-sensor locations covert. Areas of research include the following.

- Work with manufacturers to develop a prototype transmitter and rectenna receiver that could receive power for ground-buried sensors.

- Work with manufacturers to develop a prototype transmitter that could be transported and effectively integrated covertly into a vehicle.

- Investigate the dampening effects that various soils might have on the efficiency of transmitting power from an aboveground transmitter to a buried receiver connected to a sensing device.

\section{Long-Term Applications and Research}

Drones could be equipped with repeaters that could relay power transmitted from far away locations to the sites of the sensors. Alternatively, it also might be possible-depending on the 
power needed - to incorporate a power source and transmitter directly into a drone. Research is needed in the areas of micro-EM transmitters, receivers, and relays that could be utilized on drones to transmit or relay power to buried devices. These devices possibly could double as communications signal relays to extend the range of communications equipment for DHS personnel working covertly in the field.

\section{Inductive Coupling Energy Transfer-Technology Overview}

Inductive coupling works using the same principle as a transformer. Electrical current flowing through a coil of wire creates a magnetic field. If that magnetic field is placed close to another coil of wire, then the magnetic field in the first coil of wire creates a magnetic field in the second coil of wire, which also "induces" electrical current flow in the second coil of wire. Current applications include the wireless charging of batteries for cell phones and laptops by laying them on top of special charging mats, as well as the wireless charging of batteries for medical implants and electric vehicles. Advantages of this technology are that it is relatively mature, relatively efficient, and inexpensive as compared to other wireless energy-transfer technologies. A disadvantage of this technology is that the power source coil must be in very close proximity (possibly directly on the soil above a buried unit).

\section{Department of Homeland Security Relevance: Inductive Coupling Energy Transfer Today's Opportunities \\ Transmitters could be integrated into a vehicle and driven over buried sensors to recharge the sensor battery without digging up the sensor. This method, however, would require the transmitter to be precisely on top of the sensor, thus compromising its location to some degree.}

\section{Laser Energy Transfer-Technology Overview}

Laser energy transfer is a concept very similar to the rectenna, except that it uses a laser beam instead of EM radiation to transmit the energy. This concept has been proposed for transmitting electricity from PV arrays orbiting the earth directly to a receiver on earth. Advantages of this technology include the ability to transmit power over long distances in a very narrow beam cross section accurately, and the lack of any radio-frequency noise. Disadvantages of this technology include the need for a direct line of sight to transmit the power, the energy inefficiency of the process, the absorption of light by the atmosphere, and the relative lack of commercial products.

\section{Department of Homeland Security Relevance: Laser Energy Transfer}

No DHS applications have been determined for this wireless technology at present.

\section{Thermoelectric Technologies-Technology Overview}

Thermoelectric devices typically are solid-state devices with no moving parts, which create an electric current when exposed to a temperature difference on opposite sides of the device. Typically, this means that one side of the device must be cold and the other side hot. There are three separately identified effects that produce this result, the Pelier, the Seebeck, and the Thompson effects. Additionally, changing the sides of the device that are heated and cooled changes the direction of current flow. Alternatively, heat can be moved from one side of the device to the other side by actively running current through the device, thus producing a cooling effect. An advantage is the ability to use low-level heat to generate power. A disadvantage is the potential for the energy source to create a heat signature that could be detected by infrared goggles. 


\section{State of Heat-Driven Technologies}

Heat-driven devices have been in use for years. They initially were utilized by NASA, which used small nuclear reactors on satellites to create heat which then used a thermoelectric device to create electricity. More recently these devices have been used to cool electronics and to create miniature solid-state refrigerators and heaters for use in cars. Recently, there has been a resurgence of research on these devices in an attempt to improve the net energy efficiency of automobiles by converting some of their waste heat into electricity.

\section{Department of Homeland Security Relevance: Thermoelectric Technologies}

These devices could be used to power buried sensors using only the temperature difference between the sun-heated surface soil and the consistent $\sim 50^{\circ} \mathrm{F}\left(10^{\circ} \mathrm{C}\right)$ lower ground temperature. Additionally, during the winter nighttime temperatures can reverse and dip to less than $50^{\circ} \mathrm{F}$ creating a temperature difference in the opposite direction, and creating a current flow. By adding a power converter, this opposite-direction current flow could be used to continue to generate power to charge a battery at night. During times of the day when there is no difference between the temperature at the surface and the temperature in the deep soil no charging would take place.

\section{Today's Opportunities}

A manufacturer currently is producing units which utilize the difference between the surface temperature and deep ground temperature to generate power. This unit should be compared with the power requirements of existing ground sensors to determine whether they could provide enough power to operate the heat-driven device.

\section{Tomorrow's Potential}

It might be possible to work with manufacturers to develop custom versions of the off-the-shelf products presently available. These would operate more efficiently and improve off-the-shelf opportunities. Areas of research include the following.

- Determine whether there is a discernable heat signature associated with these units that could be picked up with infrared technology and, if so, whether there is a way to disguise the heat signature.

- Work with sensor manufacturers to develop an integrated design to reduce the power required by the sensors so that it could be powered by the ambient-temperature differences.

- Create a hybrid unit that can be powered by ambient-temperature differences most of the time and then recharged via a rectenna intermittently or more often if the sensor failure started to occur more frequently in a particular area.

- Determine whether different types of soils (indistinguishable from normal indigenous soils) which could harvest, store, and conduct sunlight and heat more efficiently could be found or developed to improve the power-generating capacity of thermoelectric devices.

- Determine how seasonal temperature and moisture differences would affect the power generation. 


\subsubsection{Fuel Cells}

A fuel cell is a device that creates uses hydrogen or hydrogen-rich fuel and oxygen to create electricity. Fuel cells are more energy efficient than combustion engines, and the hydrogen used to power them can come from a variety of sources. If pure hydrogen is used as a fuel, then fuel cells emit only heat and water, thus eliminating concerns about air pollutants or GHGs. Figure 5 shows many types of fuel cells and their diverse applications.

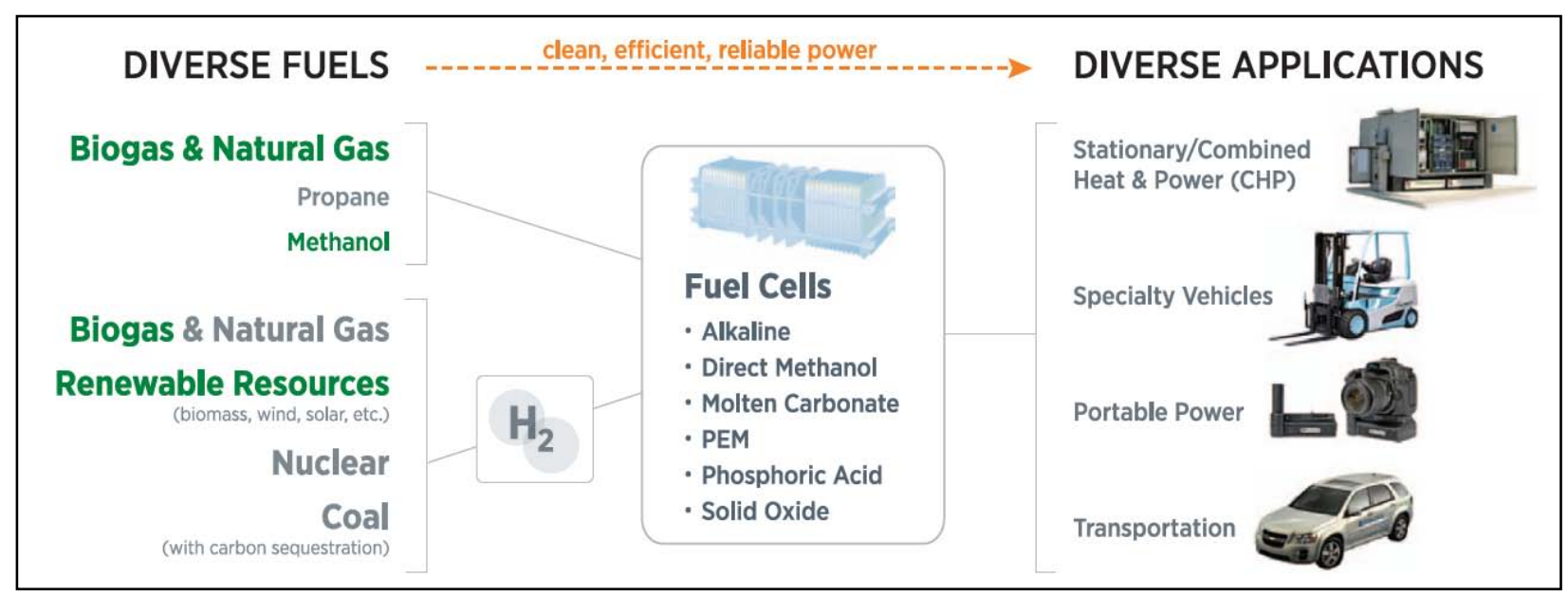

Figure 5. Fuel cell types, fuels, and applications. Illustration from DOE

\section{Technology Overview}

A fuel-cell system is made up of several key components that can include:

- Fuel delivery module (from a fuel processor or a hydrogen storage tank)

- Fuel cell stack

- Balance of plant

- Power electronics module

- Control system.

The fuel-delivery module governs the delivery of hydrogen to the fuel-cell stack and is needed in most fuel-cell installations. Hydrogen is produced and purified on demand for the fuel-cell system by a fuel processor. The fuel processor converts the fuel supply (e.g., natural gas, biogas) into a hydrogen-rich stream, which is purified to an acceptable level for the fuel-cell stack. Maintaining the required hydrogen purity is critical in these systems. Certain contaminants in the fuel supply act as poisons to the fuel-cell stack and drastically shorten the lifetime of the fuel-cell system. As discussed below, there are several types of fuel-cell designs. The hydrogen purity specification varies for different designs. Hydrogen also can be delivered and stored on-site in a tank to power the fuel-cell system.

The electrochemical process of converting hydrogen into electricity and heat occurs in the fuelcell stack. The stack is surrounded by various other plant components (e.g., valves, air blowers, sensors), and monitors and regulates system operation. Hydrogen is fed into the anode side of the 
fuel-cell stack and air is fed to the cathode side of the stack to sustain the electrochemical reaction. An illustration of this reaction can be seen in Figure $6 .{ }^{4}$

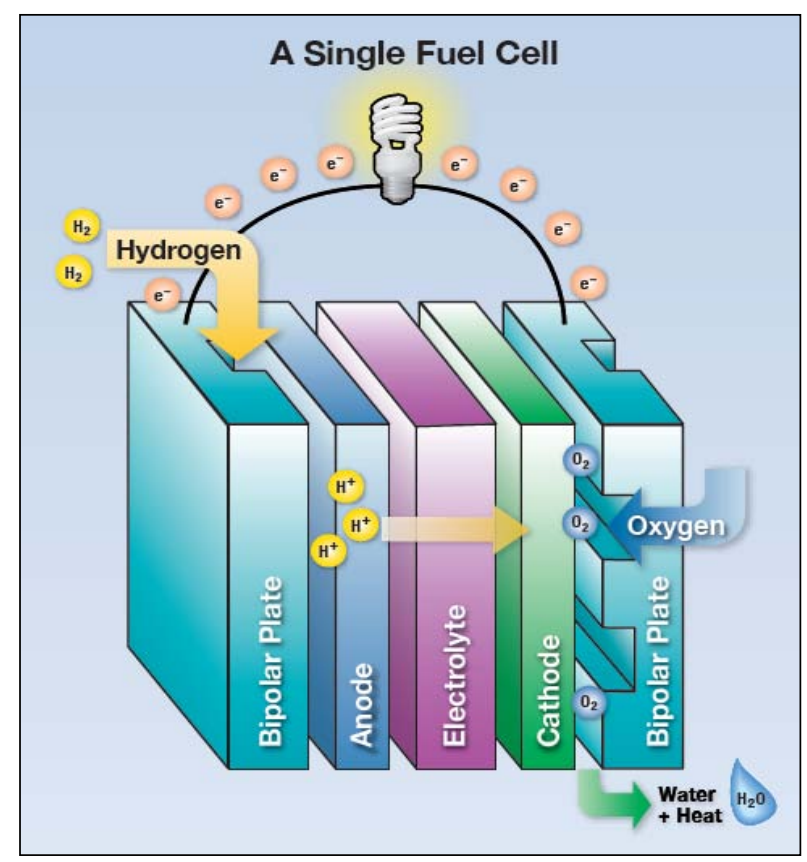

Figure 6. Fuel cell basics. Illustration from DOE

DC electricity is produced by the fuel cell. A power electronics module typically is incorporated into the fuel-cell system design to manage the power output and quality from the fuel-cell system. If the end user requires $\mathrm{AC}$ output, then the conversion from $\mathrm{DC}$ to $\mathrm{AC}$ power is accomplished in the power electronics module. DC to DC power conversion also is employed in some applications (e.g., telecom backup material handling equipment). A control system is used to operate the entire fuel-cell system and typically interfaces with the electrical system at the customer site and provides remote telemetry of the fuel cell operation.

\section{Fuel Cell Types, Efficiencies, Costs, Status of Deployment (Megawatts Installed)}

The installed cost of a fuel cell system depends on the type of fuel-cell system selected, its configuration, and its size. Cost information is obtained by contacting a fuel-cell manufacturer. The Fuel Cell Power Model $^{5}$ can be used to perform a preliminary evaluation of using fuel cells at the site location. Installed costs for a fuel-cell system can range from $\$ 5,000 / \mathrm{kW}$ to $\$ 10,000 / \mathrm{kW}$, and include purchase, warrantee, transportation, installation, connection, and commissioning. A fuel cell operates like a battery, except that it can provide continuous power. Instead of requiring charging, this electrochemical device uses oxygen and a readily replenished fuel such as hydrogen to produce electricity. Individual fuel cells are stacked in a module to produce the desired energy output, much like commercial batteries use an array of individual cells. Heat and water are the primary byproducts, therefore fuel cells are virtually pollution free and have more than twice the efficiency of traditional combustion technologies; typically ranging from $40 \%$ to $65 \%$. When fuel cells are deployed in an automobile, fuel economy of 36 to 52

\footnotetext{
${ }^{4}$ In addition, an animation of this reaction is available at www.eere.energy.gov/hydrogenandfuelcells/fuelcell_animation.html

${ }_{5}^{5}$ Available at www.hydrogen.energy.gov/ fc power_analysis.html
} 
miles per gallon of gasoline equivalent is typical (NREL 2010). Energy in the form of heat and electricity is produced as long as fuel is supplied to the fuel cell.

Fuel cells can provide power for a range of applications, from laptop computers to utility power plants. A power converter can convert the DC power produced by the fuel cell into AC power that is compatible for use by both consumer and industrial customers. When the heat from the fuel cell is captured and used in combination with the electrical power (combined heat and power, CHP), fuel cells have efficiency rates of between $70 \%$ and $85 \%$. Table 2 provides a comparison of the various fuel cell technologies. ${ }^{6}$

Table 2. Comparison of Fuel Cell Technologies. Table from DOE

\begin{tabular}{|c|c|c|c|c|c|c|c|c|}
\hline $\begin{array}{l}\text { Fuel Cell } \\
\text { Type }\end{array}$ & $\begin{array}{l}\text { Common } \\
\text { Electrolyte }\end{array}$ & $\begin{array}{l}\text { Common } \\
\text { Fuels }\end{array}$ & $\begin{array}{l}\text { Operating } \\
\text { Temperature }\end{array}$ & $\begin{array}{l}\text { Typical } \\
\text { Stack } \\
\text { Size }\end{array}$ & Efficiency & Applications & Advantages & Disadvantages \\
\hline $\begin{array}{l}\text { Polymer } \\
\text { Electrolyte } \\
\text { Membrane } \\
\text { (PEM) }\end{array}$ & $\begin{array}{l}\text { Perfluoro } \\
\text { sulfonic } \\
\text { acid }\end{array}$ & $\begin{array}{l}\text { Hydrogen, } \\
\text { Methanol, } \\
\text { Biomethanol }\end{array}$ & $\begin{array}{l}50-100^{\circ} \mathrm{C} \\
122-212^{\circ} \\
\text { typically } 80^{\circ} \mathrm{C}\end{array}$ & $\begin{array}{l}<1 \mathrm{~kW}- \\
100 \mathrm{~kW}\end{array}$ & $\begin{array}{l}60 \% \text { trans- } \\
\text { portation } \\
35 \% \\
\text { stationary }\end{array}$ & $\begin{array}{ll}\text { - } & \text { Backup } \\
& \text { power } \\
\text { - } & \text { Portable } \\
\text { power } \\
\text { - } \text { Distributed } \\
\text { generation } \\
\text { - Transport- } \\
\text { ation } \\
\text { - Specialty } \\
\text { vehicles }\end{array}$ & $\begin{array}{l}\text { - Solid electrolyte } \\
\text { reduces corrosion } \\
\text { and electrolyte } \\
\text { management } \\
\text { problems } \\
\text { - Low temperature } \\
\text { - Quick start-up }\end{array}$ & $\begin{array}{l}\text { - Expensive } \\
\text { catalysts } \\
\text { - Sensitive to fuel } \\
\text { impurities } \\
\text { - Low temperature } \\
\text { waste heat }\end{array}$ \\
\hline $\begin{array}{l}\text { Alkaline } \\
\text { (AFC) }\end{array}$ & $\begin{array}{l}\text { Aqueous } \\
\text { solution of } \\
\text { potassium } \\
\text { hydroxide } \\
\text { soaked in a } \\
\text { matrix }\end{array}$ & Hydrogen & $\begin{array}{l}90-100^{\circ} \mathrm{C} \\
194-212^{\circ} \mathrm{F}\end{array}$ & $\begin{array}{l}10-100 \\
k W\end{array}$ & $60 \%$ & $\begin{array}{l}\text { - Military } \\
\text { - Space }\end{array}$ & $\begin{array}{l}\text { - Cathode reaction } \\
\text { faster in alkaline } \\
\text { electrolyte, leads } \\
\text { to high } \\
\text { performance } \\
\text { - Low-cost } \\
\text { components }\end{array}$ & $\begin{array}{l}\text { - Sensitive to } \mathrm{CO}_{2} \\
\text { in fuel and air } \\
\text { - Electrolyte } \\
\text { management }\end{array}$ \\
\hline $\begin{array}{l}\text { Phosphoric } \\
\text { Acid } \\
\text { (PAFC) }\end{array}$ & $\begin{array}{l}\text { Phosphoric } \\
\text { acid } \\
\text { soaked in a } \\
\text { matrix }\end{array}$ & $\begin{array}{l}\text { Hydrogen, } \\
\text { Natural Gas, } \\
\text { Biogas }\end{array}$ & $\begin{array}{l}150-200^{\circ} \mathrm{C} \\
302-392^{\circ} \mathrm{F}\end{array}$ & $\begin{array}{l}400 \mathrm{~kW} \\
100 \mathrm{~kW} \\
\text { module }\end{array}$ & $40 \%$ & $\begin{array}{l}\text { Distributed } \\
\text { generation }\end{array}$ & $\begin{array}{l}\text { - Higher } \\
\text { temperature } \\
\text { enables CHP } \\
\text { - Increased } \\
\text { tolerance to fuel } \\
\text { impurities } \\
\end{array}$ & $\begin{array}{l}\text { - Pt catalyst } \\
\text { - Long start-up time } \\
\text { - Low current and } \\
\text { power }\end{array}$ \\
\hline $\begin{array}{l}\text { Molten } \\
\text { Carbonate } \\
\text { (MCFC) }\end{array}$ & $\begin{array}{l}\text { Solution of } \\
\text { lithium, } \\
\text { sodium, } \\
\text { and/or } \\
\text { potassium } \\
\text { carbonates, } \\
\text { soaked in a } \\
\text { matrix } \\
\end{array}$ & $\begin{array}{l}\text { Natural Gas, } \\
\text { Biogas }\end{array}$ & $\begin{array}{l}600-700^{\circ} \mathrm{C} \\
1112-1292^{\circ} \mathrm{F}\end{array}$ & $\begin{array}{l}300 \mathrm{~kW}- \\
3 \mathrm{MW} \\
300 \mathrm{~kW} \\
\text { module }\end{array}$ & $45-50 \%$ & $\begin{array}{ll}\text { - } & \text { Electric } \\
& \text { utility } \\
\text { - } & \text { Distributed } \\
\text { generation }\end{array}$ & $\begin{array}{l}\text { - High efficiency } \\
\text { - Fuel flexibility } \\
\text { - Can use a variety } \\
\text { of catalysts } \\
\text { - Suitable for CHP }\end{array}$ & $\begin{array}{l}\text { - High temperature } \\
\text { corrosion and } \\
\text { breakdown of cell } \\
\text { components } \\
\text { - Long start-up time } \\
\text { - Low power } \\
\text { density }\end{array}$ \\
\hline $\begin{array}{l}\text { Solid Oxide } \\
\text { (SOFC) }\end{array}$ & $\begin{array}{l}\text { Yttria } \\
\text { stabilized } \\
\text { zirconia }\end{array}$ & $\begin{array}{l}\text { Natural Gas, } \\
\text { Biogas }\end{array}$ & $\begin{array}{l}700-1000^{\circ} \mathrm{C} \\
1202-1832^{\circ} \mathrm{F}\end{array}$ & $\begin{array}{l}1 \mathrm{~kW}-2 \\
\mathrm{MW}\end{array}$ & $60 \%$ & $\begin{array}{ll}\text { - } & \text { Auxiliary } \\
\text { power } \\
\text { - Electric } \\
\text { utility } \\
\text { - Distributed } \\
\text { generation }\end{array}$ & $\begin{array}{l}\text { - High efficiency } \\
\text { - Fuel flexibility } \\
\text { - Can use a variety } \\
\text { of catalysts } \\
\text { - Solid electrolyte } \\
\text { - Suitable for CHP } \\
\text { and CHHP } \\
\text { - Hybrid/GT cycle }\end{array}$ & $\begin{array}{l}\text { - High temperature } \\
\text { corrosion and } \\
\text { breakdown of cell } \\
\text { components } \\
\text { - High temperature } \\
\text { operation requires } \\
\text { long start-up time } \\
\text { and limits }\end{array}$ \\
\hline
\end{tabular}

One advantage of fuel cells is that hydrogen fuel can be derived using a variety of domestic resources such as biomass, water, natural gas, propane, and methanol. Hydrogen generated by

\footnotetext{
${ }^{6}$ For a list of commercially available fuel cell technologies, see www.fuelcells.org/usfccproductlist.pdf
} 
water electrolysis - the splitting of water molecules into hydrogen and oxygen using electricity - can be beneficial when used in combination with variable renewable-energy technologies such as solar and wind. When the electricity used for water electrolysis is produced by a variable renewable-energy source, the hydrogen stores the unused energy for later use and is classified as a renewable fuel and energy resource.

The largest markets for fuel cells today are stationary power, portable power, auxiliary power units, and forklifts. Fuel-cell deployment statistics are as follows.

- Approximately 75,000 fuel cells have been shipped worldwide

- Approximately 24,000 fuel cells were shipped in 2009 (a more than 40\% increase from 2008 numbers)

- Approximately 50 new large $(>10 \mathrm{~kW})$ fuel cells were installed in 2009, and a 4.8-MW fuel cell will be installed in the new World Trade Center in New York City

- More than 1,500 fuel cell systems have been sold into the North American material-handling market to power forklifts

- More than 1,000 fuel cells providing combined heat and power for residences are being demonstrated in Japan (the program plans to demonstrate more than 3,000 units)

- Some stationary fuel cells are available with 80,000-hour warranties on the stack, and some manufacturers report about 40,000 hours between major overhauls.

Fuel cells offer the following benefits.

- High efficiencies for energy conversion

○ Approximately $40 \%$ to $50 \%$ electrical efficiency (lower heating value [LHV] of hydrogen)

○ $80 \%$ or greater overall efficiency, including utilization of waste heat

- Indefinite operating time as long as fuel is provided

- Scalable from milliwatts to megawatts

- Emission-free operation with direct hydrogen fuel cells

- Quiet operation

- Reliability

Drawbacks of fuel-cell use include cost and lack of fuel infrastructure (i.e., production, storage, distribution).

\section{Fuel Cell Research Objectives}

The DOE Fuel Cell Technology Program addresses the key challenges facing the widespread commercialization of fuel cells. The program outlines fuel cell cost and durability targets of $\$ 750$ per $\mathrm{kW}$ and 40,000-hr durability for stationary systems and $\$ 30$ per $\mathrm{kW}$ and 5,000-hr durability for vehicles. There is a proposed hydrogen cost target of approximately $\$ 6$ per gallon gas equivalent (dispensed and untaxed). The target for fuel cell range is over 300 miles for vehicles without compromising interior space or performance. DOE is also working on safety, codes and standards development, creation of a domestic manufacturing and supplier base, public awareness and acceptance of fuel cells, and the development hydrogen supply and delivery infrastructure. 
Research is also ongoing in currently non-commercially available fuel cell technologies, including microbial fuel cells and tri-generation fuel cell concept. ${ }^{7}$

\section{Department of Homeland Security Relevance: Fuel Cell Applications}

\section{Today's Opportunities}

Fuel cells and hydrogen can play an important role in U.S. energy strategy, with the potential for use in a broad range of applications. This section highlights the commercially available applications as identified during the site visits, and is divided into the categories of backup power systems, remote power stations, and portable power.

\section{Backup Power Systems}

Fuel-cell systems can be price-comparable with traditional technologies such as coal and oil when the fuel-cell systems provide added value through quiet operation, increased efficiency, and reduced GHG emissions. Companies currently offering commercial backup power fuel cell systems include, but are not limited to, the following.

- IdaTech, LLC (www.idatech.com)

- Altergy Systems (www.altergy.com)

- Relion (www.relion-inc.com)

- Hydrogenics (www.hydrogenics.com/fuel/ups)

- Intelligent Energy (www.intelligent-energy.com/products and services/fuel cells/ power_systems/)

- Dantherm-Power (www.dantherm-power.com/Products/Backup_power.aspx $)$

- ClearEdge Power (www.clearedgepower.com/)

These commercial fuel cell backup power systems are applicable to the following applications.

- Communications systems on mountaintops

- Power quality at facilities with grid power

\section{Remote Power Stations}

Fuel-cell systems are a good option for providing power in remote locations because they have fuel flexibility and can be configured to provide heat and power-supply needs. They are currently used for telecommunication towers, homes, mobile lighting, and emergency communications.

Remote power stations are applicable to the following applications.

- Stadium lighting

- Portable light towers

- Portable remote operating stations

- Communications systems on mountaintops

Commercially available remote power systems include, but are not limited to, the following.

\footnotetext{
${ }^{7}$ More information is available at www.eere.energy.gov/hydrogenandfuelcells/pdfs/program_plan2010.pdf
} 
- Multiquip (www.multiquip.com)

- Trenergi (www.trenergi.com/aboutus.htm)

- Dantherm-Power (www.dantherm-power.com/Products/Backup_power.aspx)

- ClearEdge Power (www.clearedgepower.com/)

\section{Portable Power Systems}

Portable fuel-cell power systems are available for military, emergency, and recreational applications. The operational advantages offered by these systems relative to traditional generator systems include reduced weight, low acoustic signatures, extended run times, increased energy density, increased efficiency, and reduced emissions. Companies currently offering portable fuel-cell power systems include, but are not limited to, the following.

- Protonex (www.protonex.com)

- Ultracell (www.ultracellpower.com)

- Adaptive Materials, Inc. (www.adaptivematerials.com)

- SFC Energy (www.sfc.com/en/)

- Oorja Protonics (www.oorjaprotonics.com)

- IRD Fuel Cell Technology (www.ird.dk/index.php)

- MTI MicroFuel Cells (www.mtimicrofuelcells.com/)

- Lilliputian (www.lilliputiansystemsinc.com/)

- Angstrom Power (www.angstrompower.com/)

- Jadoo Power (www.jadoopower.com/)

These portable fuel-cell power systems would be applicable to following applications identified by DHS.

- Recharging and powering handheld devices

- Recharging and powering equipment at remote locations

- Seismic sensors

\section{Renewable Energy Storage Solutions}

NREL is working with different companies to efficiently convert renewable energy from wind and solar to hydrogen. NREL is also developing reversible fuel cell technologies that could be integrated with renewable energy to provide the direct energy storage needed with wind and solar, while with the same unit providing the power when the renewable energy is no longer available. This potentially decreases cost and weight, but substantial development is required to provide durable fuel cells that can provide both hydrogen generation and electricity for thousands of cycles. Furthermore, while PEM fuel cells may be developed for this application, the higher potential efficiencies of SOFCs may also be leveraged.

\section{Tomorrow's Potential}

\section{Handheld Devices (1 W to $100 \mathrm{~W}$ )}

A leading area for DOE-funded hydrogen storage research is performing catalyst research for direct methanol fuel cells (DMFC) and proton-exchange membrane fuel cells (PEMFC) to improve their performance and durability. DHS can leverage NREL's fuel-cell program with 
DOE to power the DHS security mission. Most DMFCs are designed for consumer applications such as laptops, cell phones, and sensors. There also are DMFC systems that have been developed specifically to power portable devices of U.S. soldiers. These are funded by DOD (the U.S. Army Research Office, DARPA, and the Army's Communications-Electronics Research, Development and Engineering Center [CERDEC]), thus there is a potential for collaboration with DOD and the companies that developed DMFCs as power sources and battery chargers for these applications. NREL has collaborated and continues to collaborate with portable-power companies such as MTI MicroFuel Cells and Ultracell.

Direct methanol fuel cells are very well suited for powering or charging batteries that power handheld devices such as night-vision devices. The DMFCs are small, light, and have high energy capacity. They are especially suited for long-term operations that batteries cannot fulfill. The liquid-methanol fuel is easy to handle, light, and safe to use as a fuel cartridge. The highenergy fuel provides high energy density in a small package. The DMFC technology presently is available as both commercial and demonstration products. A pilot project using this technology to power or charge hand-held devices for DHS needs now is possible.

Alkaline membrane fuel cells (AMFCs) also are being developed by DOD for soldier power needs. This technology is not as developed as that of DMFCs, but it has great cost benefits because relatively inexpensive non-precious metals can be used as catalysts. NREL also is conducting research in this field for DOE Basic Energy Science (BES) and recently put together a workshop on AMFCs for DOE EERE. DHS again can leverage the research and development funded by DOE for homeland security applications.

\section{Catalyst Research and Development (3 to 5 Years)}

Wide commercialization of DMFCs currently is limited by the performance and durability of the anode catalyst. DOE is developing a fuel-cell catalyst that potentially can produce ten times the performance of other state-of-the art DMFCs - at a lower catalyst loading and greater catalyst durability. This can translate to lower cost and lighter, smaller DMFC systems that can provide long operating times. Depending on the specific DHS power needs and size, weight, and capacity requirements, a DMFC system can be produced that will meet DHS security mission needs.

\section{Remote Operations (Less than $5 \mathrm{~kW}$ )}

The DMFCs and AMFCs producing power have been demonstrated. Oorja Protonics has a commercial 1-kW DMFC system that charges the lead-acid batteries in forklifts. CellEra has a 2-kW hydrogen-air AMFC system that uses non-precious metals as catalysts and is targeted for backup power applications. Systems such as these can be used to remotely charge batteries and equipment.

\section{Long-Term Applications and Research Handheld Devices (1 W to $100 \mathrm{~W}$ )}

Another key area for research and development assistance is on more durable, high-temperature membranes and non-precious catalysis for AMFCs. These are the two major barriers to commercialization of this technology. Currently, AMFCs use hydrogen as a fuel; however, other fuels - such methanol, ethanol, hydrazine, and dimethyl ether - can be used. The problem with carbonaceous fuel is that carbon dioxide is formed and can react with the hydroxide and harm the 
fuel cell. High-temperature membrane and catalysis research can alleviate this problem and make AMFC more viable.

To identify and remedy areas of vulnerability in U.S. border security, DHS can tap into NREL's wide collaborative network of other national laboratories, industry, and academia that are conducting research, development, testing, and evaluation of fuel-cell and hydrogen technologies. As an example, NREL is working with different companies to efficiently convert renewable energy from wind and solar to hydrogen. NREL also is developing reversible fuel-cell technologies that could be integrated with renewable energy to provide the direct energy storage needed with wind and solar, with the same unit providing the power when the renewable energy no longer is available. This potentially decreases cost and weight, but substantial development is required to provide durable fuel cells that can provide both hydrogen generation and electricity for thousands of cycles. Furthermore, although PEM fuel cells might be developed for this application, the greater potential efficiencies of solid oxide fuel cells (SOFCs) also can be leveraged.

\subsection{Marine and Hydrokinetic Energy Technologies}

Marine and hydrokinetic energy can be broadly categorized as wave energy, tidal current, openocean current, river current, and ocean thermal gradient. Salinity gradient energy often is included as a form of marine energy. The technologies used to convert these forms of energy to electricity often are referred to collectively as marine hydrokinetic (MHK) energy technologies. A brief introduction to MHK technologies and their current status is provided in this section. Also included is a more in-depth exploration of the scientific, technical, and nontechnical challenges and barriers to their wide-spread use. This second section, called "Roadmap to Address Commercial Pathway and Challenges for Marine Hydrokinetic Technologies" (page 47), will inform DHS in terms of how fast mainstream MHK technologies are moving, and how this might impact DHS applications. The reader may choose to bypass this discussion and skip to the "Department of Homeland Security Relevance: Marine Hydrokinetic Energy" section starting on page 56.

Marine hydrokinetic-energy generation technologies have been under development since the 1976 oil embargo, but this development has been sporadic and inconsistent. Only prototypes and early production models have been deployed as

demonstration projects. The current state of the industry can be compared to the early stages of the wind energy industry in the 1980s. Many concepts have been proposed with a wide variety of methods for energy capture and conversion but there has been little technology convergence. Dozens of

MHK Technology Status

Today the development status of MHK technology is comparable to the wind industry in the 1980s.

companies are trying to deploy these technologies around the world.

\section{Marine Hydrokinetic Energy Technologies Overview}

Many MHK concepts have been proposed with a variety of methods for energy capture and conversion. There are more than 100 concepts in various stages of development in 24 countries around the world (Khan and Bhuyan 2009). In the United States alone, there are at least $40 \mathrm{MHK}$ 
concepts currently being developed; however, there is little convergence of the technology, indicating that no particular technology or configuration has yet been shown to be superior. Figure 7 illustrates general types and numbers of technology concepts under development worldwide and their current development status.

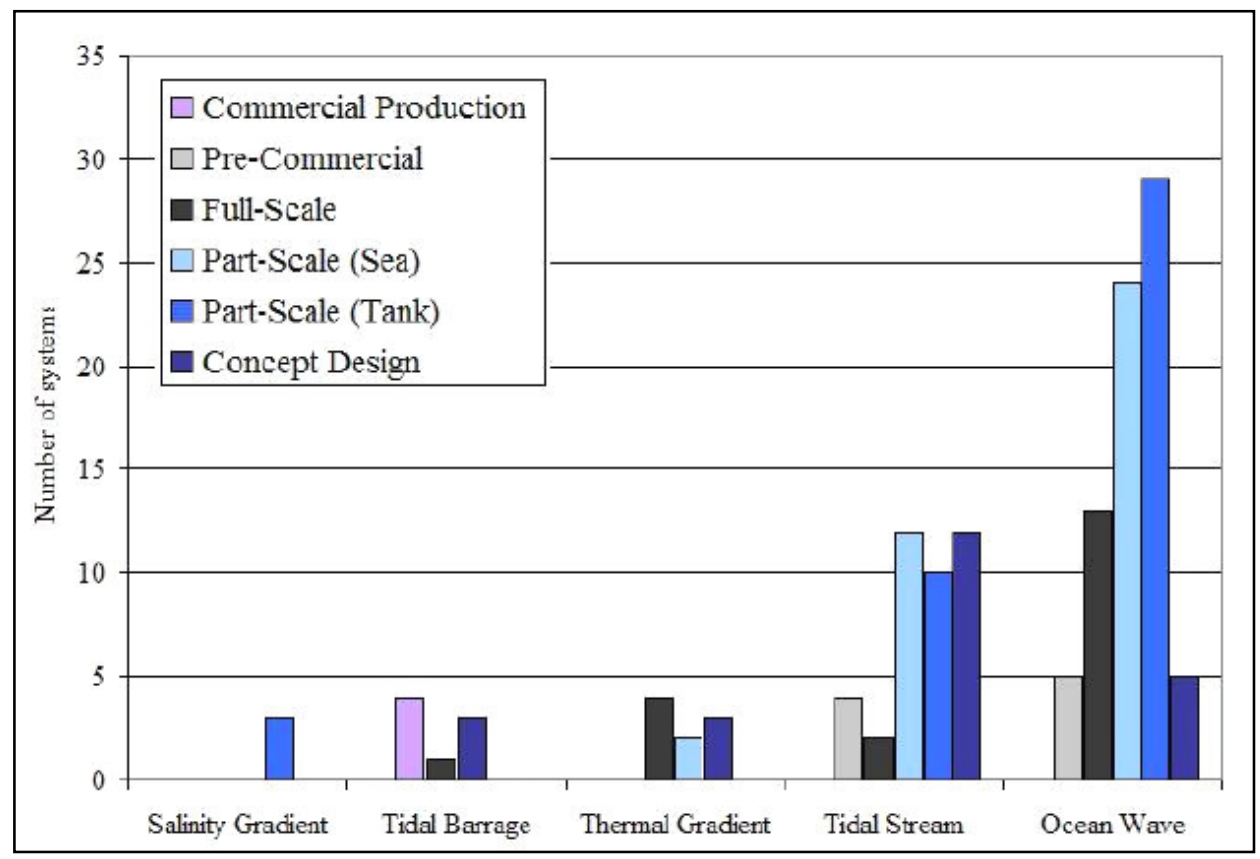

Figure 7. Marine hydrokinetic technologies in development worldwide (Khan and Bhuyan 2009)

Figure 7 includes the tidal-barrage concept, which usually is not considered to be a marine hydrokinetic technology. Tidal barrages are dam structures built across the mouth of an estuary that has a high tidal range. The barrage is conceptually identical to a conventional hydroelectric dam on a river except that the barrage or dam can generate power during incoming and outgoing tides. Barrage systems are not be considered further here because they already are commercial, and therefore they are not included in the family of MHK technologies. Figure 7 groups tidalcurrent devices and ocean-current devices into one category for convenience. Many tidal devices also are being proposed for ocean-current applications; they would use modified supporting structures, foundations, or mooring arrangements. Figure 7 clearly indicates that most of the development is in the area of ocean wave and tidal- and ocean-current technologies - which is why this report focuses on these technologies. There is growing interest, however, in ocean gradient energy, often called ocean thermal energy gradient (OTEC), and salinity gradient energy conversion. These technologies are not considered in this report because they have not yet been tested at a practical commercial-prototype scale. The International Energy Agency's Ocean Energy Systems Implementing Agreement (IEA-OES) Annual Report 2010 presents a comprehensive report of global activities for all of the marine energy technologies. ${ }^{8}$

The following sections describe the configurations for the major device types of conversion technologies for wave- and water-current energy converters. A comprehensive listing of marine

\footnotetext{
${ }^{8}$ Also available at www.iea-oceans.org/_fich/6/2010_Annual_Report.pdf
} 
and hydrokinetic device configurations, current projects, and development companies is provided in the Marine and Hydrokinetic Technology Database on the DOE website (DOE 2011). ${ }^{9}$

\section{Wave-Energy Conversion Technologies}

The wave-energy converters currently deployed or under development can be described as absorbers, attenuators, oscillating water columns, overtopping devices, and inverted pendulums. These all are defined below.

- Absorbers extract energy from the movement of a buoy - relative to the ocean floor - with the rise and fall of waves. This movement is converted to electrical energy via either a linear or a rotary generator.

- Attenuators capture wave-energy using a principal axis that is oriented parallel to the direction of the incoming wave. These devices convert the energy created by the relative motion of the articulated bodies of the devices as waves pass along them.

- Oscillating water columns are partially submerged enclosed structures. Air fills a chamber in the upper part of the structure which is above the water level. Incoming waves are funneled into the structure from below the waterline, causing the water column within the structure to rise and fall with the wave motion. This alternately pressurizes and depressurizes the air in the chamber, pushing and pulling it through an air turbine mounted in a portal in the top of the chamber structure.

- Overtopping devices allow waves to lift water over a barrier to fill a reservoir that is drained through a hydro turbine. These often are described as low-head hydro facilities because they convert the potential energy of the elevated water in the upper reservoir to generate powermuch like a conventional hydropower dam.

- Inverted-pendulum devices use the surge motion of waves to rotate a large, hinged paddle back and forth. The flapping motion drives hydraulic pumps that, in turn, drive electrical generators. Alternatively, linear generators are used to directly convert the wave energy into electrical energy.

Schematics of several of these (generic) devices are presented in Figure 8. The technology status of wave energy converters is thoroughly reviewed in Bedard (2006), Falcao (2010), and Khan and Bhuyan (2009). More-detailed information also is provided in these sources.

\footnotetext{
${ }^{9}$ Also available at www.eere.energy.gov/windandhydro/hydrokinetic/default.asp
} 

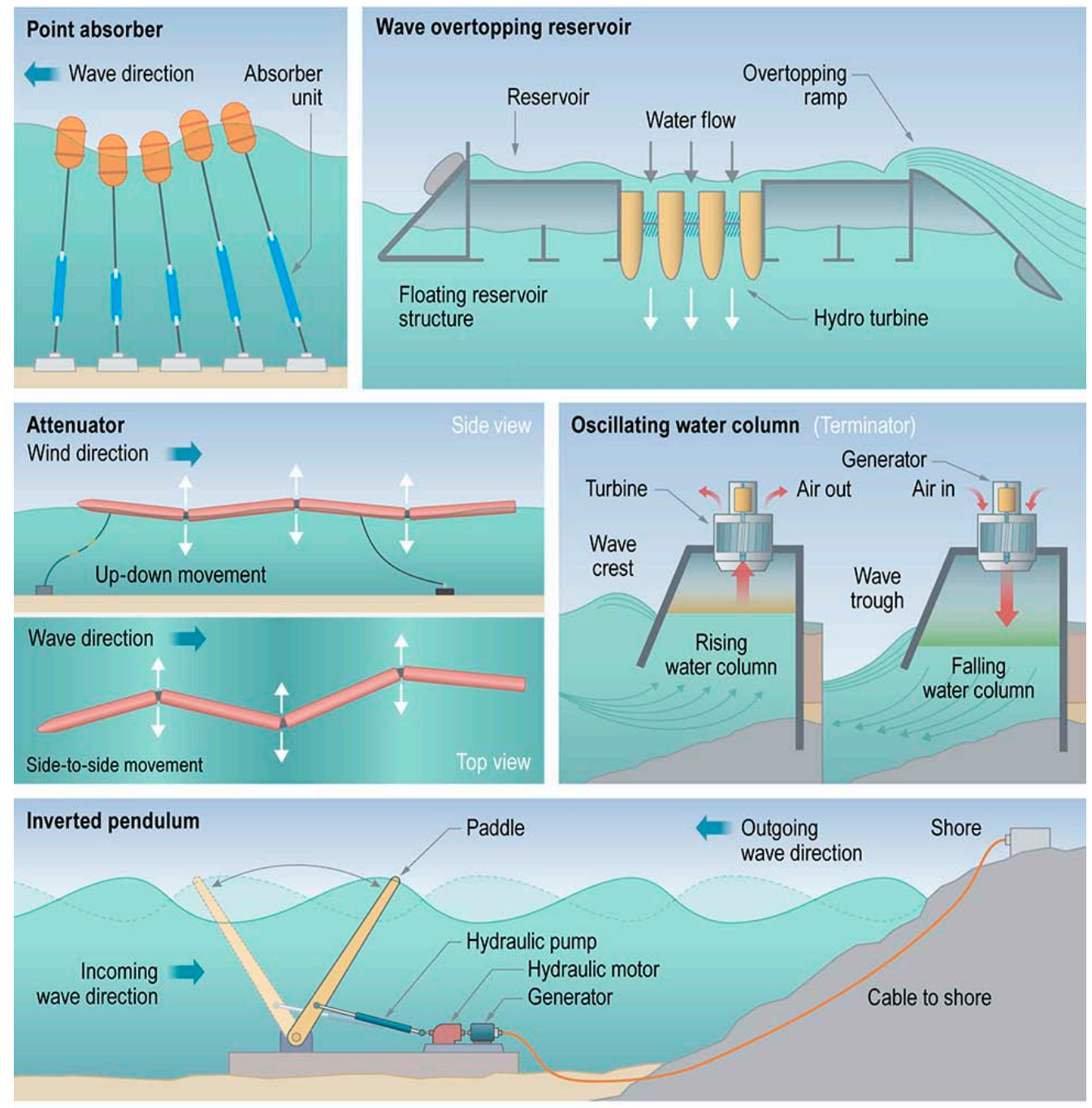

Figure 8. Five typical wave-energy conversion devices (adapted from Bedard 2006). Illustration by NREL

\section{Tidal, Open-Ocean, and River-Current Hydrokinetic Technologies}

Tidal energy potentially can be converted to electrical energy through water height differences or through the kinetic energy created when alternating tides and geography induce water flows. A tidal barrage converts potential energy to electrical energy by allowing large reservoirs to fill during high tide, and then releasing the water through conventional hydropower turbines during low tide. Tidal, ocean-current, and river-current turbines convert the kinetic energy in flowing water into electricity in exactly the same manner that a wind turbine converts the kinetic energy in wind into electricity. The status of tidal energy technology is reviewed in Bedard (2006) and Khan and Bhuyan (2009).

Figure 9 illustrates four common tidal-energy devices, an axial-flow horizontal-axis turbine; a cross-flow vertical-axis turbine; an articulated oscillating hydrofoil generator; and a Venturi augmented axial-flow, horizontal-axis turbine. In general, these devices can be shrouded or unshrouded, and the rotation axis can be either horizontal or vertical. 

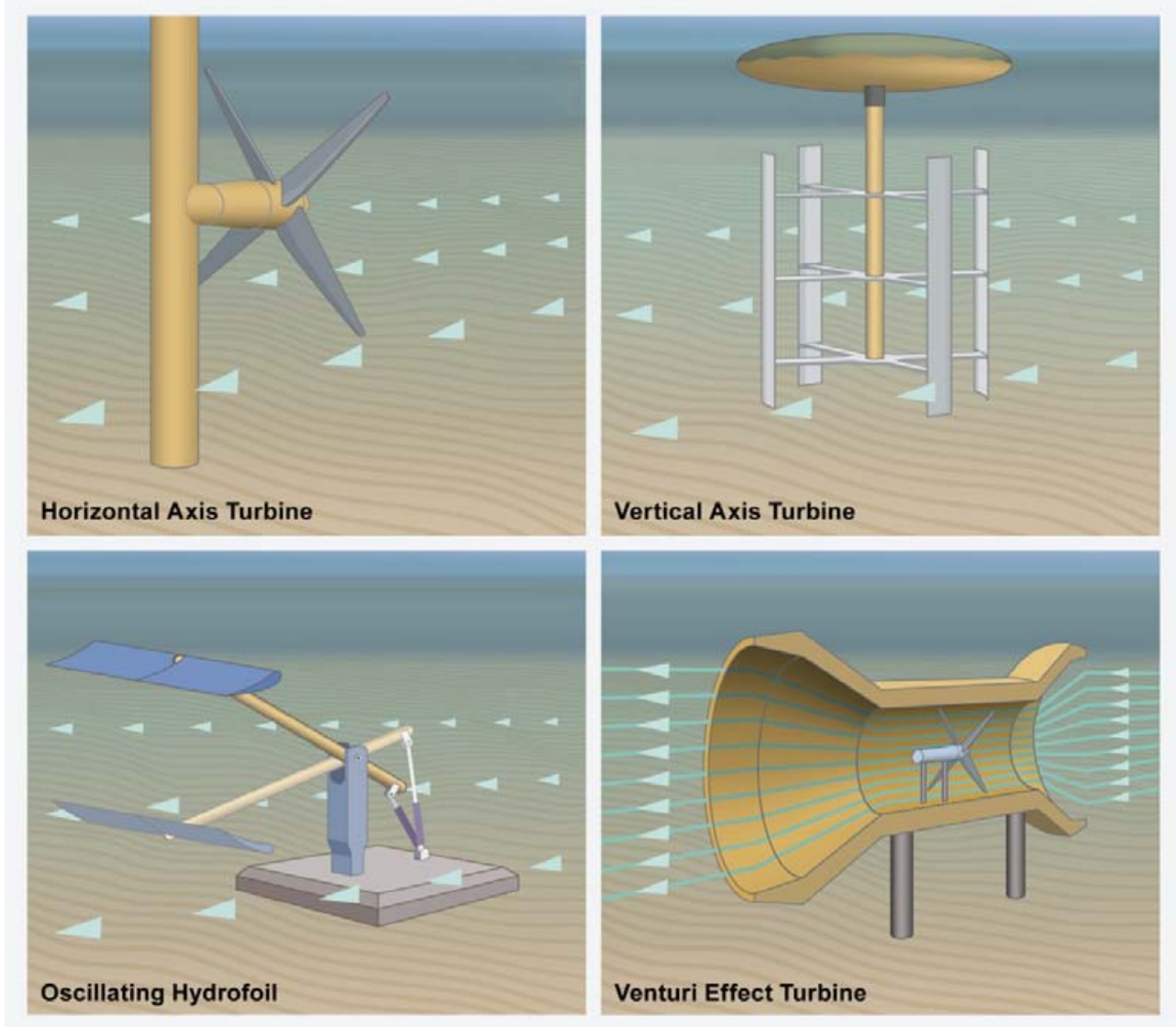

Figure 9. Four typical kinetic-energy conversion devices for tidal, ocean, and river currents (adapted from Bedard 2006). IIlustration by NREL

\section{Marine Hydrokinetic Energy Resource Availability}

Assessing the available resources for MHK technologies is a difficult and complex task. Each of the different technologies involves a distinctly different technical discipline and requires estimating different physical variables in the natural environment. For devices that extract energy from tidal, ocean currents, and river flows, the quantity of interest is the velocity field and its time history. For wave devices, the time history of the wave height is of primary interest. For ocean thermal-energy converters, interest lies in the temperature difference between the surface waters and waters at depth; this temperature difference is used to run a heat engine to generate electricity. Salinity gradient energy devices make use of the energy released from the mixing of saltwater and freshwater. This depends on the concentration of salt and the availability of a freshwater source, and most of these quantities are not well documented historically. For example, tidal flows always have been of great interest to seafarers, but generally it is the range of tidal heights that is of interest and not the velocity field; there is little historical data on tidal velocities to support kinetic energy estimates.

Resource estimates often are separated into two distinct quantities. The first quantity of interest is the kinetic energy in the natural flow at a particular location, such as at a river cross section, a tidal estuary cross section, or the wave energy along a length of coastline at some distance from shore. The kinetic energy contained in the natural flow ( $\mathrm{kWh} /$ year) is the energy moving through a 
particular cross section of an estuary or channel. Alternatively, often the kinetic power density $\left(\mathrm{kW} / \mathrm{m}^{2}\right)$ of the flow at a location is assessed, and then integration of the kinetic power density over time and the cross-sectional area will give the total energy at the cross section for the year. The kinetic energy and the kinetic power density are quantities that provide an estimate of the amount of energy that is present in the natural environment, and sometimes are referred to as theoretical potential, gross potential, or natural resource potential. This type of estimate for the natural kinetic energy resource gives insight into the geographic locations of high levels of natural resources, and an estimate of the spatial extent and quality of those resources. Figure 10 illustrates the location and approximate level of wave, tidal, and current resources in the United States.

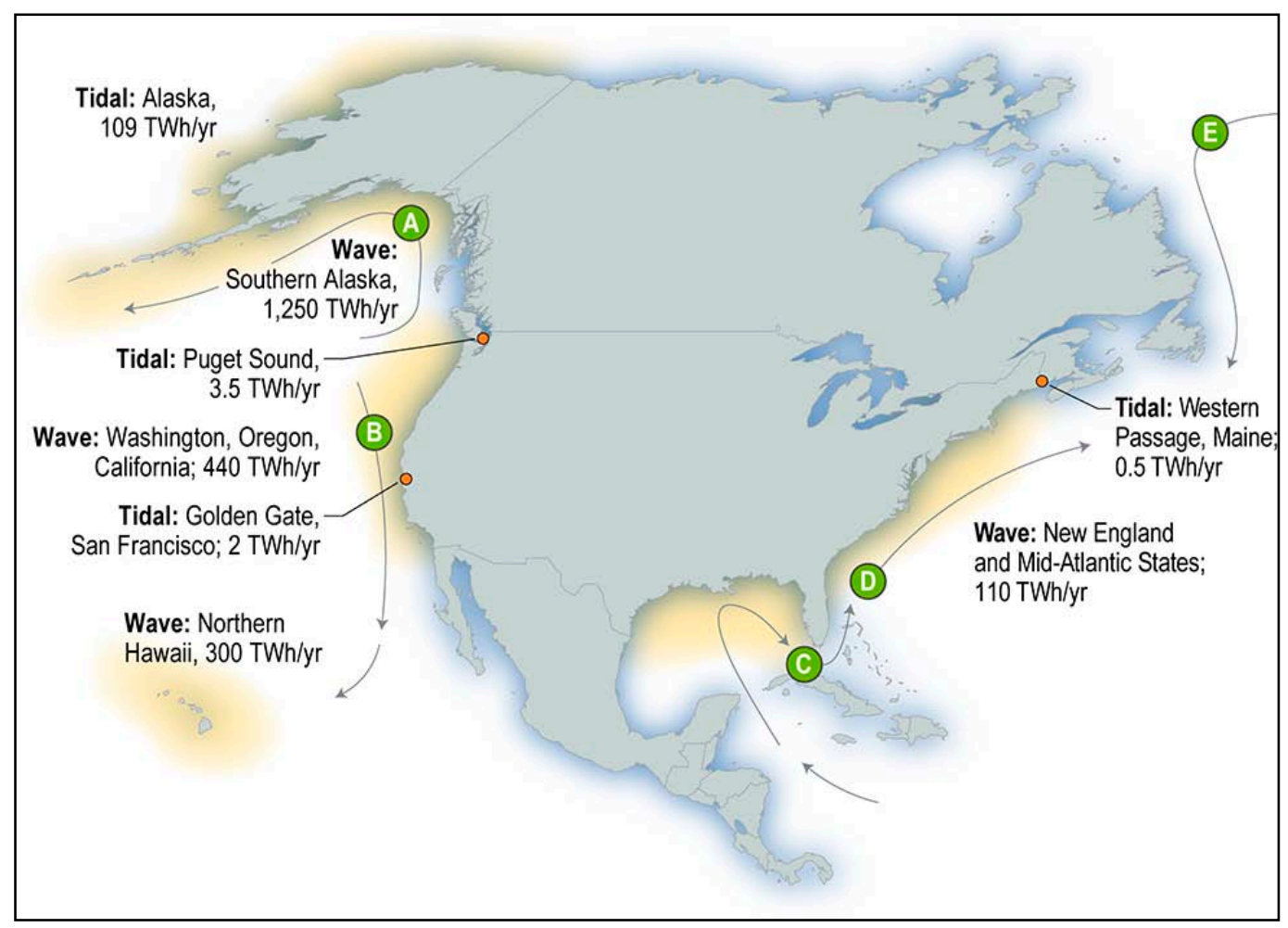

Figure 10. Total natural tidal-current energy and wave energy resources in United States; A: Alaska current, B: California current, C: Florida current, D: Gulf Stream, E: Labrador current (adapted from Bedard 2008). Illustration by NREL

The second resource quantity of interest is the amount of the specific natural resource that can be extracted practically. Estimating the natural resource is difficult, but estimating the practically extractable resource is even more difficult. In most cases, the practically extractable resource cannot be directly derived from an estimate of the natural resource alone. This occurs because the amount of extractable resource can be changed by the introduction of the energy-extraction device into the flow. Generally, it is expected that introducing the device consequently reduces the amount of energy that can be extracted from the flow, but this is not always the case. The interaction of a device with the natural physical flow at a site changes the physics of the flow and - depending on the flow constraints - this can either increase or decrease the extractable energy. Additionally, environmental policies and laws that require no significant environmental impacts, plus any other usage restrictions (such as fishing and shipping lanes), almost always reduce the possible level of extraction at a particular site. 
Table 3 summarizes the potential extractable U.S. ocean renewable resources that, at present, only have been crudely assessed. There is considerable uncertainty in these estimates, and the extractable limits are based on rough engineering assumptions that have not been verified with real-world test data. In fact, the methodology for estimating the tidal resources is not fully developed at this time. For that reason, the estimates in Table 3 probably represent a lower boundary for the actual tidal resources. They are reported here simply to provide an understanding of the current status of MHK resource assessment, and to demonstrate that additional research is needed. It also should be noted that Table 3 was developed with commercial bulk power generation in mind, and small energy demands (several watt-hours to a few kilowatt-hours) can be generated with only minimal resources and using relatively small devices, but the cost will be quite high as compared to conventional electric utility sources.

Table 3. Summary of Currently Available Estimates for Wave and Current Energy Resources

\begin{tabular}{|l|c|c|c|}
\hline $\begin{array}{l}\text { Energy } \\
\text { Source }\end{array}$ & Natural Resource & $\begin{array}{c}\text { Extractable Resource } \\
\text { (Existing Estimates) }\end{array}$ & Comments and Notes \\
\hline $\begin{array}{l}\text { Wave } \\
\text { Energy }\end{array}$ & $\begin{array}{c}\text { Total United States } \\
2,100 \text { terawatt-hours } \\
\text { per year (TWh/yr) }\end{array}$ & $\begin{array}{c}\text { Total United States = 260 TWh/yr } \\
\text { (67 TWh/yr excluding Alaska } \\
\text { and Hawaii) }\end{array}$ & $\begin{array}{c}\text { Based on Bedard (2007) data and } \\
\text { rough engineering assumptions } \\
\text { for extraction potential }\end{array}$ \\
\hline $\begin{array}{l}\text { Tidal } \\
\text { Current }\end{array}$ & $\begin{array}{c}\text { Unknown } \\
\text { (115 TWh/yr for 3 sites } \\
\text { including Alaska) }\end{array}$ & $\begin{array}{c}\text { U.S. estimate incomplete } \\
\text { (6 TWh/yr for 3 sites, } \\
\text { excluding Alaska) }\end{array}$ & $\begin{array}{c}\text { Based on few sites from Bedard } \\
\text { (2007) and engineering } \\
\text { assumptions for extraction } \\
\text { potential }\end{array}$ \\
\hline $\begin{array}{l}\text { Ocean } \\
\text { Current }\end{array}$ & $\begin{array}{c}175 \text { TWh/yr } \\
\text { (Florida current only) }\end{array}$ & $\begin{array}{c}21 \text { TWh/yr (Florida current only) } \\
\text { Based on Hanson (2010) for } \\
\text { Florida current, and Bedard }\end{array}$ \\
\hline
\end{tabular}

\section{Marine Hydrokinetic Energy Technologies Global Deployment}

The global installed capacity of ocean energy systems is illustrated in Figure 11. The information was compiled from data provided by delegate members of the IEA-OES Implementing Agreement as listed in the 2010 Annual Report (IEA-OES 2010). Note that much of the global installed tidal-energy capacity is in the form of tidal-barrage technology which, as noted, really is conventional hydropower technology using an impoundment in a tidal estuary. 


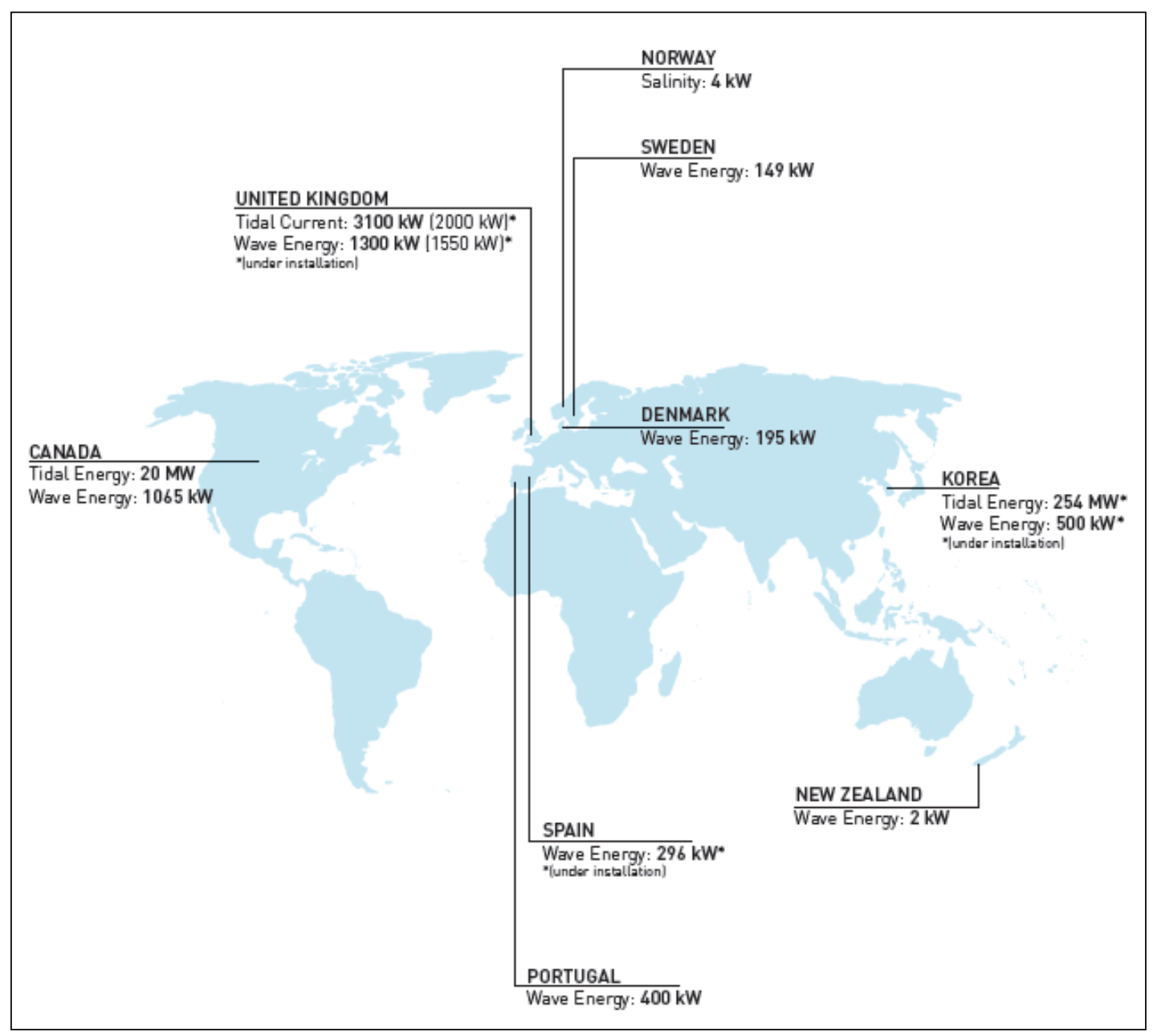

Figure 11. Global installed capacity of ocean energy technologies (IEA-OES 2010)

\section{Roadmap to Address Commercial Pathway and Challenges for Marine Hydrokinetic Technologies}

The marine hydrokinetic renewable energy stakeholders in the United States have developed a draft technology roadmap that lays out a pathway for commercialization and addresses the challenges faced by this new form of renewable energy technology. The stakeholders for this new industry include technology developers, project developers, policy makers, government regulators, investors, parts and component suppliers, consultants, environmental organizations, government and university researchers, and ocean users. These stakeholders include the groups that will be most affected by the development of this new technology. These groups will supply the skilled workforce needed to manufacture and install the facilities, and their communities will host the facilities in nearby public waters. This roadmap is a working document, which means that it will evolve over time and will be updated as knowledge of these technologies and the environment in which they are deployed increases. Changes in policies, public perceptions, and energy economics also are likely to modify the roadmap's pathways and time frames. The classes of energy-conversion technologies included in the industry MHK roadmap are wave, tidal and river current, ocean thermal energy, and osmotic energy. 
The Elements of the United States Roadmap

The U.S. roadmap is based on the following four main elements.

- Vision Statement: The vision statement provides a destination for the roadmap - a picture of the desired future outcome. In this case, the vision is a picture of the MHK industry and its accomplishments by 2030 .

- Deployment Scenario: The deployment scenario provides one possible pathway by which the MHK industry could evolve to fulfill the vision.

- Commercial Strategy: The commercial strategy provides pathways to achieve the deployment scenario and to overcome barriers to commercialization of the technologies.

- Technical Strategy: The technical strategy provides pathways to address the research and development issues that must be solved to achieve the commercial strategy, mobilize the deployment, and reach the envisioned goal by 2030.

The Roadmap Vision

The stakeholders developed the following vision statement as a challenging target for the MHK industry to achieve by 2030 .

- To establish a commercially viable marine renewable energy industry that is supplied by a robust U.S. manufacturing chain, generates domestic jobs, and competes on a level playing field with other energy sources to serve both domestic and international marketplaces in 2030.

- To deploy at least 20 gigawatts $(\mathrm{GW})$ of combined marine renewable energy capacity in an economically, environmentally, and socially responsible manner by 2030 .

\section{The Development and Deployment Scenario}

The upper portion of Figure 12 illustrates the MHK technology development and deployment scenario envisioned in the U.S. Marine Hydrokinetic Roadmap. It shows a measured, sequential development process driving the technology evolution that will lead to commercial viability and the vision of $20 \mathrm{GW}$ of installed capacity by 2030 . Domestic benefits include research and development knowledge, manufacturing and supply chain development, harbor and port infrastructure development, and the creation of jobs across the nation and in coastal communities. The global environment will benefit from a new carbon-free energy source. 


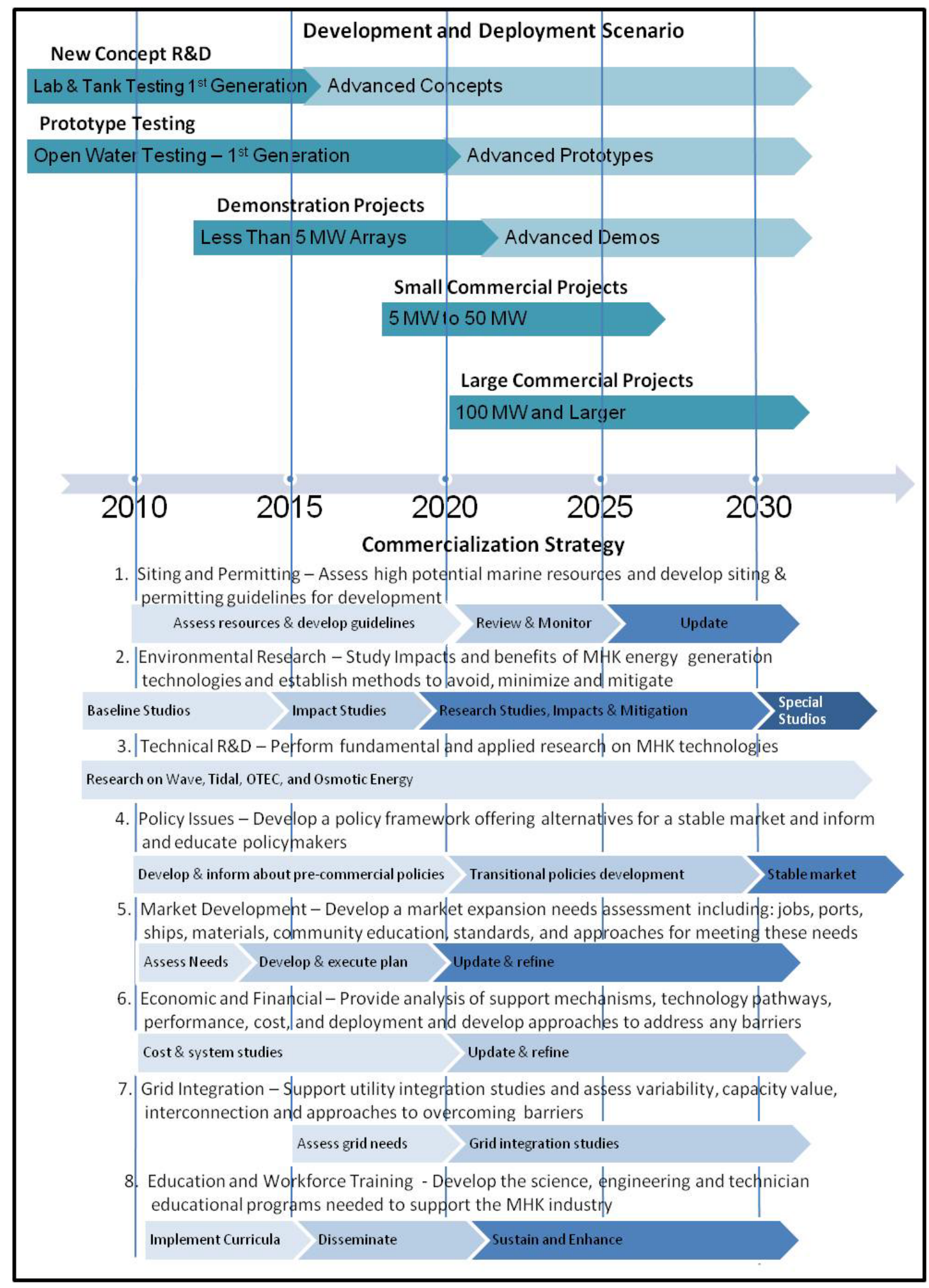

Figure 12. Development and deployment harmonized with the commercial strategy (Thresher 2010) 


\section{The Commercial Strategy}

Figure 12 shows the harmonization between the MHK development and deployment scenario and the commercialization strategy. The upper portion of the figure shows the technology development and deployment time line. The bottom portion of the figure lists eight major barriers to development and deployment and outlines strategies that address those barriers.

Figure 12 also illustrates the complex challenges that must be addressed between 2010 and 2020 for the industry to be ready to transition to full-scale commercial production and installation of large projects by 2020 . The technology must be mature enough to be installed in large quantities without major problems, and it must be priced competitively. The siting and permitting requirements must be well-established and routine; therefore, environmental-study requirements must be understood and also must be timely and affordable. Most importantly, appropriate policies and incentives must be in place to support the transition of this technology to commercial-scale production, and to facilitate the development of the market and the related supply chain, including job training and public education.

\section{The Technical Strategy}

Figure 13 illustrates the MHK development and deployment scenario together with the overall $R \& D$ technical strategy. The lower portion of Figure 13 provides a brief description of the scope of research and development for each major category of work. The arrow timelines show the types of activities that are expected to take place during each time interval. It should be understood, however, that many activities will take place simultaneously, and a number of the activities will overlap. The intent of the roadmap is to provide a logical and coordinated sequence for the primary activities that are expected to achieve the desired vision.

For the MHK device developers, the development and deployment scenario in Figure 13 shows that - from 2010 to 2015 - the primary activities are prototype testing and demonstration projects. These activities involve permitting and environmental studies, testing of machines as single units, and deploying small arrays. In the period from 2015 to 2020, efforts shift to the commercial scaling of projects and gaining operation experience in the water. Although there still will be a significant investment from 2020 to 2030 - both in developing new technology and improving existing designs - the greater investment is anticipated in scaling-up to the production and manufacture of larger projects in the 100-MW capacity range.

One of the critical activities slated for 2010 to 2015 is the development of support capabilities at U.S. test centers. For MHK devices to evolve it is critical to prove and validate performance for the machines in a real-world operating environment. Timely access to- and tailored support from - the National Marine Test Centers will enable developers to ensure that their devices have good energy capture and high reliability. After 2015, these testing capabilities must evolve with the industry - both in terms of device scale and the supporting infrastructure systems. After 2020, the test centers might need to develop a campaign for ad hoc remote testing programs at industry sites to address device-specific or site-specific issues that can occur during operation.

For other engineering and scientific contributors in the MHK industry, the major activities from 2010 to 2015 and beyond are to develop capabilities to support the initial start-up of the industry. Beyond 2030, the focus is anticipated to be driven by industry-specific technical needs based on 
the evolution of the technology. Figure 13 provides only high-level categories for anticipated R\&D activities. These are explored in more detail in the full roadmap (Thresher 2010).

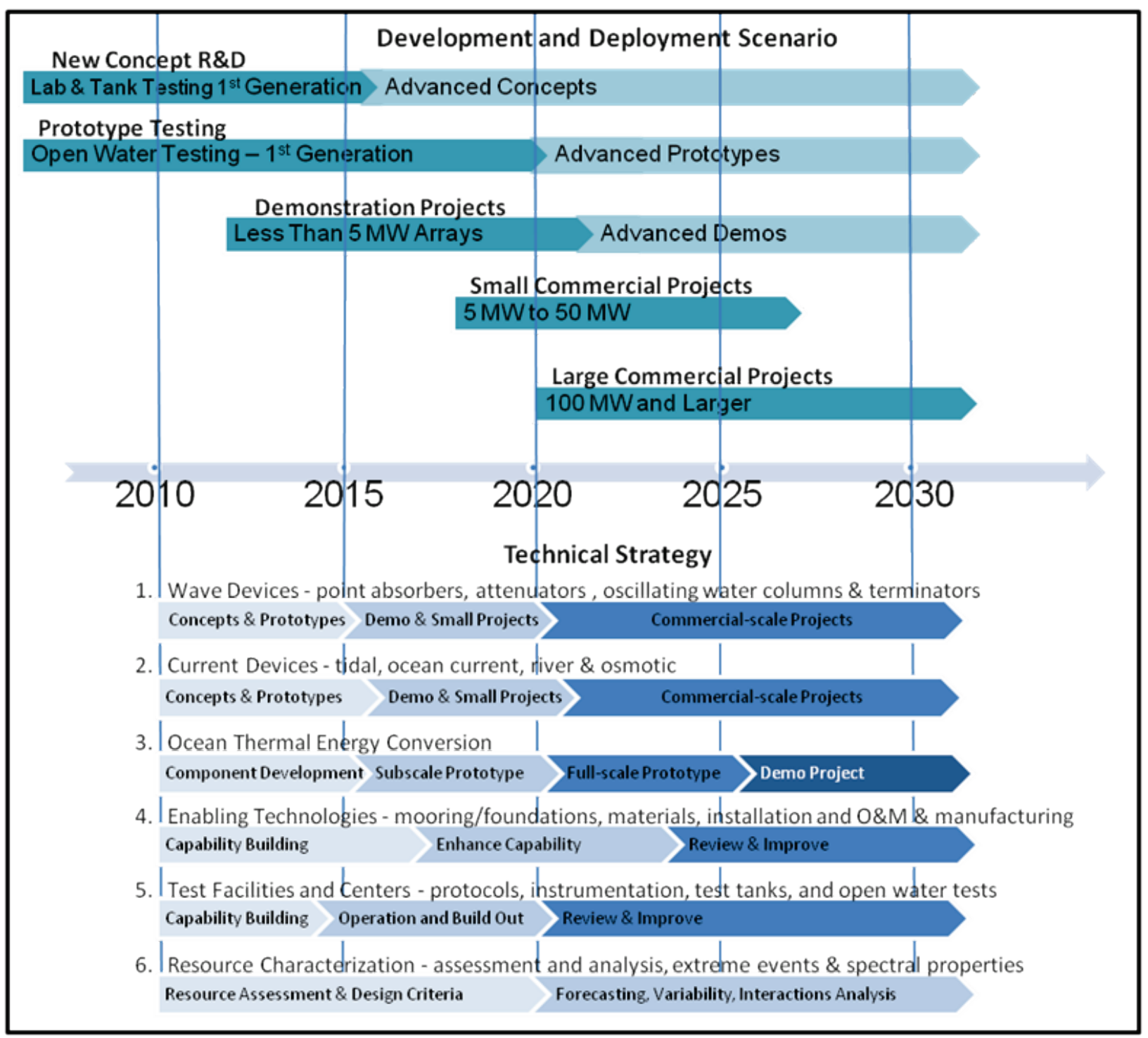

\section{Figure 13. Marine hydrokinetic development and deployment scenario and the overall R\&D technical strategy (Thresher 2010)}

Research and development of ocean energy devices can take 5 years or more from concept to ocean prototype testing, depending on complexity. A new concept always is simulated with a numerical model to gain understanding of its performance and dynamic behavior at low cost. Next, subscale tank tests are run (at one or two scales) to validate and improve the modeling. Open-ocean prototype tests are run at full scale, or near full scale, after the concept is well vetted by the models and tank testing. Lastly, a full-scale

\section{Special-Purpose Power Generators}

Over the next 5 years, the Industry will be researching and perfecting wave and tidal devices at a small to medium scale, so it is an opportune time to perform R\&D for special purpose power plants that are tailored for high reliability and operation in hostile remote environments. 
prototype is built and tested. Development of a full-scale prototype and its related testing programs only is warranted if there is a great probability of producing a superior device that can be commercialized successfully. The key research issues for ocean-energy devices focus on a single device's performance and loads and its performance in large arrays.

For wave energy to become commercial and generate significant amounts of energy, the devices must perform well in large arrays. This means that the array layout and spacing and control strategies are of paramount importance. Additionally, the overall control of the wave-device array is of great importance. Optimizing the individual performance of a device probably will not be as important as optimizing the entire array's energy capture. System models are crucial to accurately estimate system costs and to understand the influence of device scale and array size. Reliability and survival during operation and extreme events also are important factors for the success for these technologies.

Figure 13 shows the expected timeline to develop the testing facilities and capabilities needed to support the development of all of the MHK technologies. DOE has named three new national marine test centers to support development of ocean energy technologies, listed below.

- Northwest National Marine Renewable Energy Center. Oregon State University in Corvallis and the University of Washington in Seattle are jointly running the Northwest National Marine Renewable Energy Center. The Northwest Center provides a full range of capabilities to support wave and tidal energy development for the United States.

- National Marine Renewable Energy Center of Hawaii. The University of Hawaii in Honolulu established a center to facilitate the development and implementation of commercial wave-energy systems in Hawaii and to assist the private sector in moving ocean thermal-energy conversion systems beyond proof-of-concept to precommercialization, long-term testing.

- Southeastern National Marine Renewable Energy Center. Florida Atlantic University has established a center to facilitate the development and implementation of ocean current systems and to assist in moving ocean thermal-energy conversion systems and ocean watercooling systems research through testing and commercialization.

The early emphasis is on developing test-center capabilities and infrastructure, along with associated testing protocols, sensors, and data collection methodologies. It is anticipated that the United States will need test centers that can perform open-water testing of wave, tidal, ocean current, river, and ocean thermal technologies to support all of the MHK technology development pathways. The early priority is to develop the capability to test devices in realistic open-water conditions.

\section{National Marine Test Centers}

National marine energy testing centers have been established by DOE, and can be used to operationally test and prove prototype power-generation systems. These centers have cooperative research agreements with NREL for technical support and advice. 
The full roadmap contains detailed figures that illustrate the research strategy for wave, tidal, and river current devices; enabling technologies; testing facilities; resource characterization; and environmental research. It also provides a complete picture of the technical challenges in each technology area (Thresher 2010).

\section{Cost of Marine Hydrokinetic Technologies}

A public-domain analysis of wave and tidal energy-generation technology costs for existing prototype devices was performed and then described in the 2006 Carbon Trust Report (Callaghan and Boud 2006). This report provides a cost range for the 2006 prototypes and firstproduction wave and tidal-stream energy devices. This report gave the costs in 2006 British pounds sterling which were converted to U.S. dollars at the conversion rate of $1.78 \$ /$ British pounds sterling. These device costs are shown in Table 4 below, and illustrate the economic challenge for this new technology to become cost competitive in global energy markets.

Table 4. Estimated Capital Costs for Marine Hydrokinetic Wave and Tidal Technologies in 2006

\begin{tabular}{|l|c|c|c|}
\hline Description & $\begin{array}{c}\text { Low Cost } \\
(\$ / \mathbf{k W})\end{array}$ & $\begin{array}{c}\text { Mid Cost } \\
(\$ / \mathbf{k W})\end{array}$ & $\begin{array}{c}\text { High Cost } \\
(\$ / \mathbf{k W})\end{array}$ \\
\hline Wave Energy Device & 7,700 & 11,900 & 16,100 \\
\hline Tidal/Current Energy Device & 8,600 & 11,450 & 14,300 \\
\hline
\end{tabular}

These costs are quite high as compared to conventional fossil-based generation, and even are high as compared to other renewable technologies. Note, however, that MHK technology is a new renewable energy technology, and all of the competing renewable energy technology costs initially were just as high — or higher-when research was first initiated in the 1970s and 1980s. Land-based wind plant capital costs, for example, in the early 1980 s were about $\$ 4,500 / \mathrm{kW}$. This cost was reduced to $\$ 1,200 / \mathrm{kW}$ in 2004 (Wiser and Bolinger 2010). This represents a cost reduction by a factor of about 3.75 . Since 2004, however, all power-plant costs have increased significantly, for both wind plants and conventional technologies. In 2009, land-based wind-plant costs on average increased to about $\$ 2,000 / \mathrm{kW}$. Currently, the cost of offshore wind technology is estimated to be approximately $\$ 4,000 / \mathrm{kW}$ (Musial and Ram 2010), and offshore wind is considered to be nearly competitive at good wind sites. Therefore, if the cost of MHK technologies could be reduced by a similar factor then it would be in this competitive price range. Further costanalysis work currently is being performed by DOE and European entities such as the Carbon Trust in the United Kingdom, but results have not yet been released publicly.

\author{
Marine Hydrokinetic Cost \\ Reduction Potential \\ Marine hydrokinetic technologies are \\ high-torque low-speed energy \\ generators similar to wind turbines and \\ have a great potential for cost reduction \\ with experience over time.
}

\section{Environmental Impact Concerns}

Marine hydrokinetic technologies are new and emerging, and the significance of possible environmental effects is not well understood. Boehlert et al. (2007) reviewed the possible environmental effects of wave development. Additionally, the potential effect of wave development on marine birds has been reviewed independently (Grecian 2010), as have the potential environmental effects due to tidal development (Polagye et al. 2010). Multidisciplinary scientific research is required to develop a better understanding of the environmental implications of MHK technologies before they are widely deployed (Gill 2005; Inger et al. 2009). At this time, there is a comprehensive understanding of the range of possible 
environmental effects and interactions that could take place as MHK technologies are deployed. There also seems to be a reasonable understanding of which of these effects could potentially have high ecological significance, but there is little or no understanding of the actual impacts. This is because, globally, there are so few devices in the water to observe and measure the real impacts - which many agree is a logical next step. It generally is agreed that the potential for significant impacts is almost negligible, provided that early deployments are small and the installations are monitored appropriately.

There are concerns that it might be difficult to measure any actual impacts for single prototype and small installations due to the highly variable environment in the ocean. Currently there also are no standard monitoring protocols for MHK projects in the United States. In Europe, however, a project called EquiMar has been established to develop harmonized monitoring protocols for MHK prototype deployments. These protocols and related recommendations could serve as a starting point for study and field data collection efforts in the United States, as well as the development of U.S. protocols. Lastly, the IEA-OES recently established a new task to share environmental information among the member countries in an effort to accelerate the development of a global understanding of environmental impacts.

Studies to better understand and estimate the significance of any impacts on marine life, marine geography, recreation, cultural resources, and public safety are needed before MHK technologies can be widely deployed. The following list of environmental stressors and potential impacts is summarized from the workshops and papers described herein.

- Effects of energy-removing structures on wave height, tidal current flow patterns, and the resulting sediment transport

- Effects of electromagnetic fields on fish and marine mammals

- Interactions of MHK devices with fish and marine mammals

- Impacts of chemical emissions into the atmosphere and ocean

- Effects of introduced hard structures, including effects of fish aggregating devices (FADs) or artificial reefs

- Acoustic effects of many devices on fish and marine mammals

- Visual impacts

- Conflicts with other uses of sea space (e.g., fishing, boating, shipping, clamming, crabbing)

- Effects of installation and decommissioning

- Cumulative impacts of all these issues over time

\section{Current U.S. Department of Energy Research and Development for Marine Hydrokinetic Technologies}

The DOE Wind and Water Power Program sponsors research and development of advanced MHK technologies, with the objective of understanding their generation potential and identifying and addressing the technical and nontechnical barriers to their use. The MHK technologies supported generally include devices that capture energy from waves, tides, ocean currents, the natural flow of water in rivers, and marine thermal gradients without building new dams or diversions. In 2005, Congress passed the Energy Policy Act of 2005 and the Energy Independence and Security Act, which authorized substantial new funding to conduct research and development on marine and hydrokinetic technologies. In 2008, Congress began appropriating funding that allowed the program to fund research on MHK technologies. 
The mission of the DOE Water Power Program is to assess the potential energy extractable from domestic rivers, estuaries, and marine waters, and to assist the U.S. industry to harness MHK renewable energy resources in an environmentally sustainable and cost-effective manner. The DOE program has two major thrusts for MHK technologies. The first is technology development, and it seeks to:

- Prove device functionality and generate cost, performance, and reliability data

- Develop design codes and models necessary for system development and testing

- Ensure the necessary facilities exist to generate and collect system data

- Develop standards and models to analyze and evaluate test data.

The second thrust is to accelerate market development by:

- Quantifying the resource available, and — using technology performance and cost dataprojecting economic viability of MHK technologies

- Evaluating and minimizing key environmental risks associated with deployment of MHK projects

- Disseminating data on the technology and resource, and integrating this information into energy benefit and deployment models.

\section{Open-Water Prototype System Testing, Demonstration, and Operation}

The DOE Wind and Water Power Program supports a significant number of R\&D projects including concept studies, wave-tank testing, component development, proof-of-concept research, system-integration projects, and open-water full-scale prototype system testing. The open-water prototype system projects aim to test the newest and most advanced technology currently available in the world. Pictures of the device configurations are provided in Figure 14, Figure 15, and Figure 16. The prototype tests to be performed over the next 2 to 3 years are designed to assess the readiness of MHK technology for use in demonstration projects. Three prototype projects will be deployed in the next 1 to 2 years.

- Ocean Power Technologies, Inc. (Pennington, NJ) will deploy a full-scale 150-kW PowerBuoy system in the Oregon Territorial Sea and collect 2 years of detailed operating data. This project will obtain critical technical and cost performance data for one of the most advanced wave-energy converters in the United States.

- Ocean Renewable Power Company (ORPC) (Portland, ME) will build, install, operate, and monitor a commercial-scale array of five grid-connected TidGen Project devices on the sea floor in Cobscook Bay off Eastport, Maine, in two phases over 3 years. The project will advance ORPC's cross-flow turbine tidal-energy technology by producing a full-scale, gridconnected energy system, and will gather critical technical and cost performance data for one of the most advanced tidal-energy systems in the United States. The completed project will comprise an array of interconnected TidGen hydrokinetic energy-conversion devices, associated power electronics, and interconnection equipment into a system fully capable of commercial operation in moderate- to high-velocity tidal currents in water depths of up to 150 feet.

- Public Utility District No.1 of Snohomish County (Everett, WA) will deploy, operate, monitor, and evaluate two 10-meter diameter Open-Centre Turbines (developed and 
manufactured by OpenHydro Group Ltd.) in Admiralty Inlet of Puget Sound. The project is expected to generate $1 \mathrm{MW}$ of electrical energy during periods of peak tidal currents with an average energy output of approximately $100 \mathrm{~kW}$. This full-scale, grid-connected tidal turbine system will gather critical technical and cost performance data for one of the most advanced tidal turbine projects in the United States.

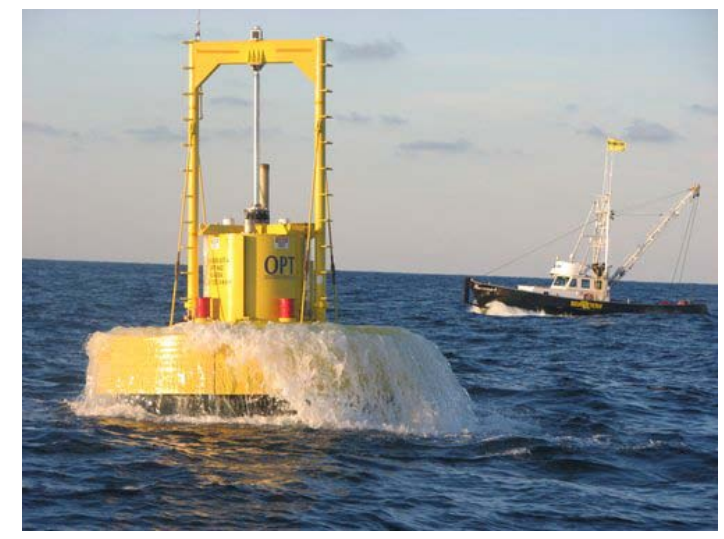

Figure 14. Ocean Power Technologies PowerBuoy wave generation system uses a "smart", oceangoing buoy to capture and convert wave energy into low-cost clean electricity.

Photo from Ocean Power Technologies, NREL/PIX 17114

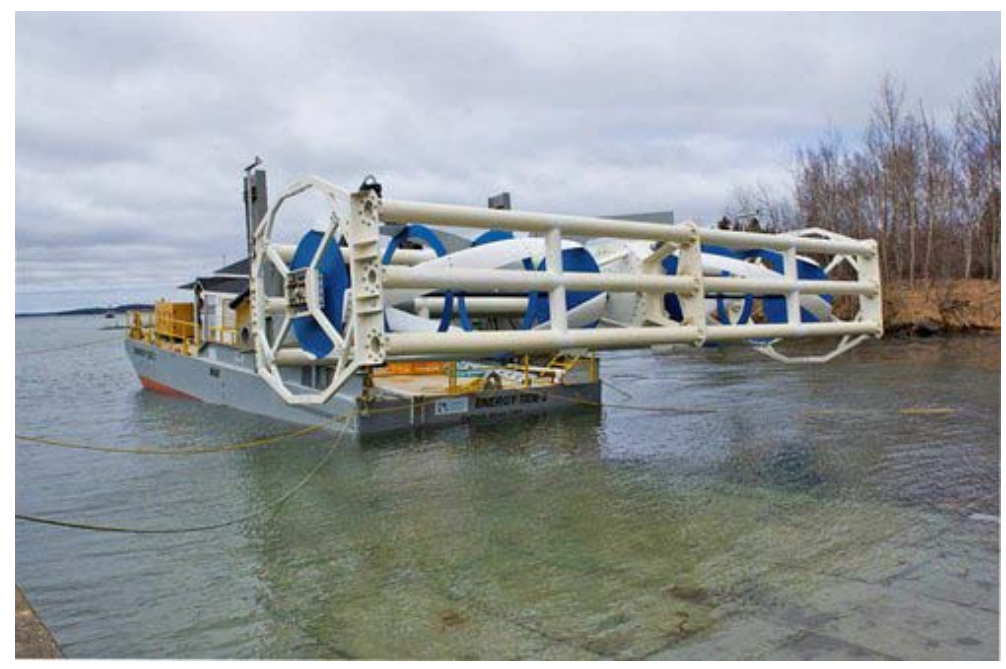

Figure 15. ORPC's Beta Turbine Generator Unit generates clean, renewable electricity by harnessing the energy of the world's rivers and oceans.

Photo from Ocean Renewable Power Company, NREL/PIX 17210 


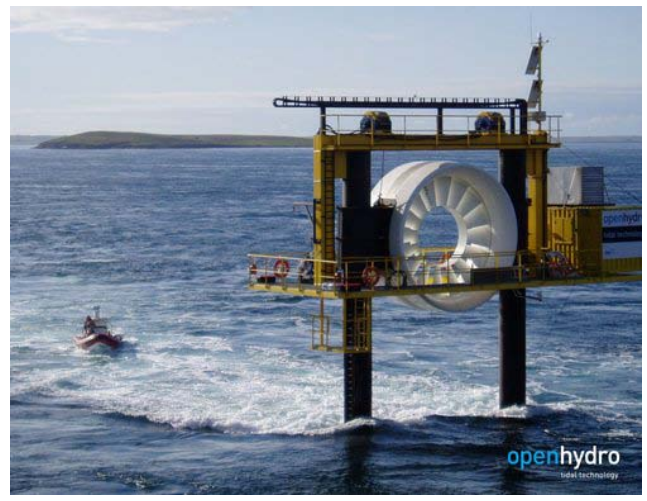

Figure 16. OpenHydro's Open-Center Turbine is designed to be deployed directly on the seabed. The first 6-m test unit produces enough energy to supply 150 average European homes and save the emission of over 450 tons of $\mathrm{CO}_{2}$ greenhouse gas per year. Photo from OpenHydro, NREL/PIX 17243

The DOE website provides additional information on the MHK technologies and a description of the R\&D projects that currently are being funded (DOE 2011).

\section{Department of Homeland Security Relevance: Marine Hydrokinetic Energy}

The DHS application of MHK renewable-energy generators would be in the area of supplying power for observational equipment and facilities located on coastal sites, on remote rivers, and for sites where other power sources are not readily accessible or are prohibitively expensive. The plan would be to provide power generators for DHS applications that would deliver electrical energy with high reliability from renewable energy sources that do not require fuel or frequent maintenance. The systems could operate unattended for long periods and could generate power for facilities, observational equipment, sensors, and transmitters employed in securing U.S. borders. These renewable-energy generation units would be tailored for specific applications and have redundant systems to assure reliable operation for lengthy periods without maintenance.

\section{Today's Opportunities and Tomorrow's Potential}

It is clear from this overview of MHK technologies that there currently are no off-the-shelf commercial products that can be applied directly to DHS applications. In the 3-to-5 year time frame, however, there is time to design, develop, and manufacture a custom product for DHS applications and to fully test it at one or more demonstration projects. As discussed, the R\&D time line for a new ocean energy generator easily can take 5 years from concept to ocean prototype testing and demonstration. To develop a new custom product it is best to first perform simulations with numerical models to gain knowledge of the expected performance and dynamic behavior and to estimate the cost. This relatively inexpensive first phase is needed to show the viability of a particular concept and to perform design trade-off studies to optimize the design prior to investing in wave-tank or water-tunnel experiments. Next, with a well-understood concept, subscale tank tests should be run at one or two different scales to verify the design concept and the numerical simulations. After the concept is well vetted by 
the modeling and tank testing, open-ocean prototype tests then would be performed at or near full scale. Proceeding to build and test a full-scale prototype only is warranted if there is a great probability that the product can successfully perform the envisioned mission role. The final step is to manufacture a small number of units for pilot-scale deployment and then track their performance and reliability over 1 to 2 years to prove the product in variety of real-world applications and in different operating environments.

NREL has managed a development program of this type for the DOE Wind Program several times over the past two decades. The GE 1.5-MW wind turbine was developed under such a program, for example, and the Clipper 2.5-MW turbine also was a product of a similar development program. Both of these turbines were developed as public-private partnerships in collaboration with a wind-industry partner to ensure that the resulting commercial product would be economically viable in the electricity marketplace. These turbines both currently are being installed in large numbers in the United States. In fact, the GE 1.5 has captured a majority share of the U.S. wind-turbine market and has garnered a significant share of the global market. This type of development process to produce a power generator for DHS applications could result in the creation of a commercial supplier of these power generators that could meet the remote generation needs of DHS and other agencies with similar needs, such as DOD.

\section{Long-Term Applications and Research}

In the longer term, it would be possible to develop more-complex high-performance systems for special applications that would have more demanding or unusual requirements for performance, cost, and reliability. Bottom-mounted ocean platforms, for example, that employ a multitude of sensors could be used to track ocean traffic both acoustically and by other means. Alternatively, an unmanned vehicle powered only by ocean waves could be developed to patrol a region of the ocean autonomously for long periods. Depending on the power needs and the application, hybrid power systems that make use of more than one renewable energy resource could be explored. For example, solar and wind generators could be used to augment the level of energy available.

There has been little recent development of hybrid power systems for special applications requiring high reliability and that run on locally available renewable energy resources. Perhaps now is the time to invest in the development of self-sustaining power systems that can operate unattended for long periods in harsh remote environments.

\subsection{Biofuels and Algae}

All algae are nonvascular plants (i.e., lacking a specialized nutrient-distribution system) and include macroalgae (seaweeds) and microalgae. Microalgae generally refer to all algae too small to be seen clearly without aid. They include the prokaryotic cyanobacteria and the eukaryotes green algae and diatoms, among other types. This report also includes aquatic plants such as duckweed in the general category of "algae," as they could be cultivated and harvested similarly.

Although algae perform oxygenic photosynthesis (i.e., split water to produce oxygen and fix carbon dioxide into biomass using sunlight), many also can use organic substrates (e.g., glucose, acetic acid) in the light or dark (mixotrophic growth and heterotrophic growth, respectively). This report discusses the multiple uses of algae, and proposes ideas that might be of interest to 
DHS. Most ideas described are longer-term research projects, with short-term research exceptions noted.

\section{Technology Overview-Biodiesel Production}

Although both microalgae and macroalgae for centuries have been used as foods, the potential of algae as feedstocks for fuel production is a relatively recent concept. In the 1950s, researchers began to evaluate algal biomass as an energy source using anaerobic digestion for producing methane. During the oil embargo in the 1970s, DOE began to fund the Aquatic Species Program which evaluated micro- and macroalgae along with aquatic plants and wetland emergents as feedstocks for energy production, eventually focusing on microalgae because their potential for high lipid production made them a potential feedstock for biodiesel production (lipid content as high as $60 \%$ of total biomass has been observed at NREL).

The lipids produced by microalgae primarily are composed of triacylglycerides (TAGs) which have a composition very similar to vegetable oils, although they can be enriched for polyunsaturated fatty acids such as omega-3 and omega- 6 fatty acids which have healthpromoting properties, but they actually are poor starting materials for fuels. More recently, vegetable oils and algae lipids have been converted to hydrocarbon biofuels by using conventional catalytic properties. The biofuels are used as substitutes for gasoline, diesel, jet fuel, and marine distillate. Solazyme, the company which produces algal lipids by a heterotrophic process (i.e., by growing algae in dark fermentors with sugar growth substrates), has contracts with the U.S. Navy to provide thousands of gallons of both jet fuel and marine distillate to assist in meeting the U.S. Navy goals for replacement of $50 \%$ of its fossil-fuel use (336 million gallons per year) by 2020.

\section{Biodiesel Co-Products}

Although it is the high lipid content of algae that have placed them in the spotlight for advanced biofuel production, that is only one part of the overall opportunity for energy generation. After lipids have been removed from the algal biomass, the remaining material contains approximately equal amounts of protein and carbohydrate. As such, this material remains a potential feedstock for anaerobic digestion to produce methane (Figure 17) - though the nitrogen-to-carbon ratio is a slightly high and could require supplementation with a low-nitrogen material such as municipal solid waste or forestry or agricultural residues. Wastewater treatment facilities often use algae ponds as part of tertiary wastewater cleanup and the biomass from that has been shown to be a suitable feedstock for anaerobic digestion. 


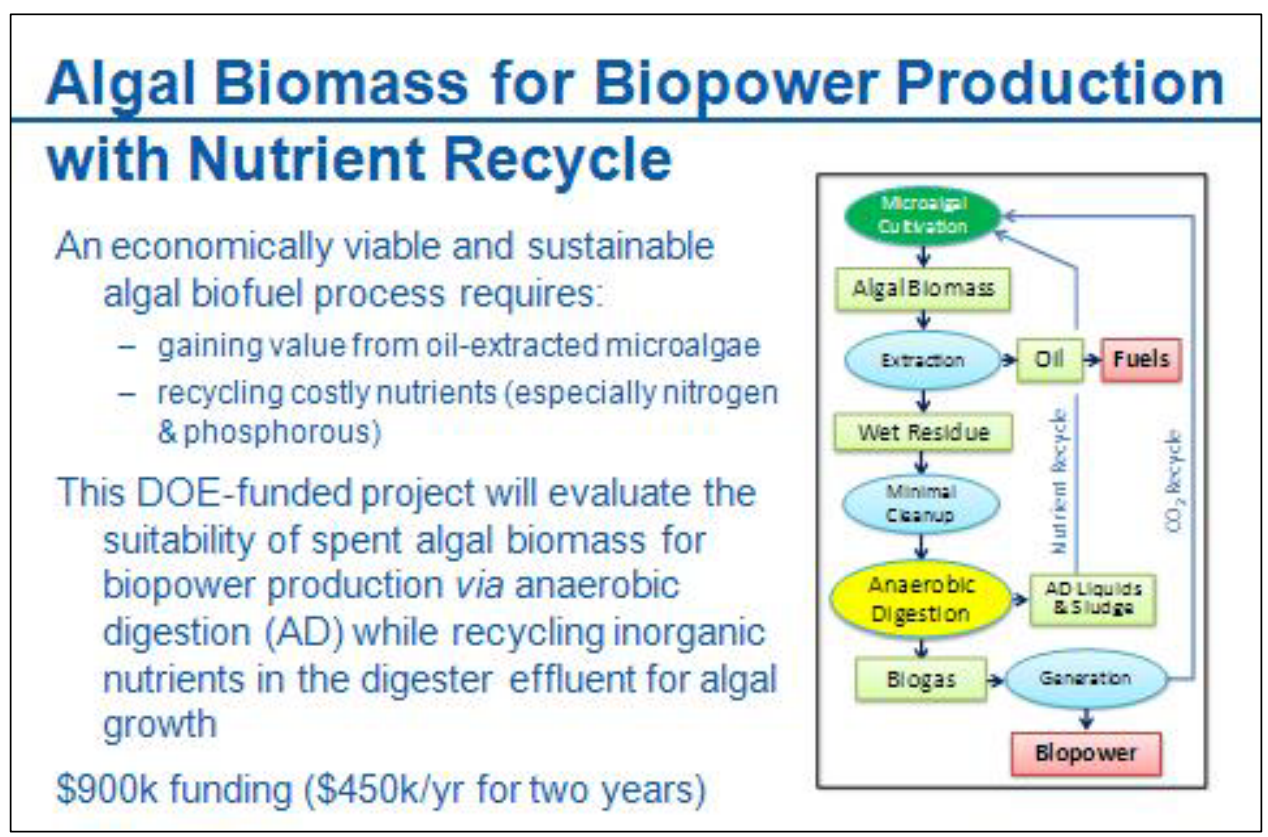

Figure 17. Biopower production using algal biomass. Illustration by NREL

The carbohydrate fraction of algal biomass also can be used as a feedstock for fermentation to ethanol or other advanced biofuels. Many algal strains can accumulate starch, thus providing a ready supply of glucose for fermentation. The oleaginous algae, however, do not make much starch, at least not under conditions of high lipid productivity. In these cases, once the lipids have been extracted the remaining carbohydrate mainly is in the form of cell-wall polymers. Just as plant cell walls (composed of cellulose, hemicellulose, and lignin) are more difficult to break down to monomeric sugars, algal cell walls have been shown to be resistant to degradation. Additionally, they can be composed of sugars rarely seen in plant cell walls, including glucosamine, uronic acids, and glycolipids. The decades of experience breaking down terrestrial plant biomass to monomeric sugars using both chemical and enzymatic treatments will not necessarily lead to rapid progress for the deconstruction of algal biomass, nor will the resulting sugars necessarily provide accessible substrates for fermentative organisms (Figure 18). 


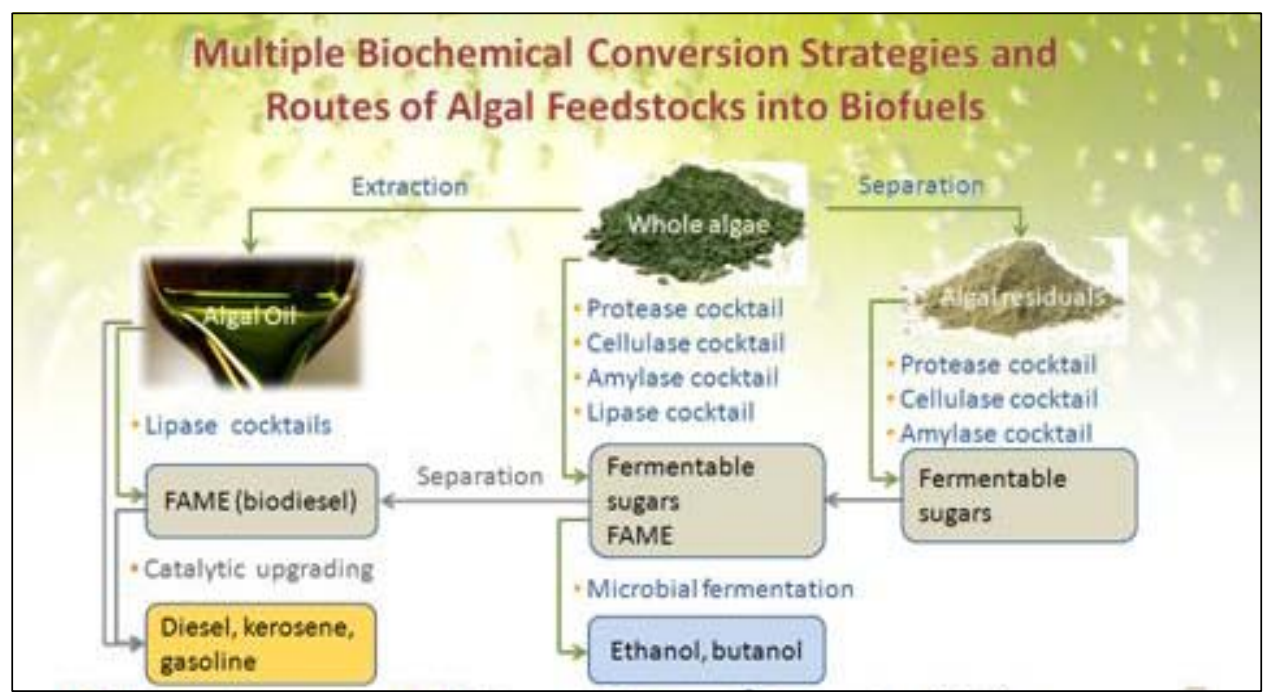

Figure 18. Biochemical strategies for converting algal feedstock into biofuels. Illustration from Sustainable Algal Biofuels Consortium

The most straightforward means of conversion of algal biomass to energy is through combustion in conventional engines, power plants, and boilers. Microalgal biomass has approximately the same energy content as coal, and proposals have been made to mix microalgae with diesel to reduce fossil-fuel use. Processes that involve spraying coal with microalgae slurries for use in power plants also have been described, but both of these approaches require significant dewatering of the algae biomass which reduces the energy returns and the value. The high nitrogen content of microalgal biomass relative to coal could result in high nitrogen-oxide (NOx) emissions or necessitate special scrubbing processes.

\section{Food and Feed Production}

Conversely, the high nitrogen content of algal biomass can make it a useful food source. As noted, microalgae and macroalgae have been used for foods for centuries. Algae strains such as Spirulina and Chlorella can be found in health food stores. These and other strains of algae have been used in aquaculture for fish and shellfish production. Algae proteins also are being considered as a replacement for animal or fish protein for animal and pet food, as the cost and availability of proteins becomes increasingly problematic. The same cost and availability pressure is causing human food producers to consider algae as a potential raw material.

In addition to the proteins in algae other components, such as carotenoids and omega- 3 fatty acids, also are in demand for nutraceuticals. These components often are produced in algae for use for food supplements. The omega-3 fatty acids found in abundance in fish is due to the accumulation in their tissues as algae are passed up the food chain. Algal biofuels are a highvolume, low-value product, therefore the production processes and raw materials to be used are by necessity low cost and low quality. There typically is a slight a disconnect in the discussions of high-value co-product (i.e., animal feed, human food) coupled with biofuel production.

\section{Water Remediation, Carbon Dioxide Capture, Oxygen Production,} Hydrogen Production, and Mineral Recovery

As noted, algae often are used for tertiary wastewater treatment, where they have the potential to remove inorganic nutrients such as nitrogen, phosphorous, and potassium from the water for 
incorporation into biomass. Algae have been shown to grow with earlier-stage wastewater, where they can metabolize the carbon compounds present. Under such conditions they grow mixotrophically; that is, with a mixture of carbon dioxide and organic carbon. Under these conditions, the algal growth has the added benefit of remediation of wastewater to advance its purification for disposal.

An economic value from algal growth can come from the capture of carbon dioxide (typically expected to come from fixed carbon-dioxide sources such as power plants and cement kilns), although the lack of federal policy regarding carbon dioxide emissions does not provide any immediate financial benefit. Part of the process of photosynthesis involves the splitting of water to yield oxygen. Under some conditions, the oxygen could be captured, providing some coproduct credit. Some algae also are able to reduce hydrogen ions in water to hydrogen gas, another potential product. Biological hydrogen production has been explored at NREL for a number of years, and although a production process can be complicated (oxygen inhibits hydrogen production, and producing oxygen and hydrogen simultaneously could lead to an explosion), much progress has been made regarding both the biology and the process options.

As noted, algae biomass can accumulate inorganic nutrients such as nitrogen, phosphorous, potassium, and sulfur, which can make the algae suitable for green fertilizer. This is true for both microalgae and macroalgae. It also is possible to recover the sludge from anaerobic digesters fed with algae biomass for recycling as a growth nutrient or for use as a fertilizer. Not only are algae capable of accumulating inorganic nutrients, they also have been shown to capture mercury and other heavy metals often present in flue gas from a coal-fired power plant or in the water used for cultivation. Although this can present a toxicity or environmental problem, it also can be considered a positive aspect of water remediation, and the ability to concentrate compounds present at low levels in the water phase might provide an opportunity for recovery of strategic materials.

Strategic materials could include precious or rare earth metals that could be present at concentrations in water too low to recover economically. In the future, a strategic material might be phosphorous, which rapidly is being depleted for fertilizer, solubilized, and lost to water runoff. Concentration and capture of these materials by algae could provide a competitive edge for the United States - which currently depends on foreign sources for procuring phosphorus.

\section{Department of Homeland Security Relevance: Biofuel and Algae Applications}

\section{Today's Opportunities and Tomorrow's Potential}

No off-the-shelf opportunities are currently available for algae. The only immediate opportunity for use of algal biomass is as a food supplement and nutraceutical source. Algae currently are grown for this purpose in large ponds or photobioreactors. If there is a use for these products in strategic areas for maritime and border security, production facilities could be established quickly, provided that the climate and necessary inputs (sunlight, carbon dioxide, nutrients, water) are available.
Wild Algae Harvest

A decommissioned USCG ship could be retrofitted for a pilot project to determine whether it would be possible to harvest wild algae. Macroalgae and aquatic plants should be the initial targets because they are more readily harvested than microalgae. The algae biomass could be converted to fuels and fertilizer at onshore anaerobic digesters. Alternatively the biomass could be used to generate fuel (methane) on board to power the ship's systems. An onboard anaerobic digester also could treat human waste for enhanced fuel production. 


\section{Wild Algae Harvest}

There might be water areas in which DHS operates that are rich in wild algae and other aquatic plants. Some water bodies are rich in nutrients from agricultural runoff and show periodic algae blooms. The decay of algae biomass is known to consume dissolved oxygen to levels unable to support animal survival, causing large areas of "dead zone." Wild algae harvesting thus could serve multiple functions, including waterway clearing to enhance patrol ship access; energy production from the algae biomass; nutrient removal for fertilizer production; and reducing dead zones to support fishery, recreation, and tourism.

Initially a decommissioned USCG ship could be retrofitted for a pilot project to determine whether it would be possible to harvest wild algae. Macroalgae and aquatic plants should be the initial targets because they are more readily harvested than microalgae. The algae biomass can be converted to fuels and fertilizer at onshore anaerobic digesters. Alternatively, the biomass can be used to generate fuel (methane) on board to power the ship's systems. An on-board anaerobic digester also could treat human waste for enhanced fuel production.

For large-scale nutrient removal from areas like the dead zone in the Gulf of Mexico around the mouth of the Mississippi River, macroalgae could be seeded and periodically harvested in a large-scale aquaculture. It's important to note that the dead zones are not formed by the algae themselves, but rather by the die-off that occurs after the algae bloom. The algal biomass becomes a nutrient for aerobic microorganisms which rapidly consume all of the available oxygen in the water, consequently killing fish and other aquatic animals. Deliberately harvesting the algae before the die-off would eliminate the dead zones and would allow for recovery of nutrients that otherwise would be lost at sea.

Research on the conversion of macroalgae to transportation fuels is ongoing. For example, the DOE ARPA-E program supports a Bio Architecture Laboratory and assists DuPont on macroalgae conversion to butanol (a gasoline replacement).

\section{Airport Algae Cultivation}

The requirements for large-scale cultivation of microalgae under photosynthetic conditions include land for ponds and photobioreactors (an acre of ponds can produce between 1,000 and 5,000 gallons of biodiesel or renewable jet fuel per year), water, carbon dioxide, inorganic nutrients, and sunlight. A project that might be of interest to DHS would be to establish algal-cultivation facilities in the unused land surrounding airports. NREL currently is in discussions with a group including a municipal airport, an electrical utility, a commercial algal-biofuels company, and a number of academic scientists to establish a demo facility at an airport. The facility would make use of carbon dioxide generated on site by incineration of municipal solid waste and would use brackish water from underground aquifers.

This sort of demonstration project could serve as a model for a number of similar facilities situated at USCG airports or at other municipal airports at which DHS operates. For airports

Airport Algae Cultivation
A project that might be of interest to
DHS would be to establish algal
cultivation facilities in the unused land
surrounding airports. NREL is currently
in discussions with a group including a
municipal airport, an electrical utility, a
commercial algal biofuels company, and
a number of academic scientists to
establish a demo facility at an airport.
The facility would make use of carbon
dioxide generated on site by incineration
of municipal solid waste and would use
brackish water from underground
aquifers.
Airport Algae Cultivation

A project that might be of interest to DHS would be to establish algal surrounding airports. NREL is currently in discussions with a group including a municipal airport, an electrical utility, a commercial algal biofuels company, and a number of academic scientists to establish a demo facility at an airport. The facility would make use of carbon of municipal solid waste and would use aquifers. 
located in remote locations, the algal products such as biofuels, methane, oxygen, and protein could help make the airport more self-sufficient and less dependent upon supplies brought in from other places. It also might be possible to determine additional uses of the cultivation facility. For example, the algal ponds could allow for improved instrumentation for navigation or emergency landings. The abundance of water used for cultivation also could be used for firefighting efforts.

The lowest capital-cost approach to production of algal biomass will make use of open-pond production systems (Davis et al. 2011). Much work is being done to reduce the cost for fabrication of photobioreactors to take advantage of the potential process superiority (e.g., greater biomass concentrations, enhanced carbon-dioxide transfer, reduced water evaporation) without incurring greater production costs. If costs are not an issue, and border or maritime security advantages are factored in, then material science research can be performed to fabricate photobioreactors from materials that have electropolymeric properties. This could enable the photobioreactor array to serve as sensors or large antennae for communications or security monitoring. Although it is unlikely that remote airports need be concerned with carbon-dioxide emissions, algal-cultivation facilities could be used to reduce GHG emissions from electrical generators.

\section{Border Algae Cultivation}

Algal cultivation facilities could be used to valorize underutilized land located near borders, especially the United States-Mexico border. The warm climate, availability of saline aquifers, and availability of sunlight throughout the desert southwest provide key ingredients for large-scale algae cultivation. As with remote airports, many areas around the United States-Mexico border are reliant on supplies that are brought in from remote locations. The algae ponds could provide energy and food products for more self-sufficient operation.

\section{Border Algae Cultivation}

Similarly, algal cultivation facilities could be used to valorize underutilized land located near borders, especially the U.S.-Mexico border. The warm climate, availability of saline aquifers, and availability of sunlight throughout the desert southwest provide key ingredients for largescale algae cultivation. As with remote airports, many areas around the U.S.-Mexico border are reliant on supplies that are brought in from remote locations. The algae ponds could provide energy and food products to allow for a more self-sufficient operation. Ponds or photobioreactors could be used to discourage or hinder border crossing and ponds could be fitted with sensors to monitor the sort of agitation that occurs when someone tries wading across. Additionally, algae culture and processing operation could transform some of the uninhabited border areas into inhabited areas, expanding the numbers and value of border guards and therefore enhancing border security.

Algae also could be grown next to other strategic sites where a significant quantity of carbon dioxide is generated, for example, on a DHS remote installation that uses a power generator continuously. The algae biomass then can be digested anaerobically for biogas production. This could be a short-term research project. Initial test and demonstration could involve cultivation of duckweed with carbon-dioxide feeding, because duckweed is easy to harvest. 
Cultivation in Bay and Tidal Zones

Another short-term research project could be to grow algae in waters sheltered from waves. Macroalgae culture and harvesting techniques are well established in Asia, with China being the largest macroalgae producer in the world. Macroalgae can be used for food, as industrial feedstock for extraction of high-value chemicals, and for fuel production. For DHS remote installations, food and fuel from macroalgae culturing could enhance self-sufficiency. Initial fuel production could be via anaerobic digester.
Macroalgae Cultivation

Macroalgae can be grown in waters sheltered from waves. Macroalgae can be used for food, as industrial feedstock for extraction of high value chemicals, and for fuel production. For DHS remote installations, food and fuel from macroalgae culturing could enhance self-sufficiency. Initial fuel production could be via anaerobic digester.

Microalgae could be grown in tidal zone using either seawater or freshwater entering the sea; tidal zones are underutilized surface areas. A challenge for algae cultivation in the area is that the facility must be built to withstand periodic flooding by seawater.

\subsection{Energy Efficiency-Opportunities for Systemic Optimization of Existing and Future Systems}

In general, energy efficiency opportunities fall into two categories.

- New materials or breakthroughs which create new classes of products or categories of products that operate more energy efficiently than current products or system components.

- Systemic rightsizing of components or subassemblies which are a part of a system. These components originally were used to reduce the first-cost of the system at the expense of higher operational energy consumption. Power supplies are notorious for being designed for reduced price and not for low power consumption, and are contained in almost every electronic device. Desktop computer power supplies, for example, use half of their power just for the fan used to remove waste heat from the power supply.

Advantages to optimizing existing systems include reducing the need to refuel devices, as well as reducing the size and potentially the first cost of the unit which supplies the source-power for the unit. Disadvantages to optimizing existing systems include the need to design custom units or retrofit off-the-shelf units, and potentially voiding their warranties. This can be avoided by developing solutions in cooperation with the equipment manufacturers. There also is the potential for higher first costs.

\section{Department of Homeland Security Relevance: Optimize Existing Systems}

Improving the efficiency of equipment can lengthen the operating time between recharging or refueling of covert equipment, which could lengthen the lifetime of the equipment and reduce or help eliminate the amount of time DHS personnel are required to be in hazardous circumstances under which refueling in remote sites often occurs. For example, improving the efficiency of the power supplies used in mountaintop radio broadcasting equipment would reduce their energy consumption and would therefore also reduce the need to sling propane tanks down from helicopters to the mountaintop to refuel storage tanks located there. This benefit therefore potentially could reduce the manpower needed to refuel devices. 


\section{Today's Opportunities}

\section{Improving the Efficiency of Electronic Devices}

Virtually all of the existing electronic devices used by DHS can be analyzed to determine how efficiently they utilize power and also how they potentially can be retrofitted. This eventually could lead manufacturers to incorporate efficiency improvements identified by NREL into nextgeneration products.

\section{Developing Rapidly Deployable, Self-Sufficient Arctic Housing Units}

There is a need for the USCG to expand their operations into the upper arctic regions of Alaska. This was confirmed in a recent speech on June 20, 2011, by the Coast Guard Commandant, in which he described the huge increase in commercial oil and shipping activity in the arctic areas since the warming of the arctic passageways. He described the USCG's need to rapidly deploy bases to cover these areas in case of oil spills or other significant incidents. In addition, cruise lines are beginning to venture as far north as the Bearing Strait. All of these ships are unprotected and vulnerable to terrorism, piracy, and environmental disaster. If something were to happen, the distance from current USCG facilities to these newly opening areas is equivalent to flying halfway across the lower continental United States.

This situation has caused the USCG to begin planning for several small FOBs which, for deployment speed, may consist of a rented hangar at an existing airport. By deploying containerized ultra-efficient, self-contained, $100 \%$ renewably powered portable housing units, the USCG will be able to rapidly roll out these FOBs without the usual 5-year construction process by just placing several of these units at a rented hangar. In addition, as new issues emerge, these units could be rapidly moved to new locations to cover new threats without the need to deal with the complications of expanding utilities.

\section{Reducing the Frictional Drag of Ships Utilizing Low Drag Coatings}

There is a new generation of Low-Drag Ship Hull Coatings which can reduce the frictional drag on ship's hulls. These new coating, based on biologically and chemically inert Teflon-type compounds, are a new generation of coatings which not only prevent the build-up of biological organisms, but also reduce the frictional drag of the ship hull surfaces. These compounds improve on past coatings which were primarily designed to kill biological organisms and thus prevent the build-up of biologically induced surface roughness, which increases frictional losses for ships. The new coatings not only save energy by reducing frictional drag, they also reduce the frequency with which ships need to be dry-docked for hull cleaning, which is a very expensive and time consuming process.

\section{Tomorrow's Potential}

We anticipate that additional opportunities will emerge as NREL staff dialog with and visit additional DHS sites.

\section{Long-Term Applications and Research}

\section{Reducing the Frictional Drag on Ships Utilizing Micro-Bubble Technology}

Emerging research indicates that ships may be able to be retrofitted to utilize micro bubbles injected at the bottom of the hull of ships to further reduce the frictional drag on these ships. Based on other friction reduction technologies' effects, this type of system should also increase 
distance range and increase the top speed of existing ships, and possibly allow the reduction in engine size of future generations of ships.

It may be possible to combine this micro-bubble technology with low frictional ship hull coatings and utilize the carbon dioxide from the exhaust of ship engines to provide the source gas for this effect. In addition, the resulting carbon dioxide-enriched water after it has provided its friction reducing effect would further speed the growth of algae and the scavenging of lost nutrients in nutrient-overburdened areas such as the dead zone in the Gulf of Mexico at the mouth of the Mississippi. Even if the system could not be utilized in an on-board algae harvesting system, it may be possible that introducing ship engine carbon dioxide into sea waters (depending on the waters) could provide some form of partial carbon dioxide sequestration or short-cycling, thus reducing the Coast Guard's effect on climate change due to fuel consumption. 


\section{Conclusions}

Renewable energy technologies present a number of near-term applications and longer-term research opportunities that can enhance DHS component operations. These technologies-PV, wind turbines, batteries, fuel cells, biofuels, MHK, wireless energy transfer, and energy efficiency - exist now or can be developed, and can enable the mission to be more stealthy, secure, safe, effective, or efficient. The technologies and opportunities outlined in this report can form a solid foundation for BMD's renewable energy research portfolio.

Next steps in identifying the most appropriate technologies for near-term deployment include further data collection and analysis of on-the-ground operations, prioritization of existing or anticipated needs by equipment users and other stakeholders, and identification of solutions. Research opportunities exist to pilot solutions that have previously been identified during site visits, such as stadium lighting systems that incorporate PV panels, LED lighting, and smart controls. Additional, multi-year research strategies can be devised to create application-specific solutions for existing and anticipated operational needs. 


\section{References}

American Wind Energy Association, AWEA. "Industry Statistics."

www.awea.org/learnabout/industry_stats/index.cfm. Accessed June 23, 2011.

"AWEA Small Wind Turbine Global Market Study Year Ending 2009." (2009).

www.awea.org/learnabout/smallwind/upload/2010_AWEA_Small_Wind_Turbine_Global_Mark et_Study.pdf. Published by the American Wind Energy Association. p. 3.

Bedard (2006). Bedard, R. "Overview: EPRI Ocean Energy Program." Presented to the Duke University Global Change Center, (April 2006). Available at the EPRI Ocean Energy Website: http://oceanenergy.epri.com/attachments/ocean/briefing/Duke_Sep_14.pdf.

Bedard, R.; Previsic, M.; Hagerman, G.; Polagye, B.; Musial W.; Klure J.; von Jouanne, A.; Mathur U.; Collar, C.; Hopper, C.; Amsden, S. (2007, March). "North American Ocean Energy Status-March 2007." Presented at The $7^{\text {th }}$ European Wave and Tidal Energy Conference, Porto, Portugal. http://oceanenergy.epri.com/attachments/ocean/reports/7th_EWTEC_Paper_FINAL_071707.pdf.

Bedard, R. (2008, December). Prioritized Research, Development, Deployment and Demonstration (RDD\&D) Needs: Marine and Other Hydrokinetic Renewable Energy. Final Report. Palo Alto, CA: Electric Power Research Institute. http://oceanenergy.epri.com/ attachments/ocean/reports/Final_MHK_Prioritized_RDD_Needs_Report_123108.pdf.

Boehlert, G.; McMurray, G.; Tortorici, K. (2007, October). Ecological Effects of Wave Energy Development in the Pacific Northwest. NOAA Technical Memorandum NMFS-F/SPO-92. Workshop, October 11-12, 2007. Washington, DC: U.S. Department of Commerce, National Oceanic and Atmospheric Administration. http://hmsc.oregonstate.edu/waveenergy/

Callaghan, J. and Boud, R. (2006). "Future Marine Energy, Results of the Marine Energy Challenge: Cost Competiveness and Growth of Wave and Tidal Stream Energy." The Carbon Trust, (2006). Available at www.thecarbontrust.co.uk.

DOE. (2011). "Marine and Hydrokinetic Technology Database." U.S. Department of Energy Wind and Water Power Program Website available at: www.eere.energy.gov/windandhydro/about.html.

EquiMar. (n.d.). "EquiMar - working to harness marine energy." www.equimar.org/2010/05/new-welcome.html.

Falcao (2010). Falcao, A. "Wave Energy utilization: A Review of the Technologies," Renewable and Sustainable Energy Reviews, 14 (2010), pp. 899-918.

Gill, A. (2005). "Offshore renewable energy: ecological implications of generating electricity in costal zones.” J. Appl. Ecol. 42, pp 605-615. 
Grecian, W.; Inger, R.; Attrill, M.; Bearhop, S.; Godley, B.; Witt, M., and Votier, S. (2010).

"Potential impacts of wave-powered marine renewable energy installations on marine birds." Ibis (2010), 152 pp. 583-697.

Handbook of Batteries, Third Edition. (Linden and Reddy 2002).

Hanson, H.; Skemp, S.; Alsenas, G.; Coley, E. (2010). "Power from the Florida Current: A New Perspective on an Old Vision." Bulletin of the American Meteorological Society; pp. 861-866.

Hau, E. (2000). Wind Turbines: Fundamentals, Technologies, Application, Economics. Springer, Germany.

International Energy Agency, Ocean Energy Systems Implementing Agreement. IEA-OES. (2010). IEA-OES Annual Report 2010. www.iea-oceans.org/ fich/6/2010 Annual Report.pdf.

IEA - OES (n.d.) "Annex IV: Assessment of Environmental Effects and Monitoring Efforts for Ocean Wave, Tidal, and Current Energy Systems" Information available at http://www.ieaoceans.org/tasks.asp?id=4.

IEA - OES (2010). "Annual Report 1020 for the Implementing Agreement of Ocean Energy Systems.” Available at http://www.iea-oceans.org/index.asp.

Inger, R.; Atrill, M. Bearhop, S.; Broederick, A.; Grecian, W.; Hodgson, D.; Mills, C.; Sheehan, E.; Votier, S.; Witt, M.; Godley, B. (2009). "Marine renewable energy: potential benefits to biodiversity? An urgent call for research.” J. Appl. Ecol. 46, pp 1145-1153.

Jennings, D. M.; Jones, K.; Silverberg, K.; Wais, E.; Maloney, S.; Tuohy, R.(August 2010). S\&T Borders and Maritime Security Division Strategic Planning: Final Report. Publication number RP10-34-02. Arlington, VA: Prepared by Homeland Security Studies and Analysis Institute for U.S. Department of Homeland Security, Science and Technology Directorate, Borders and Maritime Security Division.

Khan and Bhuyan (2009). Khan, J. and Bhuyan, G. "Ocean Energy: Global Technology Development Status," Report prepared by Powertech Labs for the IEA-OES, March 2009. www.iea-oceans.org/_fich/6/ANNEX_1_Doc_T0104.pdf.

Molly, J.-P. (1978). Windenergie in Theorie und Praxis, Grundlagen und Einsatz. German Edition.

Musial, W. and Ram, B. "Large-Scale Offshore Wind Power in the United States: Assessment of Opportunities and Barriers." NREL Report No. TP-500-40745, (2010). Available from http://www.nrel.gov/docs/fy10osti/40745.pdf. Accessed November 2010

National Renewable Energy Laboratory, NREL. (March 2010). "CDP\#6: Fuel Economy." www.nrel.gov/hydrogen/docs/cdp/cdp_6.ppt.

Polagye, B.; Copping, A.; Kirkendall, K.; Boehlert, G.; Walker, S.; Wainstein, M.; and Van Cleve, B. (2010). Environmental Effects of Tidal Energy Development: A Scientific Workshop. 
Workshop Briefing Paper for the Workshop held March 22-24 at the University of Washington, Seattle, Washington. http://depts.washington.edu/nnmrec/workshop/index.html.

Thresher, R. (2010) “The United States Marine Hydrokinetic Renewable Energy Technology Roadmap." Draft roadmap developed by the National Renewable Energy Laboratory. Available online at http://www.oceanrenewable.com/press-room/.

Windustry. Wind Basics, "How much do wind turbines cost?" www.windustry.org/how-muchdo-wind-turbines-cost. Accessed June 6, 2011.

Wiser, R. and Bolinger, M. (2010). "2009 Wind Technologies Market Report." 88 pp.; NREL Report No. TP-6A2-48666; DOE/GO-102010-3107, (2010). Available from http://www.nrel.gov/publications/. 


\section{Appendix A. Department of Homeland Security Workshops and Site Visits}

March 19, 2010 (Washington, DC): Introductory Workshop

Attendees

- NREL: Andrea Watson

- SBInet
- Allen Gamble, Executive Director
- Merv Leavitt, SBI technical director
- Sarah Schroerluke, Northern Border Director
- Jim Rierdon, Program Manager SBInet
○ Brian Willoughby

June 21, 2010 (Washington, DC): Data Gathering and Application Prioritization Workshop (CBP/NREL)

Agenda: Monday, June 21, 2010

12:30-1:00 pm Introductions, Workshop Overview and General Background

- Around the room introductions

1:00 - 1:15 pm Overview (NREL)

- Brief overview of NREL and team capabilities, project scope, and project timeline

1:15 - 1:30 pm Overview (CBP)

1:30 - 2:30 pm Energy Needs Brainstorm

- Outline CBP energy needs

○ Energy-using equipment

- Locations

○ Grid connected vs. off-grid

○ Quantity

- Priorities and vulnerabilities
- Noise
○ Visibility
- Cost
- Other

2:30-2:45 pm Break

2:45 - 3:30 pm Energy Needs Brainstorm (continued)

- Future operations and energy needs

- Partnerships
- DOD
- Manufacturers
o Other 
3:30 - 4:00 pm

Data Collection Methodology

- Sensitive data

- Site visit(s)

- O\&M contacts

4:00-4:30 pm Next steps

\section{Attendees}

\begin{tabular}{|c|c|c|}
\hline NAME & ORGNWIZATION \& POSIIION & EMAll. \\
\hline ALICEN KANDT & NREL, SR. ENGINEER & ALICEN.KANOT CNREL.GOV \\
\hline SCOH HUFFORAN & NREL, SR, ENGINEER & SCOtt.1tUFFMAN@NREL.GOV \\
\hline Tom Kmin & SBI-OIO $\quad T h$ & ombsakinip@Assraitres.dhsiqul \\
\hline STEVE CARHART & - SBI net & tepheu.Carhartodks.gor \\
\hline & $S B E$ & irv.Leavitteaths. gav \\
\hline BCosccouchis & SBF SUPPONT & In@willan.rom \\
\hline LEO MORRIS & $S B I-O I D$ & .MORRIS@DAtS.6OV \\
\hline Fracy Dillard & SHT'SETA Support & 1.211sen-dillard ansigov. \\
\hline Kuret Guth & SBlnet & tis.Guth@dhs.gov \\
\hline RACPH SICKINGER & SBInet & kinger@willcor.com \\
\hline TIFFANY Burton & Border Patrol & any. burton edhs.gor \\
\hline
\end{tabular}

\section{June 21, 2010 (Washington, DC): Data Gathering and Application Prioritization Workshop (CBP/NREL)}

CBP personnel next presented an overview of the types of equipment typically used to accomplish their mission and the types of conditions under which the equipment is typically used. There were approximately 25 different pieces of equipment identified by generic name or purpose as well as manufacturer. 


\begin{tabular}{|l|l|}
\hline Mission Equipment & Manufacturer \\
\hline MSS/MSC & Telephonics Corp. \\
\hline Re-deployable radar & Telephonics/IAI \\
\hline Re-deployable camera & Flur, Axsys, more \\
\hline Game camera & varied \\
\hline Microwave relay tower & Boeing Corp. \\
\hline SBInet radar camera tower & Boeing Corp. \\
\hline Clandestine comms & L3, Motorola, more \\
\hline Remote deployment Base & TBD \\
\hline RVSS tower & Boeing Corp. \\
\hline LETC & WIN-Radio, L3 \\
\hline TRIPwire & TBD \\
\hline UGS & Varied \\
\hline SAT Ku band receiver ... Huges & Huges \\
\hline LOS downlink (BMS) & BMS \\
\hline 802.11/16 & varied \\
\hline Lighting & varied \\
\hline 5KW generator equivalent & varied \\
\hline &
\end{tabular}

July 22-23, 2010 (Bellingham, WA): Northwest Border Low-Flier Workshop The purpose of this workshop was to bring together technologists with the major stakeholders within the Coast Guard who are responsible for apprehending low flying aircraft bringing contraband into the US primarily over the Northwest border with Canada near Seattle and Spokane. The goal of the meeting was to decide the best use of funding for a short term technology solution and brainstorm and write an RFP for a longer term solution which might be procured. NREL Attendees: Scott Huffman, and John Leahey

\section{Agenda}

July 22, 2010-Chrysalis Inn Conference Center

0830-0845 Background and Introductions

0845-0930 Meeting Purpose and Scope

0930-1050 Threat Assessment and Current CONOPS

- 0930-1000 Havre Sector/Air Branch

- 1000-1030 Spokane Sector/Air Branch

- 1030-1050 Blaine Sector/Bellingham Air Branch

1050-1200 Potential Technologies and Other Agency Briefs

1200-1330 Lunch

1300-1700 System CONOPS

July 23, 2010-Washington State Patrol Conference Room 0830-1020 DOTMLPF Analysis 
1020-1030 Break

1030-1200 Capture Operational Requirements

1200- 1300 Lunch

1300-1530 Wrap Up and Way Ahead

Attendees
\begin{tabular}{|l|l|l|l|}
\hline Name & Organization & Phone Number & Email Address \\
\hline Harley McCray & CBP/SBI & 5714687496 & harley.l.mccray@cbp.dhs.gov \\
\hline John Leahey & NREL & 3032754241 & john.leahey@nrel.gov \\
\hline Scott Huffman & NREL & 3032754384 & scott.huffman@nrel.gov \\
\hline Bob Dorsey & DHS S\&T & 7038777159 & dorseyr@msd.nro.mil \\
\hline Swami lyer & USAF Test Pilot School & 6612278882 & swami.iyer@edwards.af.mil \\
\hline Sean Monroe & CBP/OBP & 3603329213 & sean.monroe@dhs.gov \\
\hline Terry Jenner & CBP/AMO(MT) & 4067504675 & terry.jenner@dhs.gov \\
\hline Todd Liebrand & CBP/Border Patrol & 4069452300 & todd.liebrand@dhs.gov \\
\hline Chuck Lair & CBP/AMOC & 9515709676 & chuck.lair@dhs.gov \\
\hline Lance R. Lyons & CBO/OBP/SPW & 5093532397 & lance.lyons@dhs.gov \\
\hline Todd Birdsong & CBO/OBP/SPW & 5093532747 & todd.I.birdsong@dhs.gov \\
\hline Mike Amato & CBP/SBI & 5714687066 & michael.amato@cbp.dhs.gov \\
\hline Andrea Coffey & CBP/SFO & 3603322695 & andrea.coffey@dhs.gov \\
\hline Mike Bumberger & SBP/AMOC & 9516560965 & michael.bumberger@dhs.gov \\
\hline Merv Levitt & CBP/SBI & 5714687568 & merv.levitt@dhs.gov \\
\hline John Abe & NRO/GED & 4089787520 & johnabe@rightmagic.com \\
\hline Raul Rios & NRO & 2066972225 & raul.a.rios@us.army.mil \\
\hline Debbie Engels & CBP/OFO & 3603324656 & deborah.engels@dhs.gov \\
\hline Cesar Moreno & CBP/OBP/SIU/AMO & 3609270259 & cesar.moreno@cbp.dhs.gov \\
\hline Darrell Feller & CBP/OAM & 2022555944 & darrell.feller@dhs.gov \\
\hline Christopher Rosen & CBP/OAM & 3604108359 & christopher.rosen@dhs.gov \\
\hline Luis Bencosmo & CBP/OAM & 5866128391 & luis.bencosmo@dhs.gov \\
\hline Keith Powell & CBP/OAM & 3607345939 & keith.powell@dhs.gov \\
\hline Rob Smith & CBP/OAM & 5095359416 & rob.smith@dhs.gov \\
\hline Maria Ireland & CBP/OAM & 5714687286 & maria.g.ireland@cbp.dhs.gov \\
\hline Chris Higgins & CBP/SBI & 7034016929 & higgins_chris@bah.com \\
\hline Leo Morris & CBP/SBI & 5714687569 & leo.a.morris@cbp.dhs.gov \\
\hline
\end{tabular}

\section{October 26-29, 2010 (EI Paso, TX): El Paso Sector}

The purpose of this meeting was to kick off the site-visit of the NREL staff members Scott Huffman, Alicen Kandt, and Travis Simpkins to the El Paso Sector and introduce them to the various sites and challenges faced by CBP personnel in the region. The rest of the week was spent visiting the CBP sites in the El Paso Sector to see sites firsthand and interview field personnel about technology needs and challenges that might be able to be solved with RE and EE.

\section{Agenda}

October 25, 2010-Travel Day

October 26, 2010-Day 1

$0900 \quad$ Kick-Off Meeting at El Paso Border Patrol Sector Headquarters 
1100 Ysleta, TX Border Patrol Station (Communications Tower/Fueling Area)

$1200 \quad$ Lunch

1300 Ysleta, TX Border Patrol Permanent Checkpoint

1430 El Paso, TX Border Patrol Station (RVSS Sites) (Maybe PDT)

- Levee Stadium Lighting (International Boundary at YST and/or EPS)

- Portable Light Plants (Levee/International Boundary at YST/EPS)

- Skybox Towers (International Boundary at YST and/or EPS)

October 27, 2010-Day 2

$0800 \quad$ Bridge of The Americas OFO Facility (Port of Entry Cargo Operations)

1000 Santa Teresa, New Mexico Border Patrol Station

- Mobile Surveillance System, Recon III, FLIR

$1200 \quad$ Lunch

1300 Border Patrol Special Operations Division (Mobile Command Center)

1430 Border Patrol Emergency Planning Office (Generators, Batteries)

October 28, 2010-Day 3

0900 Deming, New Mexico Border Patrol Station

1000 Deming, New Mexico Border Patrol Tactical Checkpoint (Highway 11)

$1200 \quad$ Lunch

1300 Border Patrol Forward Operating Base (Deming, NM Border Patrol Station)

1400 Boeing SBInet Tower in Playas, NM (Deming, NM Border Patrol Station)

October 29, 2010-Day 4

$0800 \quad$ Catch-Up Day

- Question and Answer (Data Collection, Action Items)

$1200 \quad$ Lunch

$1400 \quad$ Close-Out Meeting at El Paso Sector Headquarters

October 30, 2010-Travel Day

*ITEMS TO DISCUSS: Fuel \& Power Issues, Personnel Interviews, Battery Issues, Fuel Procedure/Policy, Fuel Usage Data, Packable Power 


\section{Attendees}

MEETINGI

CONFERENCE

DATE

\begin{tabular}{|c|c|c|}
\hline NAME & EMAIL & PHONE \\
\hline KENNY WARE & 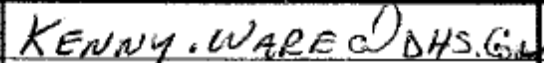 & $315-5267324$ \\
\hline Tohn Rivera $(C B P)$ & john rivera@als. sou & $915 \cdot 633-7300$ \\
\hline SCOHI HUEFAN (NREL) & SCOH.HUFAMAN@NREL.sOI & $303-275-4384$ \\
\hline Tranis Simpkins (NREL) & trovis simpkins enpel.ger & $303-274-4242$ \\
\hline GLICEN KBNOT (NRP) & ALICEN.KANOT@ NRE, GON & 303.384 .7518 \\
\hline & robert, boatrisht e Dus.GeV & $915-834-8367$ \\
\hline John Contreras & john contreras edus gov & 9154780118 \\
\hline Iman R. Ramirez & IVan ramirez $B$ dhs $90 \mathrm{~V}$ & $915-834-8623$ \\
\hline Parmen Bueno & carmenbueno@dhs.gov & $915 \cdot 854.8882$ \\
\hline \multicolumn{3}{|l|}{$I$} \\
\hline Int Hitehcode & joshuminitchoves?DHs.6ov & 015.854 .8363 \\
\hline Jumes EstrapA & 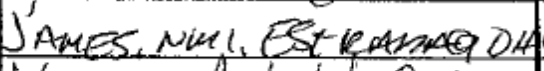 & $5.600 \quad 91 f=854-$ \\
\hline Veronicatrolnuleta & Veronica.Archuleta@gsa.9 & $v(915) 491-500^{\circ}$ \\
\hline Hipolito Carillo & Hipdito. Car: lloged dhs gou & $915-861-8107$ \\
\hline & & \\
\hline
\end{tabular}

\section{April 5-9, 2011 (Juneau, AK): AK USCG Operations}

The purpose of this site visit was to meet with USCG personnel regarding mission challenges they face related to border security and ways in which RE and EE could be used to solve these challenges.

\section{Agenda}

\begin{tabular}{|c|c|c|}
\hline Date & Scott Huffman & Alicen Kandt \\
\hline Monday, April 4 & Travel to Juneau, AK & \\
\hline Tuesday, April 5 & $\begin{array}{l}\text { Meet with Kodiak } \\
\text { biomass project } \\
\text { stakeholders }\end{array}$ & Travel to Juneau, AK \\
\hline Wednesday, April 6 & $\begin{array}{l}\text { Meet with USCG R21 } \\
\text { at Mayflower Island to } \\
\text { discuss wind and fuel } \\
\text { cell opportunities }\end{array}$ & $\begin{array}{l}\text { Meet with USCG R21 } \\
\text { at Mayflower Island to } \\
\text { discuss wind and fuel } \\
\text { cell opportunities }\end{array}$ \\
\hline Thursday, April 7 & TBD: Site visits? & TBD: Site visits? \\
\hline Friday, April 8 & $\begin{array}{l}\text { TBD: Site visits? } \\
\text { Travel home }\end{array}$ & $\begin{array}{l}\text { TBD: Site visits? } \\
\text { Travel home }\end{array}$ \\
\hline
\end{tabular}




\section{Appendix B. Wind}

\section{Windside}

The table below lists the expected power output at various wind speeds for several models of the Windside turbines. Without an effective wind resource history, it is recommended to consider either the WS-12 or WS-30 Model (shown in italics). Though not shown explicitly in this table, "Model A" turbines are designed for the most extreme winds - $60 \mathrm{~m} / \mathrm{s}(134 \mathrm{mph})$ - are the recommended version of these turbines to consider for the communication sites.

Table 5. Power Output at Various Wind Speeds for Windside Turbine Models

\begin{tabular}{cccccccc}
\hline & Wind & $\begin{array}{c}\text { Model } \\
\text { WS-0.15 } \\
\text { Power (W) }\end{array}$ & $\begin{array}{c}\text { Model } \\
\text { WS-0.30B } \\
\text { Power (W) }\end{array}$ & $\begin{array}{c}\text { Model } \\
\text { WS-2 } \\
\text { Power (W) }\end{array}$ & $\begin{array}{c}\text { Model } \\
\text { WS-4 } \\
\text { Power (W) }\end{array}$ & $\begin{array}{c}\text { Model } \\
\text { WS-12 } \\
\text { Power (W) }\end{array}$ & $\begin{array}{c}\text { Model } \\
\text { WS-30 } \\
\text { Power (W) }\end{array}$ \\
$3 \mathrm{~m} / \mathrm{s}$ & $7 \mathrm{mph}$ & 1 & 2 & 10 & 20 & 60 & 150 \\
$4 \mathrm{~m} / \mathrm{s}$ & $9 \mathrm{mph}$ & 2 & 4 & 20 & 40 & 120 & 300 \\
$5 \mathrm{~m} / \mathrm{s}$ & $11 \mathrm{mph}$ & 3 & 7 & 35 & 70 & 211 & 527 \\
$6 \mathrm{~m} / \mathrm{s}$ & $13 \mathrm{mph}$ & 5 & 10 & 50 & 100 & 300 & 750 \\
$7 \mathrm{~m} / \mathrm{s}$ & $16 \mathrm{mph}$ & 7 & 15 & 75 & 150 & 450 & 1,125 \\
$8 \mathrm{~m} / \mathrm{s}$ & $18 \mathrm{mph}$ & 10 & 21 & 105 & 210 & 630 & 1,575 \\
$9 \mathrm{~m} / \mathrm{s}$ & $20 \mathrm{mph}$ & 15 & 30 & 150 & 300 & 900 & 2,250 \\
$10 \mathrm{~m} / \mathrm{s}$ & $22 \mathrm{mph}$ & 20 & 40 & 200 & 400 & 1,200 & 3,000 \\
\hline
\end{tabular}

Table 6. Power Curves for Proven 11 Wind Turbine

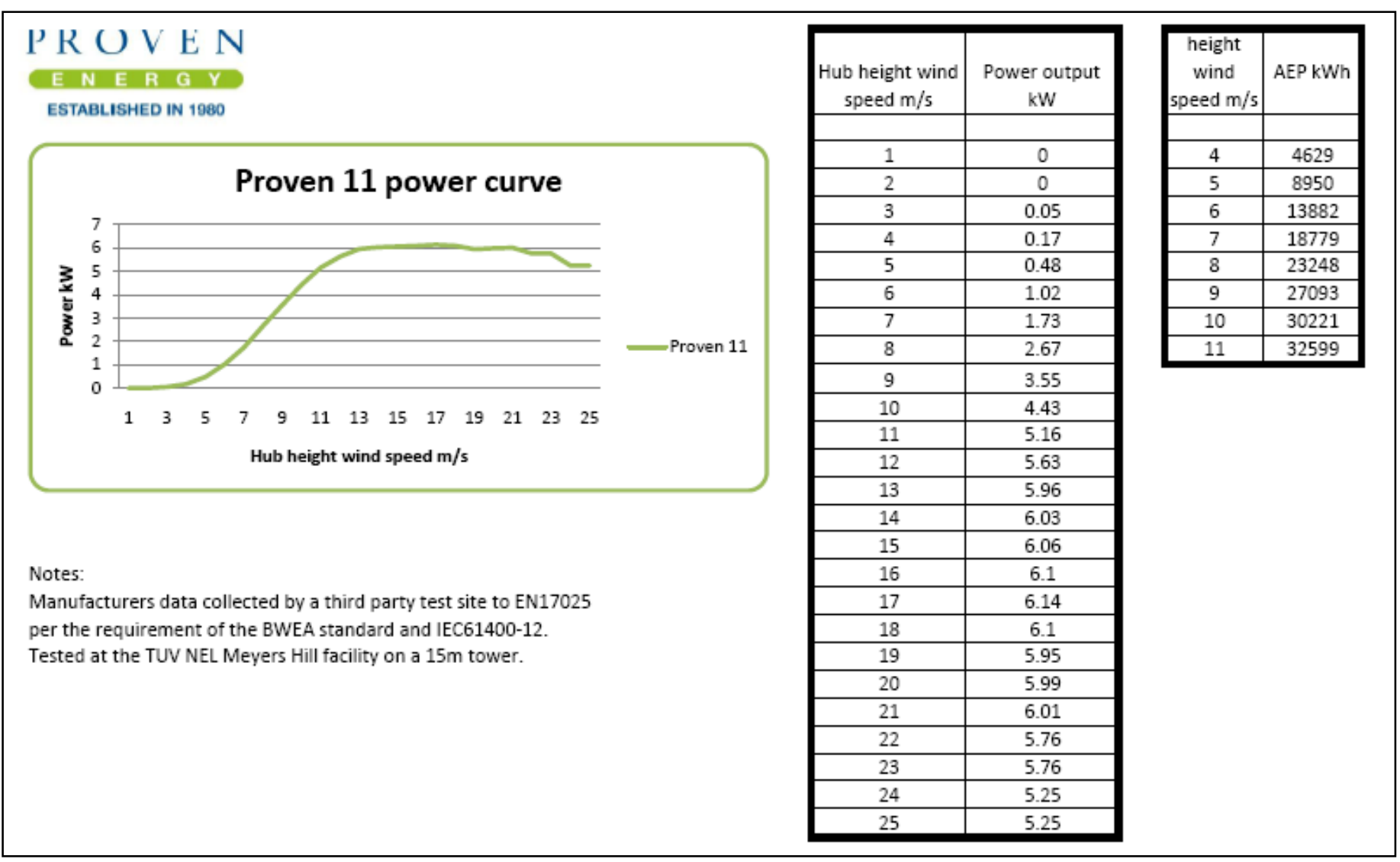




\section{Appendix C. Fuel Cells}

Evaluation of technologies for topic areas:

In the following tables, we display the concensus of four NREL staff in regards to the applicability of fuel cell technologies to individual DHS applications. The NREL staff who participated in the analysis each have industrial background in fuel cell design before joining NREL. We incorporated expertise from stationary prime-power fuel cells, backup power fuel cells, and portable direct methanol fuel cells. We used a decision matrix for this analysis. Each staff member was provided a table. The tables were used to record the wellness of technological fit between each DHS energy application and each fuel cell type. Additionally, we solicited our experts to provide a list of potential system suppliers and developers. Suppliers were provided for each category of fuel cell application. Once all tables were complete, we aggregated the tables. Below we display the results of our findings. High scores reflect better fit between fuel cell technologies and DHS applications. For example, a score of 9 means that all experts agree that this can be a very good technological fit, while a score of 1 means the fit is marginal. Areas where no score is assigned, we believe there isn't a good fit at all.

\section{BACK-UP APPLICATIONS}

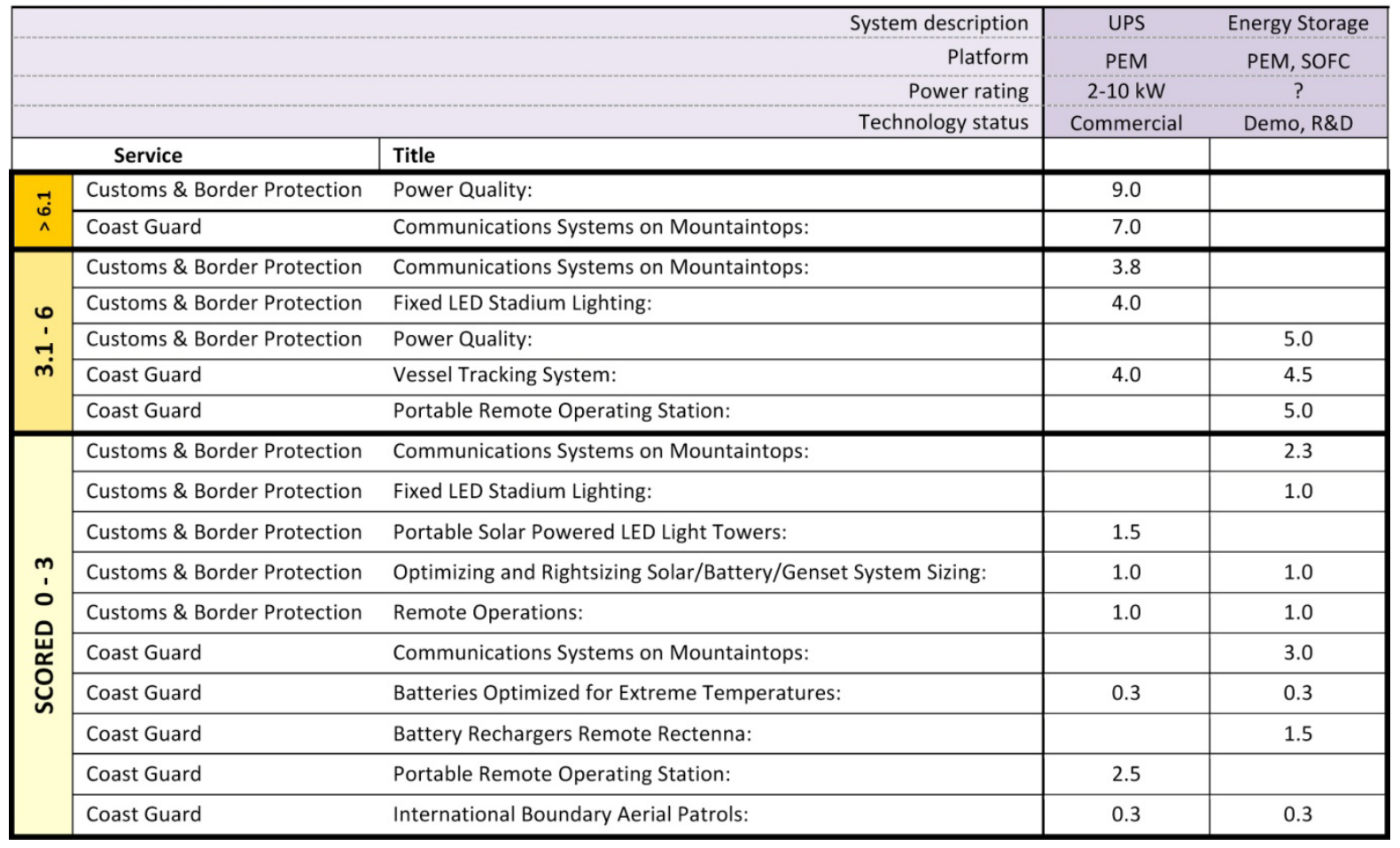


REMOTE APPLICATIONS

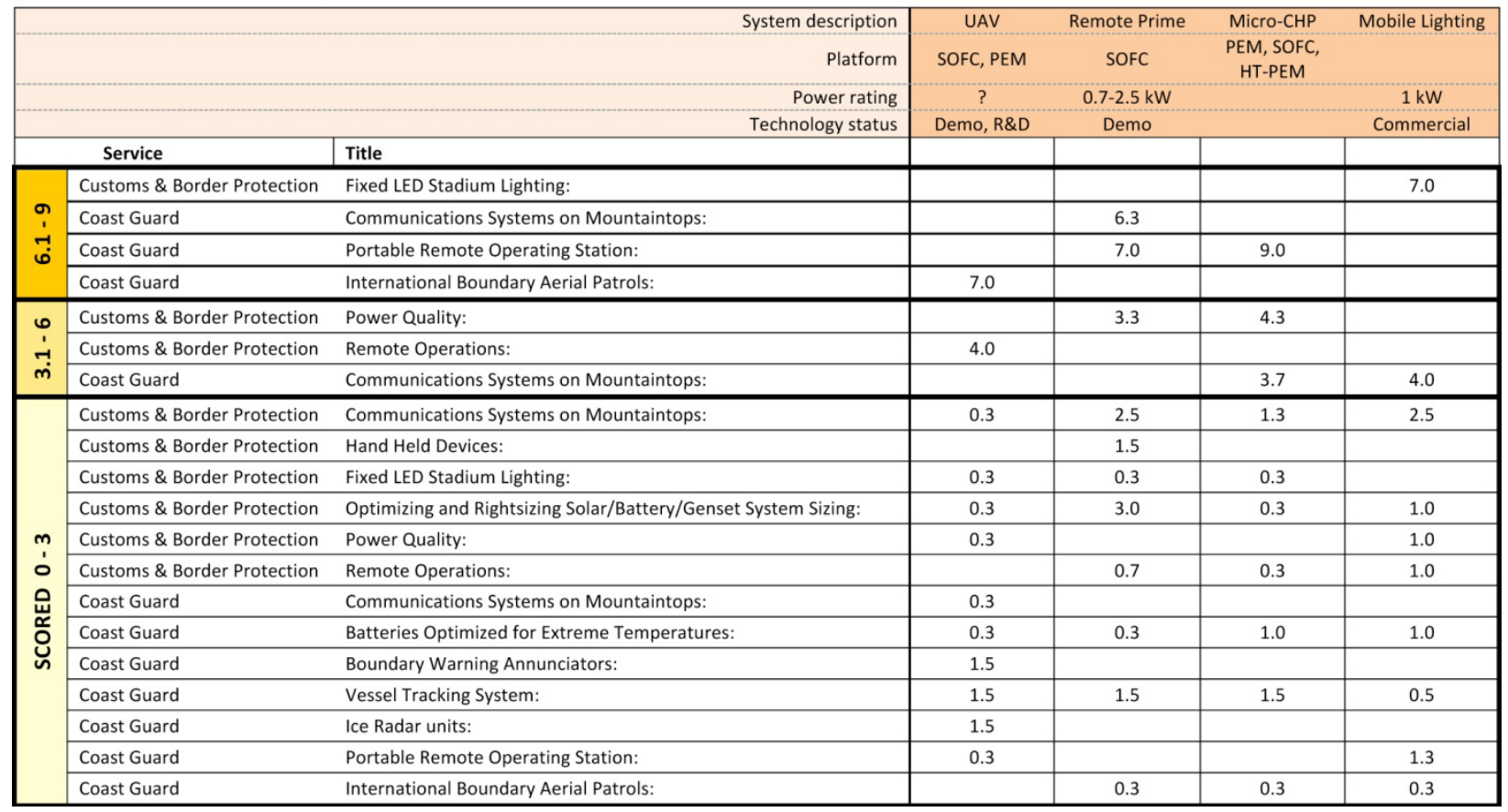

PORTABLE APPLICATIONS

\begin{tabular}{|c|c|c|c|c|c|c|c|}
\hline \multicolumn{3}{|r|}{ System description } & $\begin{array}{l}\text { Portable } \\
\text { Power }\end{array}$ & $\begin{array}{l}\text { Battery } \\
\text { Charger }\end{array}$ & $\begin{array}{l}\text { Portable } \\
\text { Power }\end{array}$ & Micro sofc & $\begin{array}{c}\text { Microbial } \\
\text { FC's }\end{array}$ \\
\hline \multicolumn{3}{|r|}{ Platform } & $\begin{array}{c}\text { DMFC, SOFC, } \\
\text { RMFC; } \\
\text { PEMFC }\end{array}$ & $\begin{array}{l}\text { DMFC, } \\
\text { PEMFC }\end{array}$ & \multicolumn{2}{|l|}{ PEM } & \\
\hline \multirow{2}{*}{\multicolumn{3}{|c|}{ Technology status }} & & $0.5-5 \mathrm{~kW}$ & $<2.5 \mathrm{~kW}$ & $50 \mathrm{~W}$ & \\
\hline & & & Demo, R\&D & $\begin{array}{l}\text { Commercial, } \\
\text { Demo, R\&D }\end{array}$ & Commercial & $R \& D$ & \\
\hline & Service & Title & & & & & \\
\hline \multirow{4}{*}{$\begin{array}{l}9 \\
\dot{a} \\
-1 \\
6\end{array}$} & Customs \& Border Protection & Hand Held Devices: & 9.0 & 9.0 & 7.0 & & \\
\hline & Customs \& Border Protection & Seismic Sensors: & & 9.0 & & & 9.0 \\
\hline & Customs \& Border Protection & Remote Operations: & 7.0 & 9.0 & & & \\
\hline & Coast Guard & International Boundary Aerial Patrols: & & & & & 7.0 \\
\hline \multirow{3}{*}{$\begin{array}{l}0 \\
\dot{1} \\
\dot{m}\end{array}$} & Customs \& Border Protection & Seismic Sensors: & 4.3 & & & & \\
\hline & Customs \& Border Protection & Remote Operations: & & & 6.0 & 4.5 & 4.0 \\
\hline & Coast Guard & Communications Systems on Mountaintops: & & & 3.3 & & \\
\hline \multirow{13}{*}{ 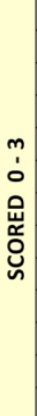 } & Customs \& Border Protection & Communications Systems on Mountaintops: & 1.0 & 0.8 & 2.5 & 0.3 & 0.3 \\
\hline & Customs \& Border Protection & Fixed LED Stadium Lighting: & 0.3 & & 0.3 & 0.5 & 0.3 \\
\hline & Customs \& Border Protection & Optimizing \& Rightsizing Solar/Battery/Genset System Sizing: & 0.3 & & 0.3 & 0.5 & 0.3 \\
\hline & Customs \& Border Protection & Power Quality: & 0.7 & 1.5 & 1.3 & 0.5 & 0.3 \\
\hline & Customs \& Border Protection & Seismic Sensors: & & & 0.5 & & \\
\hline & Coast Guard & Communications Systems on Mountaintops: & 1.3 & & 3.3 & 0.5 & 0.3 \\
\hline & Coast Guard & Batteries Optimized for Extreme Temperatures: & 1.0 & & 1.0 & 0.5 & 0.3 \\
\hline & Coast Guard & Battery Rechargers Remote Rectenna: & & & & & 3.0 \\
\hline & Coast Guard & Boundary Warning Annunciators: & & & & & 1.5 \\
\hline & Coast Guard & Vessel Tracking System: & 1.5 & & 1.5 & & 3.0 \\
\hline & Coast Guard & Ice Radar units: & & & & & 3.0 \\
\hline & Coast Guard & Portable Remote Operating Station: & 2.0 & & 2.0 & 0.5 & 0.3 \\
\hline & Coast Guard & International Boundary Aerial Patrols: & 1.3 & & 0.7 & 1.5 & \\
\hline
\end{tabular}

